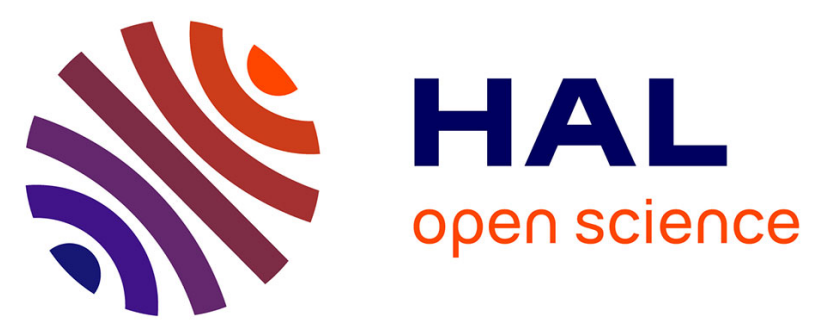

\title{
A Comparative Assessment Study of Known Small-Molecule Keap1-Nrf2 Protein-Protein Interaction Inhibitors: Chemical Synthesis, Binding Properties, and Cellular Activity
}

Kim Tran, Jakob Pallesen, Sara Solbak, Dilip Narayanan, Amina Baig, Jie Zang, Alejandro Aguayo-Orozco, Rosa Carmona, Anthony Garcia, Anders Bach

\section{- To cite this version:}

Kim Tran, Jakob Pallesen, Sara Solbak, Dilip Narayanan, Amina Baig, et al.. A Comparative Assessment Study of Known Small-Molecule Keap1-Nrf2 Protein-Protein Interaction Inhibitors: Chemical Synthesis, Binding Properties, and Cellular Activity. Journal of Medicinal Chemistry, 2019, 62 (17), pp.8028-8052. 10.1021/acs.jmedchem.9b00723 . hal-02474013

HAL Id: hal-02474013

https://hal-univ-rennes1.archives-ouvertes.fr/hal-02474013

Submitted on 21 Feb 2020

HAL is a multi-disciplinary open access archive for the deposit and dissemination of scientific research documents, whether they are published or not. The documents may come from teaching and research institutions in France or abroad, or from public or private research centers.
L'archive ouverte pluridisciplinaire HAL, est destinée au dépôt et à la diffusion de documents scientifiques de niveau recherche, publiés ou non, émanant des établissements d'enseignement et de recherche français ou étrangers, des laboratoires publics ou privés. 


\title{
A Comparative Assessment Study of Known Small-Molecule Keap1-Nrf2
}

\section{Protein-Protein Interaction Inhibitors: Chemical Synthesis, Binding Proper-}

\section{ties, and Cellular Activity}

\author{
Kim T. Tran, ${ }^{+, \|}$Jakob S. Pallesen, ${ }^{+, \|}$Sara M. $\varnothing$. Solbak, ${ }^{\dagger}$ Dilip Narayanan, ${ }^{\dagger}$ Amina Baig, ${ }^{\dagger}$ Jie Zang, ${ }^{\dagger}$ Alejandro \\ Aguayo-Orozco, ${ }^{\dagger, \#}$ Rosa M. C. Carmona, ${ }^{\dagger}$ Anthony D. Garcia, ${ }^{+, \infty, \ddagger}$ Anders Bach ${ }^{\dagger, *}$ \\ ${ }^{\dagger}$ Department of Drug Design and Pharmacology, Faculty of Health and Medical Sciences, University of \\ Copenhagen, Universitetsparken 2, DK-2100 Copenhagen, Denmark \\ ^École Nationale Supérieure de Chimie de Rennes, 11 Allée de Beaulieu, CS 50837, Rennes Cedex 735708 , \\ France
}

KEYWORDS: Kelch-like ECH-associated protein 1 (Keap1); nuclear factor erythroid 2-related factor 2 (Nrf2); small-molecule inhibitors; protein-protein interactions (PPIs); validation study

\begin{abstract}
Inhibiting the protein-protein interaction (PPI) between the transcription factor Nrf2 and its repressor protein Keap1 has emerged as a promising strategy to target oxidative stress in diseases, including CNS disorders. Numerous non-covalent small-molecule Keap1-Nrf2 PPI inhibitors have been reported to date, but many feature suboptimal physicochemical properties for permeating the blood-brain barrier, while others contain problematic structural moieties. Here, we present the first side-by-side assessment of all reported Keap1-Nrf2 PPI inhibitor classes using fluorescence polarization (FP), thermal shift assay (TSA), and surface plasmon resonance (SPR) - and further evaluate the compounds in an NQO1 induction cell assay and in counter tests for non-
\end{abstract}


specific activities. Surprisingly, half of the compounds were inactive or deviated substantially from reported activities, while we confirm the cross-assay activities for others. Through this study, we have identified the most promising Keap1-Nrf2 inhibitors that can serve as pharmacological probes or starting points for developing CNS active Keap1 inhibitors. 


\section{INTRODUCTION}

The nuclear factor erythroid 2-related factor 2 (Nrf2) transcription factor is a principal regulator of the cellular defense system against oxidative stress, promoting the transcription of an expansive set of antioxidant and cytoprotective enzymes, such as $\mathrm{NAD}(\mathrm{P}) \mathrm{H}$ :quinone oxidoreductase 1 (NQO1), heme oxygenase 1 (HO-1), and glutathione S-transferase for combating reactive oxidants and electrophilic species. ${ }^{1-3}$ Under quiescent conditions, $\mathrm{Nrf2}$ is kept at low concentrations by the cytosolic repressor protein Kelch-like ECH-associated protein 1 (Keap1), which associates with the Nrf2-ECH homology 2 (Neh2) domain of Nrf2 to facilitate cullin 3 (Cul3) mediated polyubiquitination and proteasomal degradation of Nrf2. ${ }^{2,4}$ Structurally, Keap1 consists of a broad complex, tramtrack, and bric-à-brac (BTB) domain, an intervening region (IVR), and a Kelch domain. It has been proposed that a Keap1 homodimer, via its two Kelch domains, binds a single Nrf2 peptide at a high-affinity ETGE-site and low-affinity DLG-site contained in the Neh2 domain. This creates a fixed spatial alignment of Nrf2 that allows polyubiquitination by the BTB domain-docked Cul3 to take place. ${ }^{5-8}$ Under oxidative or electrophilic assault, specific sensor cysteine residues on the IVR and/or BTB domains of Keap1 are modified to disrupt this oligomeric Nrf2-Keap1-Cul3 complex, thus prohibiting polyubiquitination. 5, 9, 10 In combination with de novo synthesis, Nrf2 then accumulates and translocates into the nucleus to transactivate a large assembly of antioxidant response element (ARE)-dependent enzymes that can reestablish redox homeostasis. ${ }^{1,11,12}$

Nrf2 upregulation by Keap1 inhibition has been proposed as a potential therapeutic strategy to target oxidative stress-involved pathologies. ${ }^{10,}{ }^{13-15}$ Importantly, Nrf2 activation by genetic knock-out studies and pharmacological Keap1 inhibition has shown encouraging neuroprotective effects in animal models of cerebral ischemia, hemorrhagic stroke, traumatic brain injury, and chronic neurodegenerative disorders. ${ }^{16-20}$

An increasingly prevalent strategy to upregulate $\mathrm{Nrf2}$ is to competitively disrupt the protein-protein interaction (PPI) between the Keap1 Kelch domain and the Nrf2 Neh2 peptide motifs. ${ }^{21,}{ }^{22}$ Early research focused on developing truncated peptide inhibitors containing the high-affinity ETGE-sequence of the Neh2 domain e.g. 9mer peptides 1 and $\mathbf{2}$ with submicromolar binding affinities to the Keap1 Kelch domain (Figure 1A). ${ }^{23,}{ }^{24}$ Although recent research has attempted to address their inherent shortcomings by e.g. macrocyclization, ${ }^{25}$ pep- 
tide inhibitors generally suffer from low cellular permeability, stability, and activity. The Keap1-Nrf2 interaction stands out from classical PPIs by having a relatively small interaction surface $\left(550-780 \AA^{2}\right)$ and concave binding pocket. ${ }^{7}$ Furthermore, the pocket features five interconnected epitopes (P1-P5), of which at least P1, P4, and P5 are considered hot spots for ligand-binding (Figure 1B)..$^{22,26,27}$

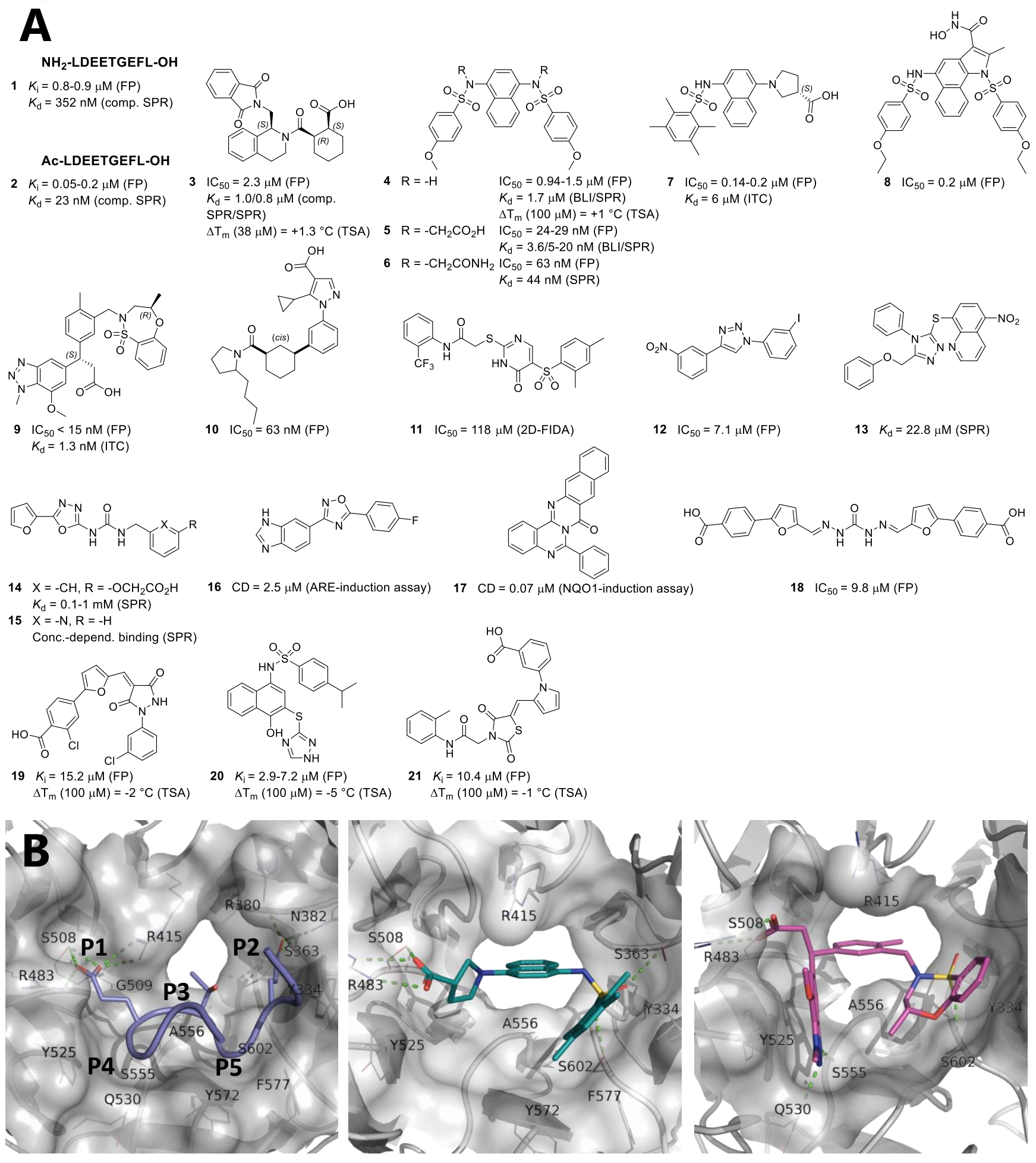


Figure 1. (A) Structure and activities of all known non-covalent small-molecule Keap1-Nrf2 PPI inhibitors (for inhibitors from larger SAR-studies only representative compounds are shown) and representative peptide inhibitors. 1 and 2: Inoyama et al. ${ }^{28}$, Hancock et al. ${ }^{24} ; 3$ : Hu et $a .^{29}$, Inoff et $a .^{30}$, Bresciani et al. ${ }^{31}$, PubChem ${ }^{32} ; 4$ : Marcotte et $a l .{ }^{33}$, Jiang et $a l .{ }^{22}$, Jain et $a l .{ }^{34}$, Zhuang et $a l .{ }^{35} ; 5$ : Jiang et $a l .{ }^{22}$; Jain et al. ${ }^{34}$; Bresciani et al. ${ }^{31} ; 6$ : Jain et $a I^{34}$; 7: Winkel et al. ${ }^{36}$, Szill et $a .^{37} ;$ 8: Yasuda et al. ${ }^{38} ;$ 9: Davies et al. ${ }^{27} ; 10$ : Callahan et al. ${ }^{39}$; 11: Marcotte et al. ${ }^{33} ;$ 12: Bertrand et al. ${ }^{40} ; 13:$ Kazantsev et $a .^{41} ; 14:$ Satoh et al. ${ }^{42} ; 15:$ Shimozono et al. ${ }^{43} ; 16:$ Xu et al. ${ }^{44} ; 17$ : Ghorab et al. ${ }^{45}$; 18: Sun et al. ${ }^{46} ;$ 19-21: Zhuang et al. ${ }^{35}$ Comp. SPR: Competitive SPR. BLI: Bio-layer interferometry. ITC: Isothermal titration calorimetry. 2D-FIDA: Two-dimensional fluorescence intensity distribution analysis. CD: Concentration inducing a two-fold increase in response. (B) X-ray structures of the Keap1 Kelch domain in complex with 1 (left, purple, PDB code 1X2R), 7 (middle, turquoise, PDB code 5CGJ), and 9 (right, violet, PDB code 5FNU). The sub-pockets P1-P5 have been indicated for the Kelch domain in complex with 1. Figures were made in PyMOL.

Several non-covalent small-molecule Keap1 inhibitors have been reported, many of which exhibit promising in vitro binding affinities to Keap1, are able to displace Neh2 peptides in competition assays, and/or have demonstrated downstream cellular effects (Figure 1A)..$^{22,24,27-46}$ Additionally, a number of inhibitors (3, 4, 6, 7, 9, 11, and 14) have been confirmed by X-ray crystallography to bind the Kelch domain (see examples in Figure 1B). ${ }^{10}$ However, since the Kelch binding pocket is still rather large compared to classical enzyme or receptor pockets and contains multiple arginine residues (Figure 1B), bulky ligands featuring carboxylic acids have been enriched in medicinal chemistry programs. ${ }^{26}$ These features generally result in poor cell permeability and might explain the discrepancy between binding affinity and cell activity observed for e.g. compound 5. ${ }^{22,27}$ In relation to CNS drug discovery, large molecular weight (>470 Da), large topological polar surface area (tPSA $>90 \AA ̊$ ), numerous hydrogen bond donors ( $\mathrm{HBD}>2$ ), and the presence of carboxylic acid groups generally impede blood-brain barrier (BBB) penetration. ${ }^{47,} 48$ The CNS permeability has been experimentally tested on a few 
Keap1 inhibitors ( 3 and $\mathbf{1 3}$ ) but with discouraging results, ${ }^{30,41}$ and based on their low CNS multiparameter optimization (CNS MPO) scores, ${ }^{47,48}$ the other reported inhibitors would not be expected to pass the BBB either. ${ }^{10}$

One strategy for addressing the issues listed above is to optimize known Keap1 inhibitors for cell and CNS activity. To facilitate such efforts, we found it crucial to verify the medicinal chemistry data of the reported inhibitors. In general, concerns have been raised on the low reproducibility in chemical as well as biological research, ${ }^{49-51}$ and specifically, we suspect some of the compounds identified in biochemical assays without confirmatory biophysical binding data are artifacts. Indeed, some of the inhibitors seen in Figure 1A contain pan-assay interference compounds (PAINS) substructures or other problematic structural elements that make them unattractive in drug development. ${ }^{52,53}$ Yet, uncritical use of PAINS substructure filters is fraught with risk and might inappropriately exclude a viable starting point for optimization. ${ }^{54}$

In this comparative assessment study, we carefully scrutinize the scientific data on all known smallmolecule Keap1 inhibitor classes that we are aware of (3-21, Figure 1A). We describe the challenges and reproducibility issues in synthesizing relevant inhibitors, and we establish whether the inhibitors bind to the Keap1 Kelch domain using the three orthogonal assays, fluorescence polarization (FP), thermal shift assay (TSA), and surface plasmon resonance (SPR). We also evaluate the compounds in an NQO1 induction cell assay. This allows for a direct side-by-side comparison of the inhibitors, which have otherwise been tested in various assays and different laboratories. Finally, we tested the compounds for common liabilities such as covalent reactivity, redox activity, and aggregation. Hereby, we elucidate which of the published Keap1 inhibitors can serve as reliable control compounds in future research, and we identify those most suitable as starting points for further drug discovery efforts, including development of CNS active Keap1 inhibitors. 


\section{RESULTS}

\section{Selection and synthesis of known small-molecule Keap1-Nrf2 PPI inhibitors.}

Based on a recent literature investigation, ${ }^{10}$ we commenced this study by including all the small-molecules we know of and that have been reported to non-covalently inhibit the Keap1-Nrf2 PPI in competitive assays (FP or 2D-FIDA) (3-12 and 18-21) or to directly bind the Kelch domain in biophysical assays (SPR) (13-15). For larger compound series, we chose the most potent or well-characterized inhibitors as representatives. We also included compounds 16 and 17, which show downstream Nrf2-dependent gene activation, ${ }^{44,45}$ but for which direct inhibition or binding data have not been provided. ${ }^{10}$ Compound 16 was interesting due to its high CNS drug-likeness (CNS MPO scores $~ 5$ ) and structural similarity with 12, while compound 17 was included due to its high reported cellular activity and since non-covalent binding to the Kelch domain has been suggested by molecular docking. ${ }^{45}$ Finally, the two well-characterized peptides $\mathbf{1}$ and $\mathbf{2}$ were included as controls, leading to a total list of 21 compounds (Figure 1A).

The 21 compounds were either purchased $(\mathbf{1}, \mathbf{2}, \mathbf{1 3}, \mathbf{1 5}$, and 18-21) or synthesized, generally following previously reported procedures. ${ }^{22,} 27,29,34,36,38-40,42,44,45,55-58$ Compounds $\mathbf{9}, \mathbf{1 2}, \mathbf{1 4}$, and $\mathbf{1 6}$ were generated with no or only small changes from literature protocols and in acceptable yields (Supporting Information Scheme S1-4), while the syntheses of $\mathbf{3}, \mathbf{4 - 8}, \mathbf{1 0}, \mathbf{1 1}$, and $\mathbf{1 7}$ were more challenging, as described next.

The previously reported asymmetric protocol ${ }^{30}$ for synthesizing the active (SRS)-stereoisomer $\mathbf{3}$ was attempted but found laborious. The synthesis is lengthy (11 steps) and includes synthetic steps, such as a reduction of an aromatic ketone and an $\mathrm{N}$-benzyl deprotection step, which were difficult in our hands. We found the initially reported non-enantioselective procedure ${ }^{29}$ with an end-stage resolution by chiral HPLC to be a more feasible route giving higher yields ( $7 \%$ vs. $<0.1 \%$ overall yield) in fewer steps ( 5 steps, Scheme 1 ). Achieving the correct (SRS)-stereoisomer $\mathbf{3}$ was confirmed by testing the biological activities of all four isolated stereoisomers, since 3 was reported to be at least a 100-fold more active than the other three isomers. ${ }^{29}$ 


\section{Scheme 1. Synthesis of compound $3^{a}$}

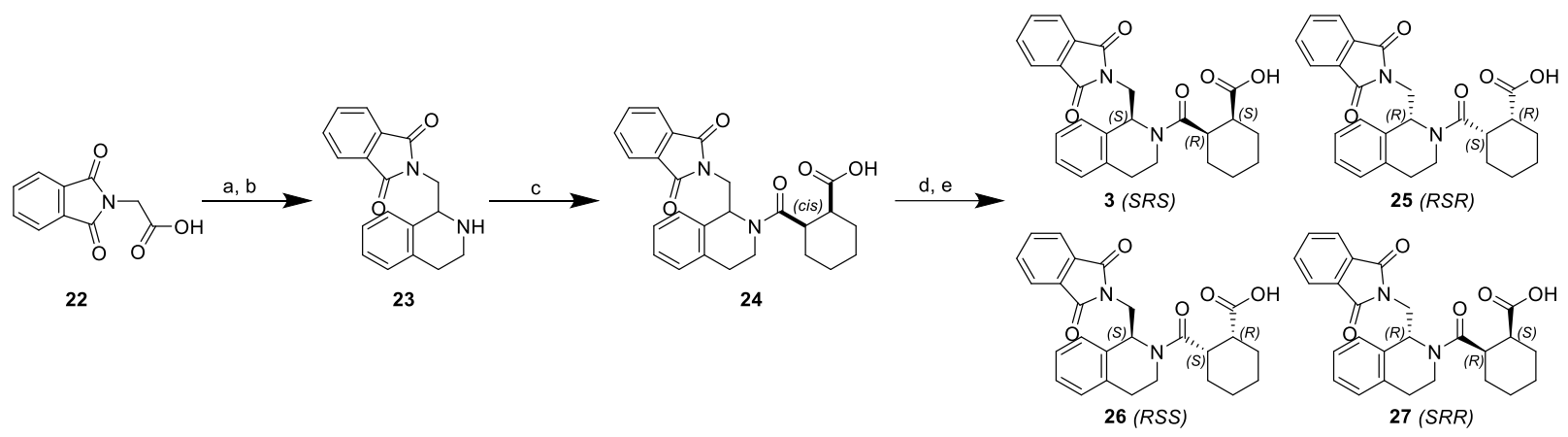

${ }^{a}$ Conditions: (a) 2-phenylethan-1-amine, $\mathrm{POCl}_{3}, \mathrm{MeCN}, \mathrm{RT}, 85^{\circ} \mathrm{C}, 46 \%$; (b) $\mathrm{NaBH}_{3} \mathrm{CN}, 4 \mathrm{M} \mathrm{HCl}$ in 1,4-dioxane, $\mathrm{MeOH}, \mathrm{RT}, 1 \mathrm{~h}, 76 \%$; (c) (3aR,7aS)-hexahydroisobenzofuran-1,3-dione, $p$-Xylene, $50{ }^{\circ} \mathrm{C}, 1 \mathrm{~h}, \mathrm{RT}, 24 \mathrm{~h}$, yield ND; (d) flash silica chromatography; (e) chiral separation on Chiralcel OD, 19\% over step c-e.

The family of 1,4-diaminonaphthalene compounds 4-8 were synthesized divergently from a common 4nitronaphthalen-1-amine intermediate 29 following previously reported procedures (Scheme 2). ${ }^{22,34,36,38,56} \mathrm{~A}$ key issue with these syntheses lies in the poor stability of the 1,4-diamino intermediates $\mathbf{3 0}$ and $\mathbf{3 3}$, which were observed to rapidly degrade, presumably through oxidation; this might explain the reproducibility issues in terms of yields, i.e. the previously reported yield for the synthesis of $4(64 \%)$ could not be replicated here (13$23 \%$ ), which also applies for compound 7 (overall yield of $15 \%$ vs. literature yield of $35 \%$ ). To minimize degradation of the intermediates $\mathbf{3 0}$ and $\mathbf{3 3}$, workup of the reactions were carried out relatively quickly, purifications or characterizations were not performed and the following reactions conducted immediately after isolation of the compound. 
Scheme 2. Synthesis of compounds $4-8^{a}$

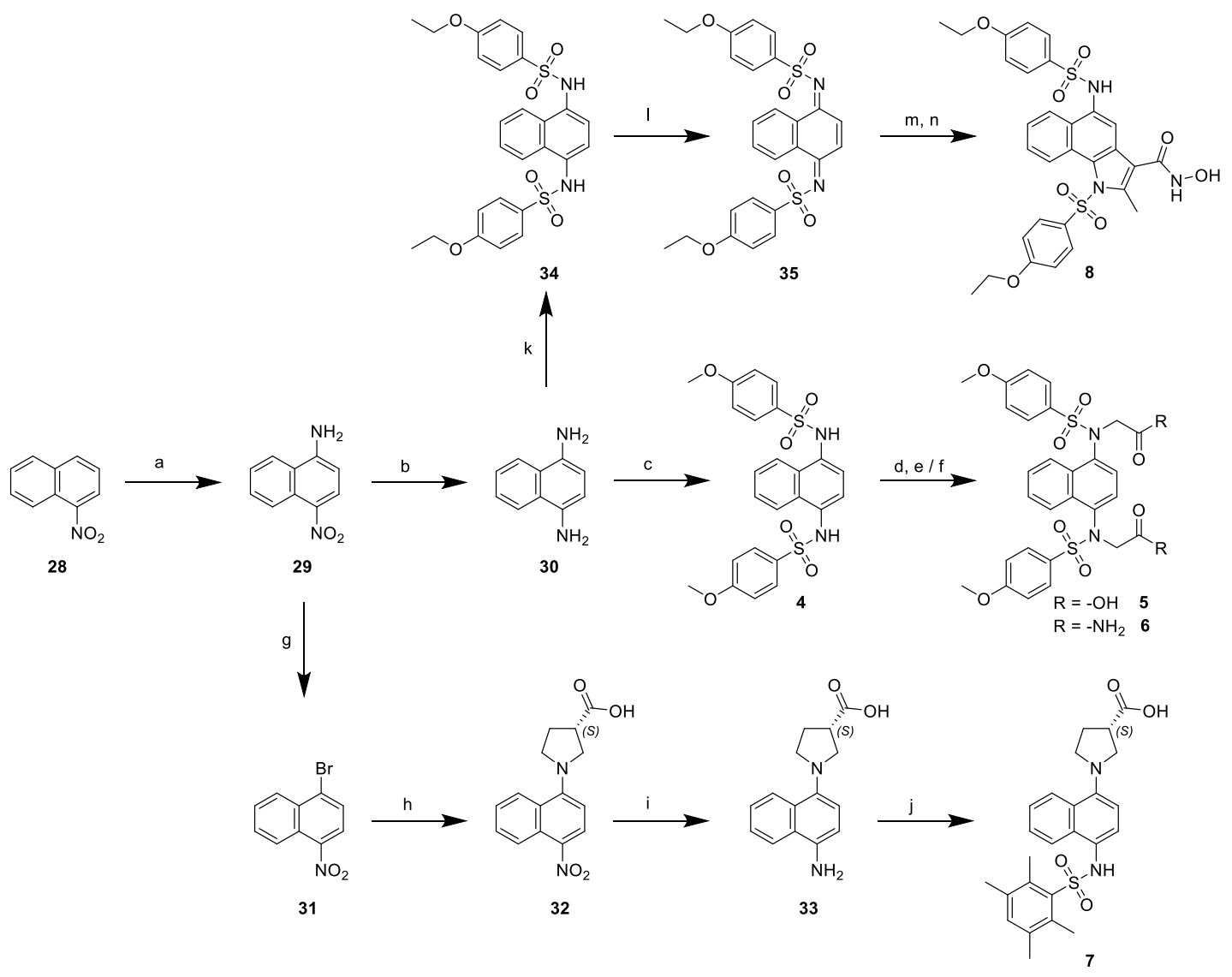

${ }^{a}$ Conditions: (a) $\mathrm{NH}_{2} \mathrm{OH} \cdot \mathrm{HCl}, \mathrm{KOH}, \mathrm{EtOH} / \mathrm{MeOH}, 60{ }^{\circ} \mathrm{C}, 2 \mathrm{~h}, 55 \%$; (b) Pd/C, $\mathrm{H}_{2}$ (1 atm, balloon), EtOH, RT, 2 h, yield ND; (c) 4-methoxybenzenesulfonyl chloride, pyridine, toluene, $100{ }^{\circ} \mathrm{C}, 2 \mathrm{~h}, 13-23 \%$ over 2 steps; (d) ethyl bromoacetate, $\mathrm{K}_{2} \mathrm{CO}_{3}$, DMF, RT, $3 \mathrm{~h}, 90 \%$; (e) $\mathrm{NaOH}, \mathrm{MeOH} / \mathrm{H}_{2} \mathrm{O}, 65^{\circ} \mathrm{C}, 3 \mathrm{~h}, 67 \%$; (f) 2-bromoacetamide, $\mathrm{K}_{2} \mathrm{CO}_{3}$, DMF, RT, 5 days, 29\%; (g) $t$-BuONO, $\mathrm{CuBr}_{2}, \mathrm{TBAB}$, camphorsulfonic acid, $\mathrm{MeCN}, 60{ }^{\circ} \mathrm{C}, 24 \mathrm{~h}, 83 \%$; (h) (S)pyrrolidine-3-carboxylic acid, $\mathrm{Cul}, \mathrm{K}_{2} \mathrm{CO}_{3}, \mathrm{DMF}, \mathrm{Ar}, 150^{\circ} \mathrm{C}, 24 \mathrm{~h}, 96 \%$; (i) Pd/C, $\mathrm{H}_{2}$ (2 bar), MeOH, EtOAc, $\mathrm{H}$-Cube Mini Plus ${ }^{\mathrm{TM}}$, RT, $1.0 \mathrm{~mL} / \mathrm{min}$, yield ND; (j) 2,3,5,6-tetramethylbenzene-1-sulfonyl chloride, pyridine, DCM, RT, 16 h, 16\% over two steps; (k) 4-ethoxybenzenesulfonyl chloride, pyridine, DCM, RT, 25 min, 48\%; (I) ceric ammonium nitrate, MeCN, RT, 18 min, 89\%; (m) ethyl acetoacetate, $\mathrm{Et}_{3} \mathrm{~N}$, toluene, RT, 2 h, 48\%; (n) $\mathrm{NH}_{2} \mathrm{OH} \cdot \mathrm{HCl}$, $\mathrm{AcOH}, \mathrm{H}_{2} \mathrm{O}, 80^{\circ} \mathrm{C}, 2 \mathrm{~h}, 47 \%$.

Compound 10 was synthesized according to the reported procedure ${ }^{39,57}$ with some adjustments (Scheme 3). The synthetic route relies on a central Suzuki-Miyaura cross-coupling between an enol triflate $\mathbf{3 8}$ and an aryl 
boronate ester building block $\mathbf{4 1}$ as the crucial carbon skeleton-building step. Synthesis of the enol triflate using the one-step NaHMDS-mediated enolization/PhNTf 2 -induced trapping procedure reported in the patent application $^{39}$ was not efficient in our hands, giving low yield (43\% vs. $88 \%$ reported in literature ${ }^{39}$ ) and significant byproduct formation. We found that using a freshly-made LiHMDS as an alternative base gave a cleaner reaction and excellent yield (quantitative). The converging SM reaction step between $\mathbf{3 8}$ and $\mathbf{4 1}$ gave several wellknown by-products, including the boronic acid, aryl boronate homo-coupling product and protodeboronation product, but could still afford the desired cross-coupling product $\mathbf{4 2}$ in good yield (69\% vs. 33\% reported in literature ${ }^{39}$ ). Catalytic hydrogenation to deprotect the carboxylic acid and reduce the alkene double bond diastereoselectively furnished only the cis-cyclohexane $\mathbf{4 3}$ in accordance with literature; ${ }^{39}$ this was revealed by nuclear Overhauser effect (NOE) NMR (Supporting Information Figure S1). This facial selectivity can be explained by a steric directing effect of the carboxybenzyl group. The cyclohexane carboxylic acid of $\mathbf{4 3}$ was finally coupled with 2-butylpyrrolidine and the pyrazole carboxylic acid deprotected to give $\mathbf{1 0}$ as a mixture of four stereoisomers. Attempted separation of the two diastereoisomers by preparative HPLC was unsuccessful. In the patent application, purification by HPLC is reported to give two different fractions, each containing all four stereoisomers in slightly different proportions, of which one was directly tested as a mixture. ${ }^{39}$ Having this literature result as a reference point, we did not proceed with further purification of 10.

\section{Scheme 3. Synthesis of compound $10^{a}$}

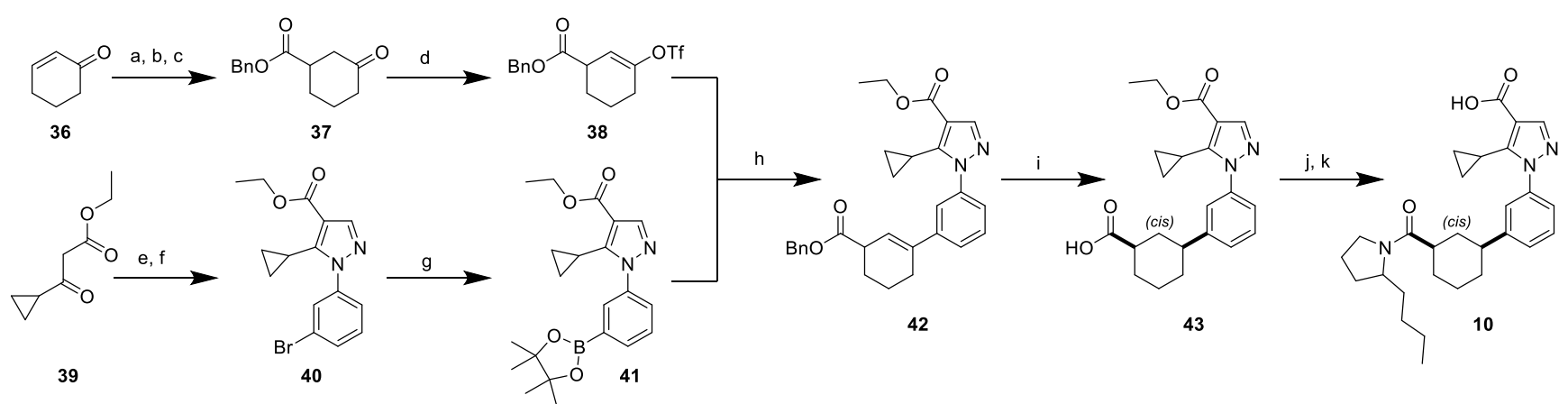

${ }^{a}$ Conditions: (a) $\mathrm{Cs}_{2} \mathrm{CO}_{3}, \mathrm{TMS}-\mathrm{CN}, \mathrm{H}_{2} \mathrm{O} / 1$,4-dioxane, $100{ }^{\circ} \mathrm{C}, 2 \mathrm{~h}, 82 \%$; (b) $12 \mathrm{M}$ aq. $\mathrm{HCl}, 80{ }^{\circ} \mathrm{C}, 45 \mathrm{~min}, 44 \%$; (c) $\mathrm{BnBr}, \mathrm{DBU}, \mathrm{MeCN}, \mathrm{RT}, 1 \mathrm{~h}, 50 \%$; (d) LiHMDS, PhNTf 2 , THF, Ar, $-78^{\circ} \mathrm{C}-\mathrm{RT}, 16 \mathrm{~h}$, quantitative; (e) DMF-dimethyl acetal, $\mathrm{MW}, 130{ }^{\circ} \mathrm{C}, 15 \mathrm{~min}$ (telescoping); (f) 3-bromophenylhydrazine $\cdot \mathrm{HCl}, \mathrm{Et}{ }_{3} \mathrm{~N}, \mathrm{EtOH}, \mathrm{RT}, 18 \mathrm{~h}$, quantitative; 
(g) $\mathrm{B}_{2} \mathrm{pin}_{2}, \mathrm{Pd}(\mathrm{dppf}) \mathrm{Cl}_{2}, \mathrm{KOAc}, 1$,4-dioxane, reflux, 4 h, 76\%; (h) $\mathrm{Pd}\left(\mathrm{PPh}_{3}\right)_{4}, \mathrm{Na}_{2} \mathrm{CO}_{3}, \mathrm{EtOH} / \mathrm{H}_{2} \mathrm{O} /$ toluene, Ar, reflux, 3 h, 69\%; (i) Pd/C, H2 (1 atm, balloon), EtOH, RT, 24 h, quantitative; (j) 2-butylpyrrolidine hydrochloride, HATU, DIPEA, DCM, RT, 18 h, 44\%; (k) NaOH, $i-\mathrm{PrOH} / \mathrm{H}_{2} \mathrm{O}, \mathrm{RT}, 72$ h, $41 \%$.

The synthesis of $\mathbf{1 1}$ has previously not been reported. The synthesis was carried out by utilizing 5-bromo1,3-dimethyluracil 44 as the central building block (Scheme 4). A microwave-assisted nucleophilic aromatic substitution $\left(\mathrm{S}_{N} \mathrm{Ar}\right)$ procedure by Fang et $a .^{59}$ was employed to obtain the sulfide intermediate 45 . Following oxidation to sulfone $\mathbf{4 6}$, the 1,3-dimethyluracil core was converted into thiouracil $\mathbf{4 7}$ upon treatment with thiourea under basic conditions, employing a procedure by Hirota et al. ${ }^{60}$ Finally, an end-stage alkylation with alkyl bromide 49 (obtained from treating 2-trifluoromethylaniline $\mathbf{4 8}$ with bromoacetyl bromide) gave target molecule 11.

\section{Scheme 4. Synthesis of compound $11^{a}$}

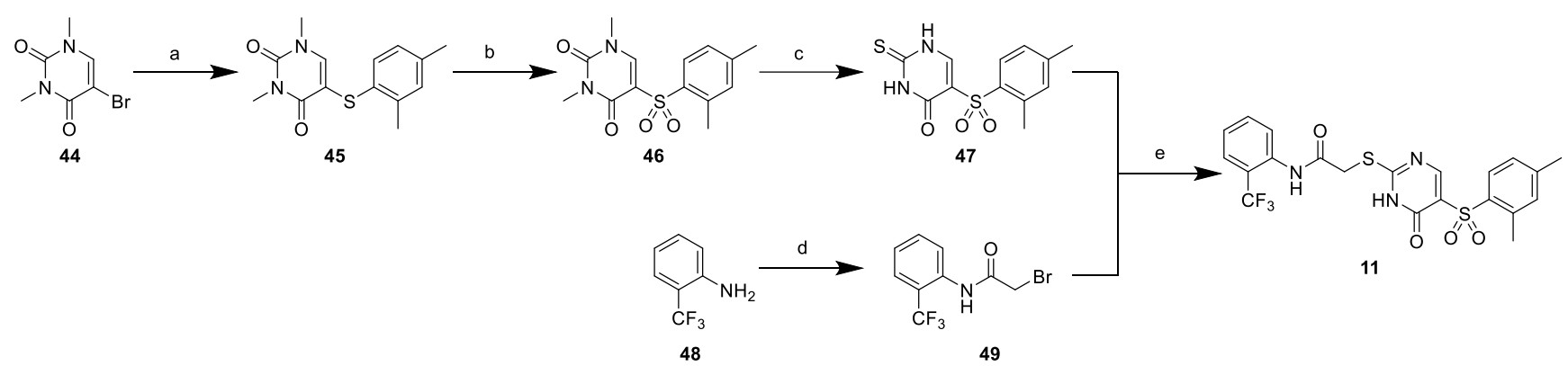

${ }^{a}$ Conditions: (a) Sodium 2,4-dimethylbenzenethiolate, NMP, MW, $130{ }^{\circ} \mathrm{C}, 10 \mathrm{~min}, 62 \%$; (b) $\mathrm{mCPBA}, \mathrm{DCM}, 0{ }^{\circ} \mathrm{C}-$

RT, 3 h, 71\%; (c) $\left(\mathrm{NH}_{2}\right)_{2} \mathrm{CS}, \mathrm{NaOEt}, \mathrm{EtOH}, \mathrm{Ar}, 100{ }^{\circ} \mathrm{C}$ (pressure vial), 16 h, 40\%; (d) 2-bromoacetyl bromide, Et $3 \mathrm{~N}$, 1,4-dioxane, $\mathrm{N}_{2}, 0^{\circ} \mathrm{C}-\mathrm{RT}, 2 \mathrm{~h}, 89 \%$; (e) $\mathrm{Et}_{3} \mathrm{~N}, \mathrm{DMF}, 80^{\circ} \mathrm{C}, 1.5 \mathrm{~h}, 55 \%$.

The previously described one-step procedure by Ghorab et al. for synthesizing the quinazoline compound $\mathbf{1 7}$ by simply refluxing $\mathbf{5 0}$ and $\mathbf{5 1}$ in DMF for $24 \mathrm{~h}^{45}$ was futile in our hands with no observed cyclization of the intermediate $S_{N} A r$ product 52. Instead, we conceived a two-step procedure (Scheme 5) consisting firstly of a condensation of $\mathbf{5 0}$ and $\mathbf{5 1}$ by refluxing in neat acetic acid followed by an acetic anhydride-mediated ring- 
closure to afford the target molecule in a good overall yield (75\%) comparable to what was reported for the one-step procedure $(69 \%){ }^{45}$

\section{Scheme 5 . Synthesis of compound $17^{a}$}

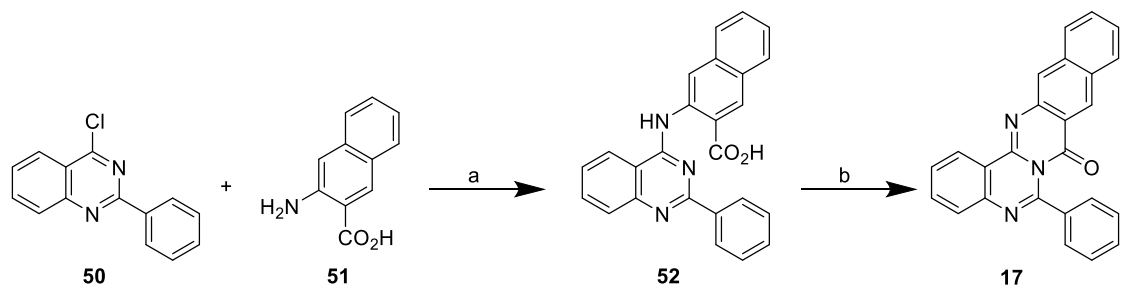

${ }^{a}$ Conditions: (a) $\mathrm{AcOH}$, reflux $1 \mathrm{~h}, 91 \%$; (b) $\mathrm{Ac}_{2} \mathrm{O}$, reflux, $1 \mathrm{~h}, 82 \%$.

All compounds were thoroughly quality controlled by LC-MS and NMR, and the DMSO- $d_{6}$ stocks were concentration-determined by quantitative $1 \mathrm{D}^{1} \mathrm{H}$ NMR (qHNMR) prior to assaying and checked for stability by LCMS during or after testing.

\section{Inhibition activity in competitive FP assay.}

FP is one of the most widespread fluorescence-based technique employed to identify modulators of PPIs ${ }^{61}$ and is also the most commonly used assay for Keap1-Nrf2 PPI inhibitors; ${ }^{26}$ indeed, most of the compounds shown in Figure $1 \mathbf{A}$ have been tested in an FP assay. ${ }^{22,} 24,27,28,30,34-38,40,46,62$ Here, we established the FP assay using both Cy5 and FAM as fluorophores attached $\mathrm{N}$-terminally to a 9mer peptide-moiety of $\mathrm{Nrf2}$ with the sequence LDEETGEFL-NH2. Although fluorescein has been used mostly to label Nrf2 peptides, readouts with red-shifted fluorophores such as Cy5 are generally more advantageous in terms of reducing the occurrence of fluorescence interferences. ${ }^{63,64}$ The resulting peptide probes (here designated Cy5-Nrf2 and FAM-Nrf2) gave $K_{d}$ values of 7.5-13.6 nM when saturated by Keap1 (Supporting Information Figure S2A-C), which are similar to literature values (e.g. $11.4 \mathrm{nM}$ reported by Inoyama et al. for Cy5-LDEETGEFL-NH $\mathrm{N}_{2}$ and $51.0 \mathrm{nM}$ reported by Hancock et al. for the comparable peptide probe FAM-LDEETGEFLP-OH). ${ }^{24,28}$ 
Compounds 1-11 all showed robust inhibition (Figure $\mathbf{2 A}$ ) with $K_{\mathrm{i}}$ values correlating with literature (Figure 1 vs. Table 1). ${ }^{22,24,27,28,30,34,36,37,39}$ Only compounds 8 and $\mathbf{1 1}$ showed some deviations from the literature $\left(K_{\mathrm{i}}=\right.$ $0.0021 \mu \mathrm{M}$ vs. $\mathrm{IC}_{50}=0.20 \mu \mathrm{M}^{38}$ and $K_{\mathrm{i}}=2.8 \mu \mathrm{M}$ vs. $\mathrm{IC}_{50}=118 \mu \mathrm{M}^{33}$, respectively). For compound 8 , this difference can be explained by a high protein-to-probe concentration ratio in the reported FP assay (250 nM Keap1 to $10 \mathrm{nM}$ probe) compared to our conditions (14 nM Keap1 to $3 \mathrm{nM}$ probe); this is despite using the same peptide probe. ${ }^{38}$ Thus, considering the affinity of the probe, such conditions would give rise to a significantly higher $I_{50}$ value than the $K_{\mathrm{i} .}{ }^{38,65} \mathrm{In}$ fact, using the reported protein and probe concentrations and assuming a $K_{\mathrm{d}}$ of $10 \mathrm{nM}$ for the probe, a $K_{\mathrm{i}} \approx 2 \mathrm{nM}$ can be calculated from their measured $\mathrm{IC}_{50}$ value of $0.20 \mu \mathrm{M}$, which is in line with our result. For compound $\mathbf{1 1}$, the $\mathrm{IC}_{50}$ value was derived from a different assay (2D-FIDA) ${ }^{33}$ and might therefore not be comparable with our result. Another source of error could be ligand concentrations, but noticeably, we here applied qHNMR to accurately quantify our stocks.
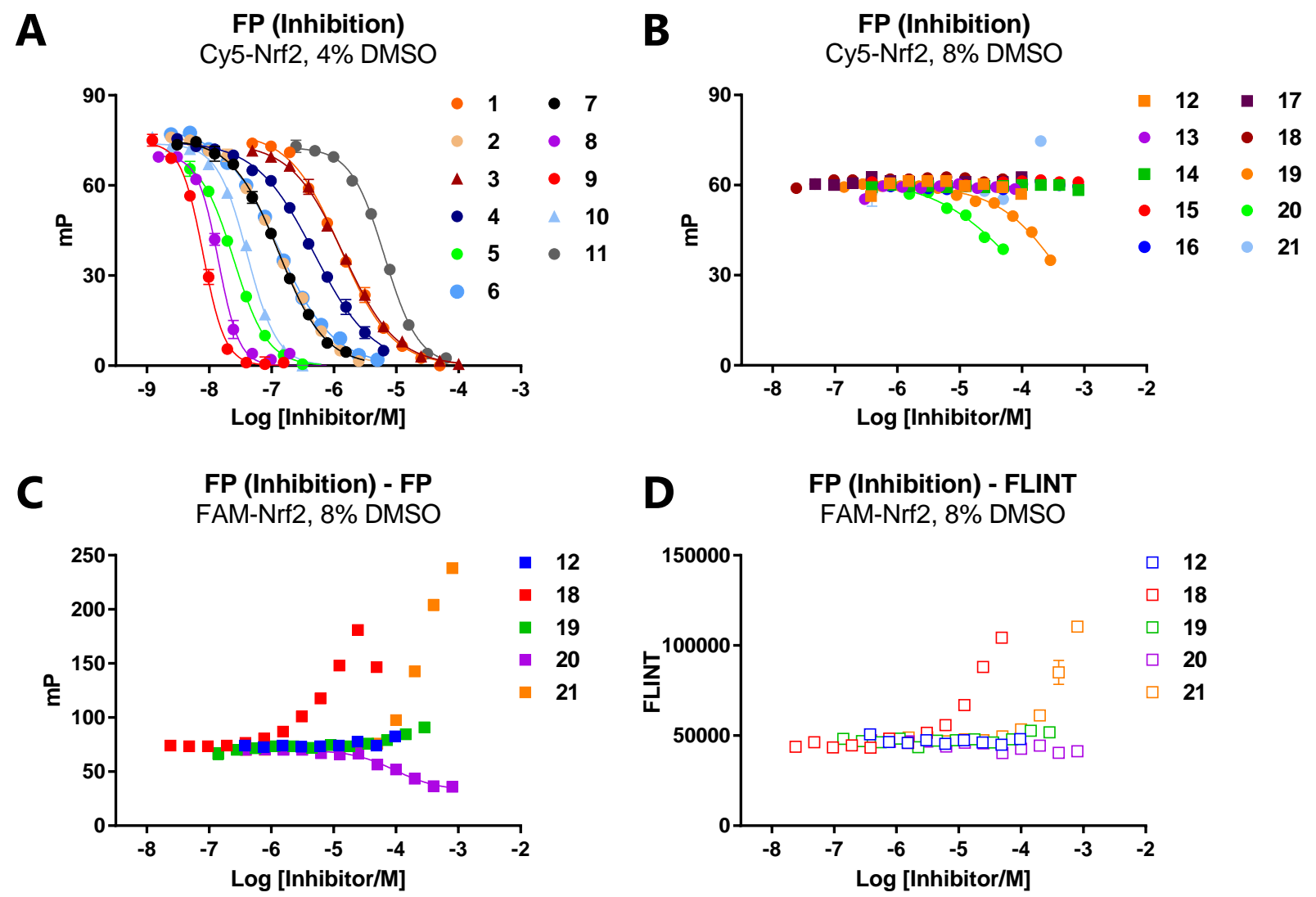

Figure 2. Results from the competitive FP assay. Concentration-response curves for compounds 1-11 (A) and 12-21 (B) using the Cy5-Nrf2 probe. (C) Concentration-response curves for compounds $\mathbf{1 2}$ and 18-21 using the 
FAM-Nrf2 probe and (D) the total fluorescence intensity (FLINT) measured in these experiments. Representative curves of $\geq 3$ individual measurements are here shown (as means of duplicates \pm SEM).

Table 1. Activities of known small-molecule Keap1 inhibitors by FP (Cy5-Nrf2 probe), TSA, and SPR. ${ }^{a}$

\begin{tabular}{|c|c|c|c|c|}
\hline Compound & $\mathrm{FP}\left(K_{\mathrm{i}} / \mu \mathrm{M}\right)$ & $\mathrm{TSA}\left(\mathrm{EC}_{50} / \mu \mathrm{M}\right)$ & $\operatorname{TSA}\left(\Delta \mathrm{T}_{\mathrm{m}}-\mathrm{max} /{ }^{\circ} \mathrm{C}\right)$ & $\operatorname{SPR}\left(K_{\mathrm{d}} / \mu \mathrm{M}\right)$ \\
\hline 1 & $0.54 \pm 0.009$ & $25 \pm 1$ & $9.4 \pm 0.2$ & $4.2 \pm 0.5$ \\
\hline 2 & $0.051 \pm 0.0002$ & $13 \pm 0.6$ & $14 \pm 0.1$ & $0.74 \pm 0.3$ \\
\hline 3 & $0.56 \pm 0.03$ & $26 \pm 1$ & $12 \pm 0.2$ & $2.4 \pm 1.0$ \\
\hline 4 & $0.25 \pm 0.02$ & $5.8 \pm 0.4$ & $4.2 \pm 0.3$ & $0.37 \pm 0.09$ \\
\hline 5 & $0.0061 \pm 0.0002$ & $5.9 \pm 0.6$ & $22 \pm 0.4$ & $0.32 \pm 0.07$ \\
\hline 6 & $0.053 \pm 0.002$ & $12 \pm 2$ & $8.1 \pm 0.1$ & $0.19 \pm 0.03^{c}$ \\
\hline 7 & $0.048 \pm 0.002$ & $13 \pm 2$ & $18 \pm 0.4$ & $0.47 \pm 0.04$ \\
\hline 8 & $0.0021 \pm 0.0001$ & $7.2 \pm 1$ & $28 \pm 0.3$ & $0.026^{d, e}$ \\
\hline 9 & $\sim 0.001^{b}$ & $1.9 \pm 0.2$ & $25 \pm 0.3$ & $0.0014^{d, e}$ \\
\hline 10 & $0.013 \pm 0.0002$ & $10 \pm 1$ & $19 \pm 0.3$ & $0.019^{d, e}$ \\
\hline 11 & $2.8 \pm 0.040$ & $110 \pm 8$ & $15 \pm 0.5$ & $51 \pm 20$ \\
\hline 12 & $N A(\leq 100)$ & $N A(\leq 100)$ & & $N A(\leq 354)$ \\
\hline 13 & $N A(\leq 77)$ & $\mathrm{NA}(\leq 77)$ & & $>300$ \\
\hline 14 & $N A(\leq 800)$ & $N A(\leq 800)$ & & $N A(\leq 582)$ \\
\hline 15 & $N A(\leq 800)$ & $N A(\leq 800)$ & & $N A(\leq 452)$ \\
\hline 16 & $N A(\leq 800)$ & $0.2-0.5^{\circ} \mathrm{C}(200-800)$ & & $>120$ \\
\hline 17 & $N A(\leq 99)$ & $N A(\leq 99)$ & & $N A(\leq 50)$ \\
\hline 18 & $N A(\leq 49)$ & $N A(\leq 49)$ & & $\mathrm{NA}(\leq 14)$ \\
\hline 19 & $\sim 280(\leq 286)$ & $0.2-0.5^{\circ} \mathrm{C}(18-72)$ & & $>150$ \\
\hline 20 & $\sim 71(\leq 50)$ & $N A(\leq 50)$ & & $>500$ \\
\hline 21 & $N A(\leq 200)$ & $\mathrm{NA}(\leq 25)$ & & $N A(\leq 286)$ \\
\hline
\end{tabular}

${ }^{a} K_{\mathrm{i}}$ (FP; Cy5-Nrf2 probe), EC $\mathrm{E}_{50}$ (TSA), and $K_{\mathrm{d}}$ (SPR) from steady state affinity analysis of SPR sensorgrams shown as mean \pm SEM; based on at least three individual measurements unless otherwise stated. NA: No activity. Maximum concentration tested is seen in parenthesis: Test concentrations of compounds 12, 13, 17, and 18 were limited by solubility-issues. For 16 and 19, $\mathrm{EC}_{50}$ could not be determined, but a $\Delta \mathrm{T}_{\mathrm{m}}$ of $0.2-0.5^{\circ} \mathrm{C}$ were found in the respective concentration ranges. Test concentrations of $\mathbf{1 9}$ were limited in FP by low stock concentration due to low amount available from vendor, and further limited in TSA by a sudden drop in fluorescence. Test concentrations of $\mathbf{2 0}$ and $\mathbf{2 1}$ were limited by increasing FP values at higher concentrations, and by a sudden drop in fluorescence (20) or auto-fluorescence (21) in TSA. ${ }^{b}$ The affinity was too high to calculate an exact $K_{\mathrm{i}}$, but $\mathrm{IC}_{50}$ value was $0.008 \mu \mathrm{M}$ ( 2 -fold lower than 8 ). ${ }^{c}$ Based on only two measurements. ${ }^{d}$ Based on only one measurement. ${ }^{e}$ One concentration injection or OneStep gradient injection sensorgrams were fitted to a kinetic 1:1 model. 
To check that the inhibition curves were not due to fluorescence artifacts (e.g. auto-fluorescence or chemical quenching of probe ${ }^{63}$ ) the total fluorescence intensity (FLINT) values were monitored and found stable for compounds 1-11 (Supporting Information Figure S2D) as expected for genuine inhibitors that do not disturb the fluorescence of the probe. Also, flat FP curves were seen when Keap1 was omitted from the assay (Supporting Information Figure S2E), which further validates that the concentration-dependent reduction in FP signal in the presence of Keap1 (Figure 2A) was due to inhibition of the Keap1-Nrf2 interaction.

Compounds $\mathbf{1 2 - 1 8}$ and $\mathbf{2 1}$ did not show any inhibition in the FP assay, while $\mathbf{1 9}$ and $\mathbf{2 0}$ only gave a weak signal (Figure 2B and Table 1). As these compounds were tested in higher concentrations than compounds 111, a DMSO concentration of $8 \%$ was used instead of $4 \%$ as for 1-11. Under these conditions, compounds $\mathbf{1 2}$, 13, 17, and 18 still had solubility issues, and thus their test concentrations had to be reduced to less than $800 \mu \mathrm{M}$ (Table 1). The maximum test concentration of 19 was limited to $286 \mu \mathrm{M}$ due to low availability of the compound, while compounds $\mathbf{2 0}$ and $\mathbf{2 1}$ showed increasing (artifactual) FP values at higher concentrations. Still, all compounds were tested at concentrations relevant for assessing their potential inhibitory activity (Table 1). Within these concentrations, the FLINT was flat (Supporting Information Figure S2F) and hence did not indicate any inner filter effects that would disturb the fluorescence-based (Cy5) FP measurements. Compound 20 was found unstable in assay buffer, as purity was reduced to $80 \%$ compared to $>98 \%$ of the original DMSO stock, with a main impurity corresponding in mass to a dehydration product.

Compounds $\mathbf{1 2}$ and 18-21 have all demonstrated activity in FP assays in literature with suggested affinity values of 7-15 $\mu \mathrm{M}$ (Figure 1A). ${ }^{35,40,46,62}$ However, in our hands only compounds 19 and 20 demonstrated some inhibition with $K_{\mathrm{i}}$ values around 280 and $71 \mu \mathrm{M}$, respectively, which is 10-24-fold higher than published $K_{\mathrm{i}}$ values of 15 and 3-7 $\mu \mathrm{M}$, respectively, ${ }^{35,62}$ while 12, 18, and 21 were completely inactive. To investigate this discrepancy, a series of follow-up experiments were conducted. First, we tested if an apparent inhibition of 12 and 18-21 in the FP assay requires the use of a fluorescein-based probe, and thus we repeated the assay using FAM-Nrf2. Again, compound $\mathbf{1 2}$ showed no inhibition, nor any sign of fluorescence interference as evidenced by the flat FLINT (Figure 2C-D). Compound $\mathbf{1 8}$ was not measurable in this assay, as both FP and FLINT dramati- 
cally increased with increasing concentrations. Compound 19 showed no activity when using the FAM-Nrf2 probe (Figure 2C), in contrast to the apparently weak inhibition seen in the Cy5-Nrf2-based FP assay (Figure 2B and Table 1). Compound 20 gave an apparent $I C_{50}$ value of $\sim 100 \mu \mathrm{M}\left(I C_{50}\right.$ and the corresponding $K_{\mathrm{i}}$ value were uncertain as inhibition did not go to baseline) and a stable FLINT throughout the concentration-response test (Figure 2C-D). Finally, $\mathbf{2 1}$ was inactive up to $50 \mu \mathrm{M}$ and could not be assessed with the FAM-probe at higher concentrations due to increasing FP and FLINT values (Figure 2C-D). Similar data were obtained for 12 and 1821 when the reducing agent tris(2-carboxyethyl)phosphine (TCEP) was excluded from the assay buffer (Supporting Information Figure S2G), and when mimicking the published assay conditions for $\mathbf{1 2},{ }^{40} \mathbf{1 8},{ }^{46}$ or $\mathbf{1 9 - 2 1}{ }^{35}$ with respect to e.g. exact assay buffer, DMSO concentrations, incubation times, and fluorescent probe (Supporting Information Figure S3).

Overall, 1-11 potently inhibited the Nrf2 peptide probe and Keap1 Kelch domain interaction, in accordance with literature. For 12-21, no convincing activity was seen in FP, which is in opposition to reported data.

\section{Stabilization activity in TSA.}

In the TSA, ligand binding is indicated by an increase in resistance to the temperature-dependent unfolding of the protein, quantified as an increase in the melting temperature $\left(T_{m}\right)$ relative to that obtained in the absence of ligand. ${ }^{66}$ TSA has previously been employed to characterize the inhibitors $\mathbf{3}$ and $\mathbf{1 9 - 2 1 .}{ }^{29,32,35,62}$ Here, we employed TSA to measure the $T_{m}$ values induced by the compounds at varying concentrations ( 9 points) to assess or confirm their ability to bind and stabilize the Keap1 Kelch domain (Figure 3 and Supporting Information Figure S4). 
A

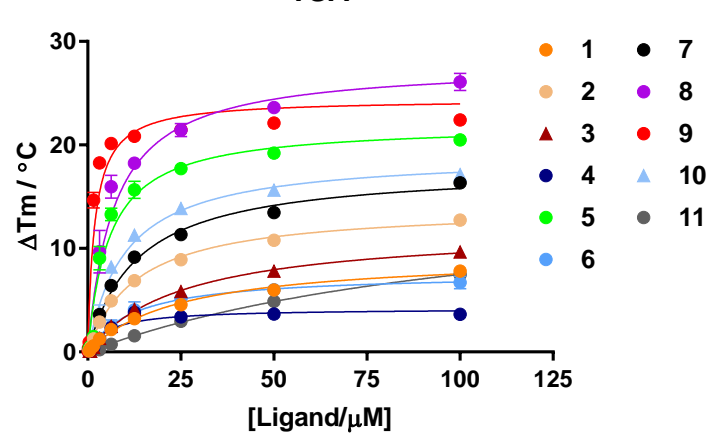

B

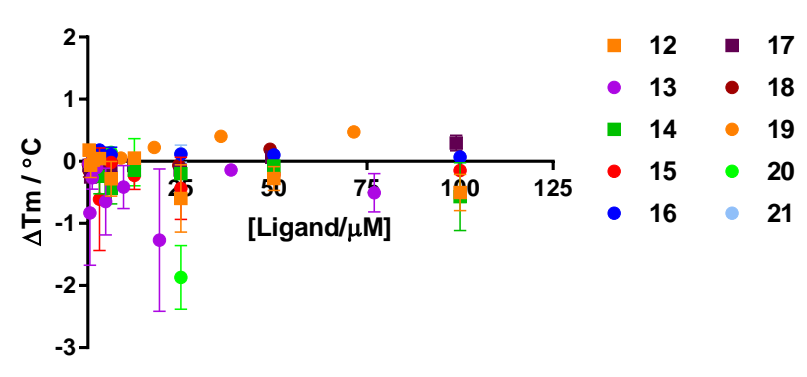

Figure 3. Concentration-dependent stabilization of the Keap1 Kelch domain by compounds 1-21 in the TSA. (A) Concentration- $\Delta T_{m}$-max curves for compounds 1-11. (B) Concentration- $\Delta T_{m}$-max curves for compounds 12-21. Average curves of $\geq 3$ individual measurements are here shown (as means \pm SEM).

Compounds 1-11 all show strong stabilization of the Kelch domain $\left(\Delta \mathrm{T}_{\mathrm{m}}\right.$-max of $\left.4-28{ }^{\circ} \mathrm{C}\right)$ in a concentration-dependent manner (Figure 3 and Table 1). Comparing the results of the TSA with those obtained from our FP assay, some correlation can be seen for the strongly binding compounds (low $K_{\mathrm{i}}$ values), e.g. compounds $\mathbf{5}$, 8, and 9, exhibiting correspondingly low $\mathrm{EC}_{50}$ and high $\Delta \mathrm{T}_{\mathrm{m}}$-max values in TSA (Table 1). However, 1, 3, and 11 have fairly high $\Delta \mathrm{T}_{\mathrm{m}}$-max values $\left(9-15^{\circ} \mathrm{C}\right)$ relative to their medium affinities ( $K_{\mathrm{i}}$ values of $\left.0.5-2.8 \mu \mathrm{M}\right)$. This lack of correlation between FP and TSA might be because ligand-induced thermal shifts are not only dependent on ligand affinity but potentially also specific contributions of enthalpy and entropy to binding and on the extent to which the ligand stabilizes the denatured state of the protein. ${ }^{66-68}$

Compound 3 has previously been reported with a $\Delta \mathrm{T}_{\mathrm{m}}$ - $\max$ of $1.3^{\circ} \mathrm{C}$, but was only titrated up to $38 \mu \mathrm{M}$, ${ }^{29 \text {, }}$ ${ }^{32}$ while we test it up to $100 \mu \mathrm{M}$. Still, our data suggests a $\Delta \mathrm{T}_{\mathrm{m}}$ of $7.5^{\circ} \mathrm{C}$ at $38 \mu \mathrm{M}$ (Figure $3 \mathrm{~A}$ ); a deviation that might be explained by differences in buffer and/or protein/dye concentrations. Unfortunately, the specific conditions used in the literature TSA were not reported.

Compounds 12-15, 17, 18, 20, and 21 did not show any significant concentration-dependent stabilization of the Kelch domain, while 16 and 19 showed only weak stabilization (Figure $\mathbf{3}$ and Supporting Information S4). Testing of $\mathbf{1 2}, \mathbf{1 3}, \mathbf{1 7}$, and 18 was limited by solubility issues as also found in the FP assay, but no significant 
thermal shifts were detected up to $100,77,99$, and $49 \mu \mathrm{M}$, respectively (Table 1). Compounds 19-21 showed sudden changes in fluorescence, i.e. the fluorescence promptly and significantly dropped at concentrations > $200 \mu \mathrm{M}$ for compound 19 and at $\geq 100 \mu \mathrm{M}$ for compound 20, indicating fluorescence quenching or protein degradation, while the fluorescence increased for $\mathbf{2 1}$, suggesting auto-fluorescence (Supporting Information Figure S4). Compounds 19-21 have demonstrated thermal shifts in literature, but all showed negative $\Delta \mathrm{T}_{\mathrm{m}}$ values $\left(-2,-5\right.$, and $-1{ }^{\circ} \mathrm{C}$, respectively).$^{35}$

To summarize, the TSA showed compounds 1-11 to potently stabilize Keap1 Kelch domain, while no significant or comparable activity was seen for 12-21; this aligns with and confirms the FP results.

\section{Binding activity in SPR assay.}

To characterize direct binding between the Keap1 Kelch domain and compounds 1-21, SPR was applied. The Kelch domain was immobilized covalently to a biosensor chip, and the compounds were injected in two-fold dilution series. Binding curves for compounds 1-7 and $\mathbf{1 1}$ showed concentration dependent binding responses, approaching or reaching saturation for the highest concentrations injected (Figure 4). Dissociation constants $\left(K_{d}\right)$ for these compounds could be derived by steady state affinity analysis, where the SPR responses at equilibrium $\left(R_{\text {eq }}\right)$, observed at the end of compound injection, were plotted against the injected concentrations and fitted to a Langmuir (1:1) binding isotherm model (Figure 4 and Table 1). Also, binding to the Kelch domain was confirmed for compounds 8-10, which showed a very slow dissociation from immobilized protein, indicative of very strong binding. Regeneration conditions to abrogate compound binding to protein between analyte injections (so the response would return to baseline between analyte injections) could not be established for 8-10. Thus, affinity analysis from dose-response experiments were not achievable for these. Instead, compounds 810 were injected either by single concentration injection or by a gradient OneStep injection (Figure 5), ${ }^{69,70}$ and the SPR curves were globally fitted to a simple 1:1 kinetic interaction model from where dissociation constants $\left(K_{\mathrm{d}}\right)$ in the low nanomolar range were derived (Figure 5 and Table 1). 

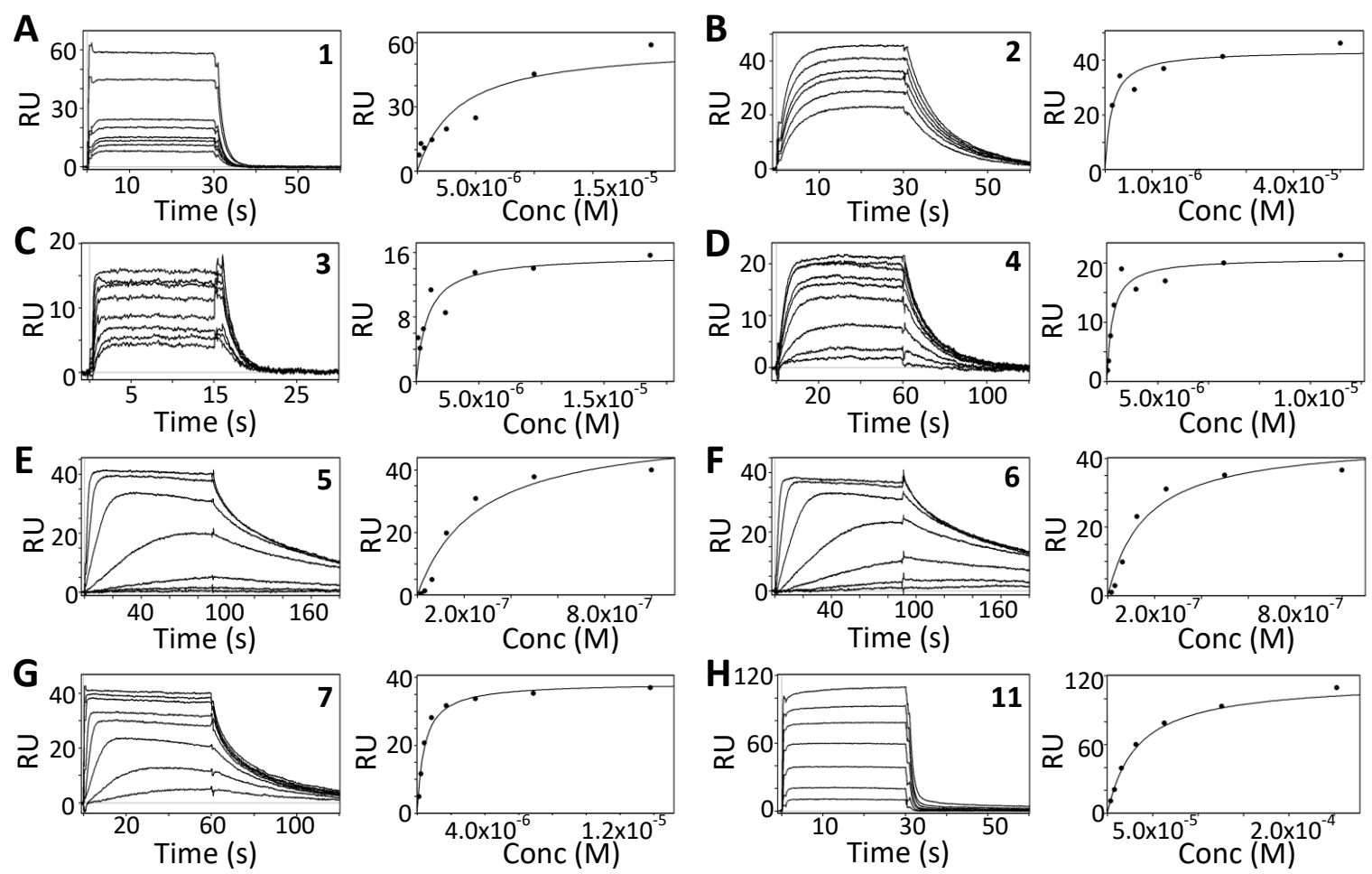

Figure 4. SPR sensorgrams of compounds 1-7 and $\mathbf{1 1}$ interacting with immobilized Keap1 Kelch domain. (A-H) Compounds 1-7 and 11 were injected in two-fold serial dilutions (7-8 concentrations) over immobilized Kelch domain (left panels). Sensorgrams are blank injection and reference surface subtracted. Right panels display plots of equilibrium binding responses at the end of the analyte injections from sensorgrams in left panels against analyte concentration. Steady state equilibrium dissociation constants $\left(K_{d}\right)$ from curves fitted to a 1:1 model are presented in Table 1.
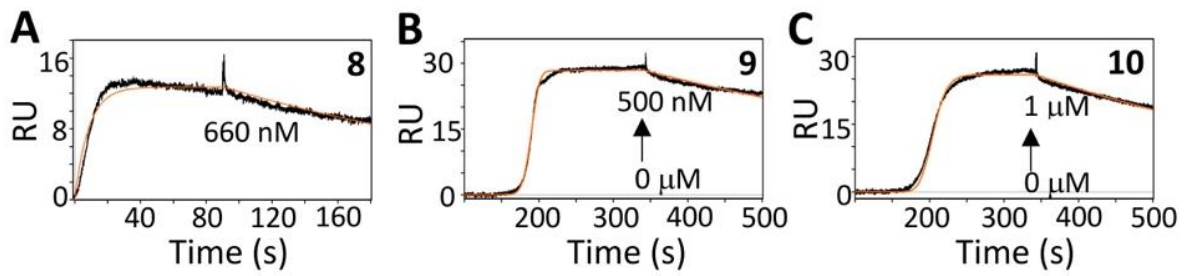

Figure 5. SPR sensorgrams of compounds 8-10 interacting with immobilized Keap1 Kelch domain. (A) Compound 8 was injected in one concentration $(660 \mathrm{nM})$ over immobilized Kelch domain. Kinetic fit of the sensorgram to a 1:1 Langmuir model was performed (red line), and the rate constants $k_{a}$ and $k_{d}$ were calculated to $1.73 \times 10^{5} \mathrm{M}^{-1} \mathrm{~s}^{-1}$ and $4.43 \times 10^{-3} \mathrm{~s}^{-1}$, respectively. (B) Compound 9 was injected by OneStep gradient injection up 
to $500 \mathrm{nM}$ over immobilized Kelch domain. Kinetic fit of the sensorgram to a 1:1 Langmuir model was performed (red line) and the rate constants $k_{a}$ and $k_{d}$ were calculated to $1.1 \times 10^{6} \mathrm{M}^{-1} \mathrm{~s}^{-1}$ and $1.58 \times 10^{-3} \mathrm{~s}^{-1}$, respectively. (C) Compound $\mathbf{1 0}$ was injected by OneStep gradient injection up to $1 \mu \mathrm{M}$ over immobilized Kelch domain. Kinetic fit of the sensorgram to a 1:1 Langmuir model was performed (red line), and the rate constants $k_{a}$ and $k_{d}$ were found to be $1.16 \times 10^{5} \mathrm{M}^{-1} \mathrm{~s}^{-1}$ and $2.26 \times 10^{-3} \mathrm{~s}^{-1}$, respectively. Sensorgrams are blank injection and reference surface subtracted. Dissociation constants $\left(K_{\mathrm{d}}\right)$ from kinetic fits of sensorgrams are presented in Table 1.

The SPR sensorgrams of compounds 12, 14, 15, 17, and 18 revealed no binding to the Kelch domain, while some response was seen for 13, 16, and 19-21 at the tested concentrations (Supporting Information Figure S5A-I and Table 1). However, 13 and $\mathbf{1 6}$ bound only very weakly to the domain; further, the shape of the sensorgrams of 19-21 indicated non-specific binding, by either showing a disproportional increase in response level with concentration, a response not reaching steady-state phase, or lack of binding saturation.

Compounds 3-6 and 13-15 have previously been described to show binding to Keap1 by SPR (Figure 1A). ${ }^{29,31,34}$ For compound 3, the determined $K_{d}$ of $2.4 \mu \mathrm{M}$ (Table 1 ) was in similar range of the reported $K_{d}$ values of $1 \mu \mathrm{M}^{29}$ and $0.8 \mu \mathrm{M}^{31}$. The SPR determined affinity $\left(K_{\mathrm{d}}\right)$ of 4 was similar to the $K_{\mathrm{i}}$ value determined by FP (Table 1), although lower than the $K_{d}$ reported in literature. ${ }^{34}$ Compounds 5 and 6 showed $K_{d}$ values of 20$44 \mathrm{nM}$ by SPR in earlier reports (Figure $1 \mathrm{~A}$ ), ${ }^{31,34}$ which are similar to our FP $K_{\mathrm{i}}$ values, but several fold lower than our SPR $K_{d}$ values (Table 1); still, 5 and $\mathbf{6}$ are here confirmed by SPR to be potent binders. Compound 13 was previously found to bind to the Kelch domain with a $K_{\mathrm{d}}$ of $22.8 \mu \mathrm{M}$ based on injections of three concentrations in an SPR experiment not reaching binding saturation. ${ }^{41}$ In our hands, 13 only showed weak binding responses when tested up to $307 \mu \mathrm{M}$. The reported SPR data for 14 showed very weak responses ( $\leq 5 \mathrm{RU})$ not approaching binding saturation level when tested up to $100 \mu \mathrm{M}$; thus, $K_{d}$ in this previous study was estimated to be higher than $100 \mu \mathrm{M} .{ }^{42}$ Here, no binding was observed for $\mathbf{1 4}$ to the Kelch domain, even when tested at concentrations up to $582 \mu \mathrm{M}$. Compound 15 was reported to show a dose dependent SPR sensorgram when 
tested up to $100 \mu \mathrm{M} .{ }^{43}$ However, the SPR sensorgram published, shows only very weak SPR responses for 50 and $100 \mu \mathrm{M}$ injections ( $\leq 5 \mathrm{RU}) .{ }^{43}$ We were not able to confirm any binding in our study when testing 15 up to a concentration of $452 \mu \mathrm{M}$.

Compounds 7-11 have not previously been investigated by SPR. Compound $\mathbf{7}$ gave a $K_{\mathrm{d}}$ of $0.47 \mu \mathrm{M}$, thereby confirming the nanomolar affinity seen in FP (Figure $1 \mathbf{A}^{36}$ and Table $\mathbf{1}$ ). Compounds 8-10 showed the highest affinities among the tested compounds in our FP assay ( $K_{\mathrm{i}}$ values of $1-13 \mathrm{nM}$ ). This was confirmed by the single concentration SPR experiments ( $K_{\mathrm{d}}$ values of $1.4-26 \mathrm{nM}$; Table 1$)$ and is in line with the reported affinity values of 1-200 nM based on FP or ITC (Figure 1A). ${ }^{27,38,39}$ For 11, we experienced an 18-fold discrepancy in the FP $K_{\mathrm{i}}$ value and SPR $K_{\mathrm{d}}$ value (Table 1). This is likely explained by 11 binding 2:1 with the Kelch domain, as observed by native LC-MS and X-ray crystallography, ${ }^{33}$ which would lead to a lower apparent affinity in SPR measuring direct binding, but not in FP if the initial binding event leads to displacement of the peptide probe. Noticeably, in SPR we see a 2-fold higher $R_{\max }$ for $\mathbf{1 1}$ compared to other active compounds (Figure 4), which supports the suggested 2:1 stoichiometry of $\mathbf{1 1}$ binding to the Kelch domain.

In conclusion, compounds 1-11 showed direct binding to the Keap1 Kelch domain by SPR, thereby confirming our own FP and TSA results as well as the literature reports. On the other hand, SPR did not reveal any clear interaction with the Kelch domain for $\mathbf{1 2 - 2 1}$, as also seen by FP and TSA.

\section{Cell activity in NQO1 induction assay.}

To evaluate the downstream cellular activities of the compounds, we tested their ability to induce NQO1 enzyme activity at varying concentrations $(1,5$, and $10 \mu \mathrm{M})$ in Hepa1c1c7 murine hepatoma cells using sulforaphane (SFN) as a positive control. ${ }^{71}$ The peptide controls $\mathbf{1}$ and $\mathbf{2}$ were inactive, likely because of the inherently limited physicochemical properties of peptides for permeating biological membranes, which also correlates with the low cellular effect seen for other Neh2-derived peptides. ${ }^{25}$ The small-molecules confirmed to be genuine Keap1-Nrf2 PPI inhibitors (3-11) in our binding assays modestly to strongly induced NQO1 specific enzyme activity in a dose-responsive manner, with exception of compounds $\mathbf{6}$ and $\mathbf{1 1}$ (Figure 6A). Compound 6 
did not show any statistically significant NQO1 induction, despite its strong binding to the Kelch domain (e.g. 3 and 4 exhibit weaker affinities in FP and SPR, but did induce NQO1 activity). This could be due to the lower cLogP and higher polar surface area featured by 6 relative to compounds 3 and $4,{ }^{10}$ which might decrease its passive diffusion across the cell membrane. Compound 5 also has a high polar surface area relative to $\mathbf{4}$, but its high affinity towards the Kelch domain is likely to compensate for this, hence resulting in a cell-active compound. The functional Nrf2 activation of $\mathbf{6}$ has not previously been reported, while 3-5 have shown activity in ARE-inducing cell assays. ${ }^{22,} 29,33$ For compound 11, the lack of cell activity may be explained by its relatively weak binding activity as observed in FP, TSA, and SPR. In literature, $\mathbf{1 1}$ showed no activity in an ARE-driven luciferase reporter cell-based assay. ${ }^{33}$ Compounds 7-10 were among the strongest binding ligands in our FP, TSA, and SPR assays and were also potent NQO1 inducers, comparable to or exceeding SFN. These results are in line with literature, where 7-10 have all demonstrated activity in NQO1-based or ARE-driven cell assays. ${ }^{27,36,38,39}$ 


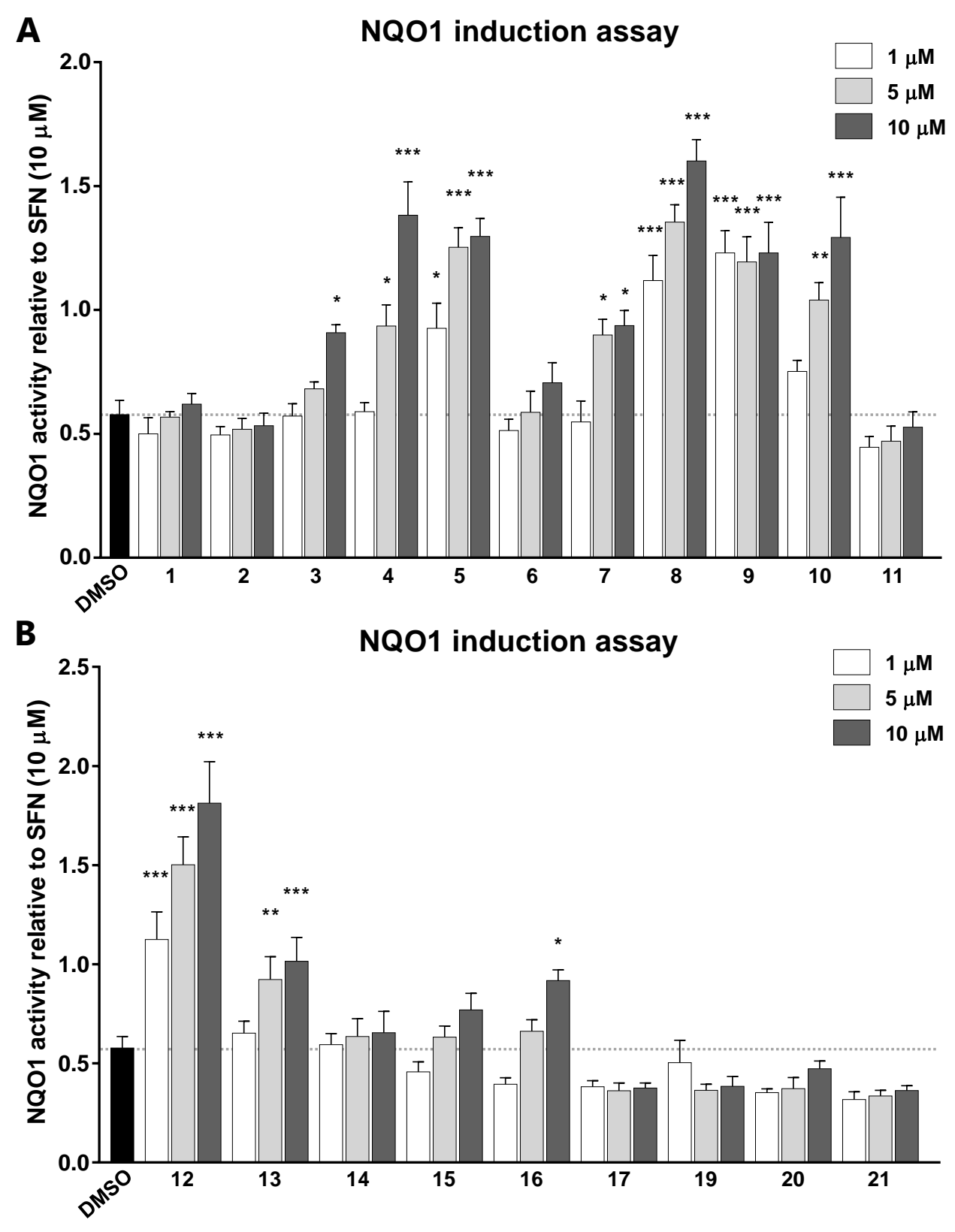

Figure 6. NQO1 fold induction at 1, 5, and $10 \mu \mathrm{M}$ of compounds $\mathbf{1 - 1 1}(\mathrm{A})$ and $\mathbf{1 2 - 1 7 , ~ 1 9 - 2 1 ~ ( B ) ~ r e l a t i v e ~ t o ~ t h e ~}$ positive control SFN $(10 \mu \mathrm{M})$ shown as mean \pm SEM; based on at least four individual measurements. Statistical significance of differences relative to DMSO is indicated as follows: ${ }^{*} p<0.05 ;{ }^{* *} p<0.01 ;{ }^{* *} p<0.001$; Student's two-tailed, unpaired $t$-test.

Compound 12 potently and concentration-dependently induced NQO1 activity (Figure 6B), which is consistent with the high cellular potency demonstrated previously in an analogous NQO1 induction assay (a 4-fold induction at $10 \mu \mathrm{M}$ was reported)..$^{40}$ However, this result is inconsistent with our binding assays, where we see 
no binding to the Keap1 Kelch domain or inhibition of its interaction with Nrf2 for compound 12. A growing body of literature has revealed a multitude of regulatory switches through which the activity of Nrf2 can be modulated independently of Keap1. ${ }^{14,72}$ We recognize that compound $\mathbf{1 2}$ has been shown to be able to disrupt the low-affinity DLG-Keap1 interaction to form an open state complex in a FRET-based assay in live cells; ${ }^{40}$ however, this does not necessitate direct binding to the Keap1 Kelch domain, and the existence of an open state conformation of the Keap1-Nrf2 complex has also been associated with multiple modes of regulation. ${ }^{9}$ Thus, it remains a possibility that the confirmed potent NQO1 induction exhibited by $\mathbf{1 2}$ is not dependent on binding to the Keap1 Kelch domain.

Compound 13 induced NQO1 activity to a similar level as SFN, which is consistent with literature results (concentration to give a two-fold increase in response $(C D)=1.3 \mu \mathrm{M}) .{ }^{41}$ As for 12 , this contradicts our binding assay results, where no binding to the Kelch domain was observed in relevant concentrations; thus, again Kelch binding-independent Nrf2 regulation must explain the cellular activity as also discussed below.

Compounds 14 and 15 did not show any statistically significant increase in NQO1 activity, while 16 only exhibited weak induction at $10 \mu \mathrm{M}$; this correlates with the inactivity or only very weak activity seen in our binding assays. The cellular activity has not previously been demonstrated for 14 , but 15 and 16 have both shown modest activities in luciferase-based cell assays $\left(C D=1.36 \mu \mathrm{M}\right.$ and $2.5 \mu \mathrm{M}$, respectively). ${ }^{43,44}$ We note that different assay conditions, including different cell lines, were used in the literature for assessing the cellular activities of $\mathbf{1 5}$ and $\mathbf{1 6}$ compared to what was used here.

Compound 17 was inactive in our binding assays and correspondingly showed no increase in NQO1 activity. However, this contradicts the literature, since the compound has been reported to potently induce NQO1 in Hepa1c1c7 cells $(C D=0.07 \mu \mathrm{M}) .{ }^{45}$ We cannot readily account for this discrepancy, and unfortunately only scarce information has been reported about the details of the previously used assay, preventing crossexamination for potential differences and identification of an underlying cause. We note that a positive control (e.g. SFN) appears not to have been employed in the literature assay. ${ }^{45}$ We also note that compound $\mathbf{1 7}$ had very limited aqueous solubility and therefore had to be assayed with 1.0\% DMSO. 
Compound 18 was tested up to $10 \mu \mathrm{M}$ without observing any NQO1 induction relative to DMSO (data not shown). However, due to the low solubility of $\mathbf{1 8}$, a relatively high DMSO concentration (1.4\%) was applied to reach $10 \mu \mathrm{M}$ of 18 in the assay, but under these conditions SFN was not active. Also, when testing a lower concentration of $18(0.9 \mu \mathrm{M})$ at a DMSO concentration of $0.13 \%$, where SFN was active, no activity was observed (data not shown). Compound $\mathbf{1 8}$ has previously been shown to activate Nrf2 in an ARE-driven luciferase-based cell assay with a 10 -fold induction at $200 \mu \mathrm{M}$ and without cytotoxic activity. ${ }^{46}$ We speculate however, whether the literature cellular activity could in fact be artifactual, since structurally, compound $\mathbf{1 8}$ bears much resemblance to known classes of urea- and hydrazine-based luciferase enzyme inhibitors, which are able to confound readings from gene reporter assays. ${ }^{73}$

Compounds 19-21 did not show any significant NQO1 induction, correlating with the unobserved or unconvincing activities seen in our binding assays. Cellular activities of $\mathbf{1 9}$ and $\mathbf{2 1}$ have not hitherto been demonstrated, while compound $\mathbf{2 0}$ has previously been reported to elevate mRNA levels of $\mathrm{NQO} 1{ }^{35}$ however, the induction was weak and it was not shown whether it was statistically significant relative to the blank control.

In conclusion, our NQO1 induction assay confirms the cellular potencies of the compounds also established to bind Keap1 Kelch domain, i.e. compounds $\mathbf{3} \mathbf{- 5}$ and $\mathbf{7 - 1 0}$, while the weak or non-binding compounds 14-21 correspondingly showed no or only weak increase in NQO1 activity. Outliers from this correlation include the peptides 1 and $\mathbf{2}$ and compounds $\mathbf{6}$ and 11, where improper physicochemical properties might be a possible reason for their cellular inactivity. Other aberrations include compounds $\mathbf{1 2}$ and $\mathbf{1 3}$ that show modest to strong NQO1 induction despite not showing any activity in our binding assays, wherefore we suggest these cellular effects are due to mechanisms independent from binding to the Keap1 Kelch domain.

\section{Counter assays for covalent reactivity, redox cycling, and aggregations.}

We next tested the 21 compounds for common liabilities, which can cause false-positive signals in biochemical assays. ${ }^{53}$ First, we evaluated the compounds for covalent reactivity since several of these contain electrophilic 
functional groups, which could potentially react with protein amino acid residues, especially cysteines. In separate experiments, we incubated the compounds at 2-800 $\mu \mathrm{M}$ under our binding assay conditions with $2 \mu \mathrm{M}$ Keap1 Kelch domain and with $1 \mathrm{mM}$ glutathione (GSH) as a cysteine residue surrogate, respectively. ${ }^{74,75}$ Potential covalent binding was assessed by LC-MS or UPLC-MS. The known covalent modifier, SFN, was employed as a positive control in both experiments, which as expected showed clear adduct formation with both the Keap1 Kelch domain at $\geq 20 \mu \mathrm{M}$ and with $\mathrm{GSH}$ at $500 \mu \mathrm{M}$ (Supporting Information Figure S6 and S7A). However, SFN was not active in the FP assay (Supporting Information Figure S8B), demonstrating that this assay is generally not sensitive to covalent modifiers. Interestingly, incubation of the Keap1 Kelch domain with compounds 11, 13,19 , and 20 all resulted in significant changes of the mass spectrum of the protein (Supporting Information Figure S6A). For 11, 13, and 20 distinct mass adducts were formed at 800,200 and $20 \mu \mathrm{M}$, respectively, and these could be attributed to the nucleophilic displacement of labile thiolate moieties in their structures by protein cysteines (Figure 7A). For compound 19, strong perturbation of the mass spectrum was observed at $800 \mu \mathrm{M}$ with the apparent disappearance of mass signals, indicating protein denaturation or degradation. This phenomenon was also observed at $200 \mu \mathrm{M}$ of $\mathbf{1 3}$ (Supporting Information Figure S6A) and 20 (not shown). For compound 20, covalent reactivity was further observed in the incubation experiment with GSH with detection of a clear adduct formation (Supporting Information Figure S7B), while this was not seen for 11, 13, and 19. This discrepancy might be explained by the known effect of the protein microenvironment, including solvent exposure and local $\mathrm{pH}$, on the reactivity of cysteine thiols. ${ }^{76,77}$ 
A
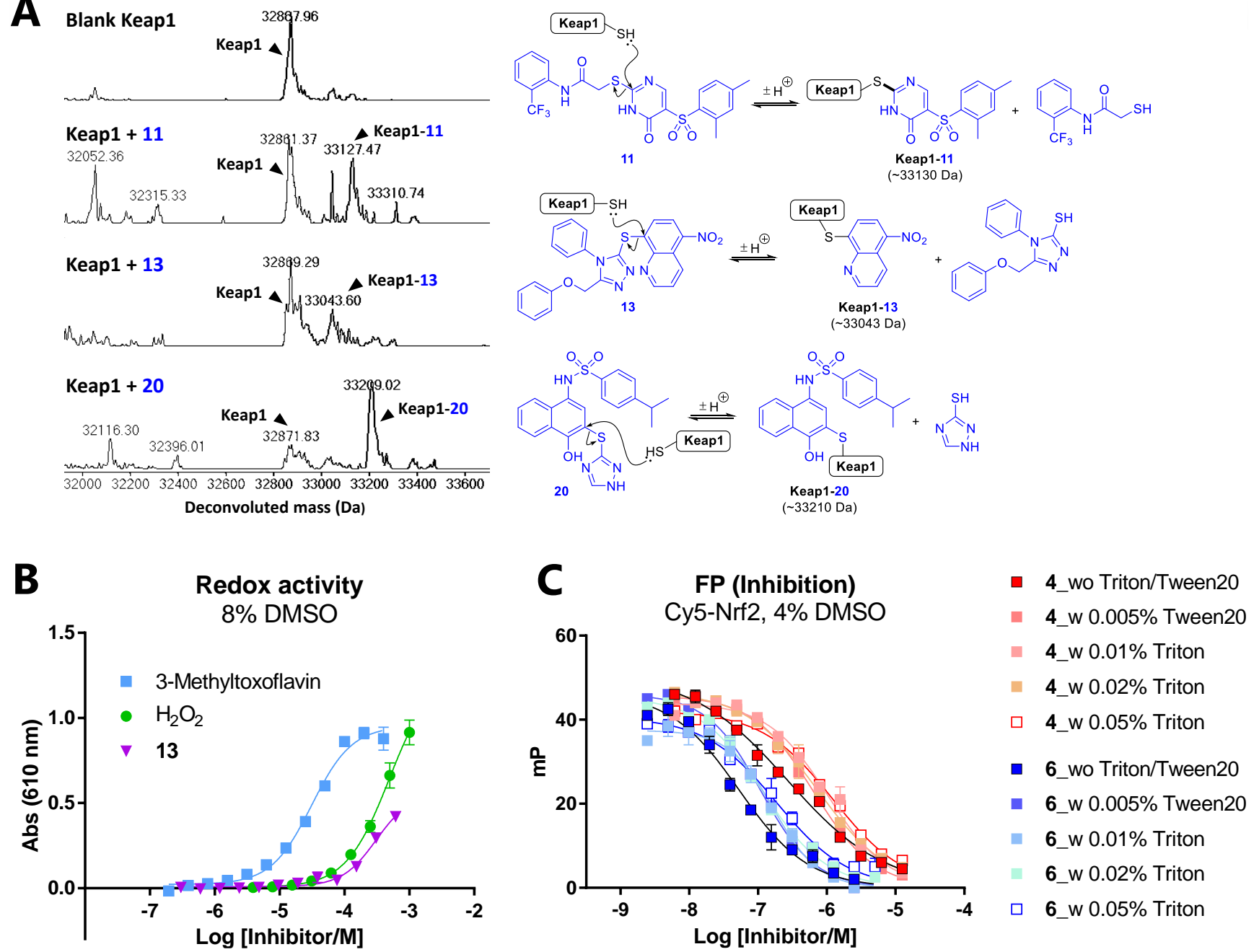

Figure 7. (A) Covalent reactivity of compounds 11, 13, and 20 towards the Keap1 Kelch domain as assessed by LC-MS. All compounds were incubated with $2 \mu \mathrm{M}$ protein at various concentrations/stoichiometries (1:1, 10:1, 100:1, and 400:1). Shown are deconvoluted mass spectra for the Kelch domain incubated with 11 at 800 uM (no adduct formation seen at lower concentrations), with 13 at $200 \mathrm{uM}$, and with 20 at 20 uM (no adduct formation seen at lower concentrations, protein signal disappearance seen at higher concentrations). The raw charge envelope spectra can be found in the Supporting Information Figure S6A. The proposed reactions occurring are shown to the right. (B) Redox activity of 13 as measured by $\mathrm{H}_{2} \mathrm{O}_{2}$ generation in presence of $1 \mathrm{mM}$ TCEP and in comparison with known redox-active 3-methyltoxoflavin and externally added $\mathrm{H}_{2} \mathrm{O}_{2}$. Representative curves of two individual measurements are shown as means of duplicates \pm SEM. (C) FP concentrationresponse curves for $\mathbf{4}$ and $\mathbf{6}$ without (wo) detergent or with (w) various concentrations of Tween20/Triton X100. Representative curves of two individual measurements (wo Triton/Tween20, w $0.005 \%$ Tween 20 , and w 
$0.01 \%$ Triton X-100) or one measurement (w 0.02 and $0.05 \% \%$ Triton X-100) are shown as means of duplicates \pm SEM.

Redox cycling compounds (RCCs) generate $\mathrm{H}_{2} \mathrm{O}_{2}$ in the presence of strong reducing agents like TCEP and DTT, which can affect proteins and lead to false readouts..$^{53,78-81}$ As we have TCEP in our standard assay buffer, we tested if 1-21 produced $\mathrm{H}_{2} \mathrm{O}_{2}$ using an assay based on oxidation of phenol red by $\mathrm{H}_{2} \mathrm{O}_{2}$ catalyzed by horseradish peroxidase. ${ }^{81}$ Interestingly, compound $\mathbf{1 3}$ gave a clear TCEP-dependent response starting at $77 \mu \mathrm{M}$, with absorbance values about 2-3-fold lower than corresponding concentrations of pure $\mathrm{H}_{2} \mathrm{O}_{2}$ added as a positive control. Compared to the control compound 3-methyltoxoflavin, 13 was $\sim 20$-fold less potent (Figure 7B). The remaining compounds did not give any signal (Supporting Information Figure S8A). 3-Methyltoxoflavin and $\mathrm{H}_{2} \mathrm{O}_{2}$ showed no activity in the FP assay (Supporting Information Figure S8B); thus this assay is not sensitive to RCCs.

Aggregate-forming compounds are typically much more potent without presence of detergent and can thereby be identified by performing the biochemical assay with and without $0.01 \%$ Triton X-100. ${ }^{82,83}$ Here, we observed no difference for 1-3, 5, 7-11, and 19-20 in the FP assay with $0.01 \%$ or without Triton X-100 (Supporting Information Figure S8C) or when compared to our usual assay conditions using $0.005 \%$ Tween20 (Fig. 2). Compound 12-18 and $\mathbf{2 1}$ were inactive without Triton X-100 and were therefore not tested further. Benzyl benzoate and clotrimazole were inactive in our FP assay both with and without detergent (Supporting Information Figure S8B), indicating that our FP assay is robust to typical promiscuous aggregators. ${ }^{84}$ Compound 4 and 6, however, were both 2-4-fold more potent without detergent than with $0.01 / 0.02 / 0.05 \%$ Triton X-100 and $0.005 \%$ Tween20 gave similar results) (Figure 7C).

\section{DISCUSSION AND CONCLUSIONS}

Nrf2 activation through disruption of the Keap1-Nrf2 PPI has been recognized as a promising strategy to combat oxidative stress in peripheral as well as CNS diseases, such as stroke and neurodegenerative disorders. Alt- 
hough our artillery of direct small-molecule Keap1-Nrf2 PPI inhibitors has grown significantly throughout the years, many of these compounds feature physicochemical properties inappropriate for passing the BBB. However, further optimization might address this problem. Other reported inhibitors contain potentially problematic substructural motifs or have only been scarcely characterized. In order to rid the literature of problematic compounds, investigate the reproducibility of their synthesis and reported activities, and allow selection of the most promising starting points for lead optimization we have here performed an extensive comparative assessment study of all reported non-covalent small-molecule Keap1-Nrf2 PPI inhibitor classes that we are aware of (Figure 1A).

Initially, compounds 3-12, 14, 16, and 17 were synthesized, generally following reported procedures. Adjustments and attention to procedural details were necessary to obtain $\mathbf{3 , 4 - 8}$, and 10 in reasonable yields, and new procedures were developed for $\mathbf{1 1}$ and $\mathbf{1 7 .}$

To evaluate the binding efficiency and cellular potency of the obtained compounds 3-21, we tested them together with two positive peptide controls $\mathbf{1}$ and $\mathbf{2}$ in our triad of orthogonal binding assays, FP, TSA, and SPR, and further in a cellular NQO1 induction assay. To our surprise, we were not able to demonstrate convincing binding activity of half of the compounds, i.e. 12-21. By careful use of control experiments, we revealed compounds 18, 19, and 21 to exert fluorescence interfering activities, which for 19 and $\mathbf{2 1}$ correlates with the inclusion of PAINS moieties in their structure. ${ }^{10,52}$ Although we did detect weak inhibition for compound 19 and 20 in our FP assay, the binding efficiency was unsteady across different assay conditions. Importantly, we observed stability issues of $\mathbf{2 0}$ during QC by LC-MS subsequent to assaying; furthermore, the compound formed a covalent adduct with GSH and, as $\mathbf{1 9}$, severely distorted the mass spectrum of Keap1 indicating various forms of reactivity or deteriorations of the protein. We recognize that SAR has been conducted around the scaffold of 20 to produce modestly potent compounds. ${ }^{62}$ However, our observations, and the fact that degradation under assay conditions, protein-adduct formations, and even protein denaturation have been reported in literature for similar 4-hydroxyarylsulfonamides, ${ }^{75}$ raise serious concerns for the utility of this particular chemotype in drug discovery. 
For compounds 16 and 17, binding to Keap1 Kelch domain has only been hypothesized, ${ }^{44,45}$ and we here provide evidence that they do not bind the domain or inhibit the Keap1-Nrf2 PPI at relevant concentrations. However strikingly, we were able to reproduce the modest cellular NQO1 induction potency of compound 16, and our results thus suggest that $\mathbf{1 6}$ is able to induce NQO1 through a pathway independent of binding to the Keap1 Kelch domain.

For compound 12, there is a discrepancy between the reported low micromolar inhibition in $\mathrm{FP}\left(\mathrm{IC}_{50}=\right.$ $7.1 \mu \mathrm{M})^{40}$ and the inactivity seen in our FP assay. Even when replicating the exact assay conditions detailed in literature to exclude any confounding effects (e.g. different fluorescent probes, buffers, DMSO concentrations, or incubation time) we did not observe any inhibition. Furthermore, our TSA and SPR assay confirm this result with no observed binding. Of note, we have carefully checked the purity and compound identity of the DMSOstock by NMR and LC-MS and quantified our stocks by qHNMR. We therefore question that this compound can inhibit the Keap1-Nrf2 PPI via binding to the Keap1 Kelch domain, and perhaps pathways independent of Keap1 or Keap1 Kelch binding are affected, giving rise to the cellular induction of NQO1 observed in literature ${ }^{40}$ and by us.

Compounds 13-15 have previously been biophysically characterized by SPR to bind the Keap1 Kelch domain, ${ }^{41-43}$ but we did not observe any activity for these in any of our binding assays. However, it is worth noticing that 14 and $\mathbf{1 5}$ have only been reported with weak millimolar binding affinity and very low response units in the SPR sensograms. ${ }^{42,}{ }^{43}$ We realize that X-ray structures of $\mathbf{1 4}$ in complex with the Kelch domain have been reported; however, multiple binding modes had been identified, and these appeared not to represent solutionphase binding based on molecular dynamics simulation. ${ }^{42}$ Furthermore, the high sensitivity of X-ray crystallography can allow even weak ligands (e.g. fragments and salts) to bind. For compound 13, we highlight that the literature SPR affinity appears only to have been calculated based on sensorgrams from three concentrations, where binding saturation seems not to be have been reached. ${ }^{41}$ As for $\mathbf{1 2 , 1 3}$ was active in the NQO1 cell assay despite not showing any activity in the binding assays (FP, TSA, and SPR). Perhaps, this cellular effect is related to its apparent capability of producing $\mathrm{H}_{2} \mathrm{O}_{2}$, as observed in our redox counter test. Although, the concentra- 
tions used in the NQO1 cell assay $(1-10 \mu \mathrm{M})$ are much lower than the concentrations where we see redoxactivity $(\geq 77 \mu \mathrm{M})$, the cells could be sensitive to lower levels of $\mathrm{H}_{2} \mathrm{O}_{2}$, and incubation times are also longer in the cells. Also, by LC-MS we observed that $\mathbf{1 3}$ reacted with the Keap1 Kelch domain, presumably at the cysteine side chains. Such reactivity was also suggested in the patent application of $\mathbf{1 3}$ based on SAR studies and a cellular experiment where GSH pre-incubation lead to reduced potency of $13,{ }^{41}$ and correlates with the thiolreactivity observed for structurally similar compounds. ${ }^{75}$ Such mechanism of actions would reconcile our binding assay data with the results of the cellular assay, since electrophilic modulators of Keap1 canonically react with cysteine residues in the IVR and BTB domains of Keap $1,{ }^{14}$ which would not be detected in our Kelch domain-based binding assays.

Our observation that compounds able to induce NQO1 in the cell do not necessarily show binding to the Keap1 Kelch domain (as seen for 12, 13, and 16) highlights the crucial deficiency of characterizing compounds solely based on cellular activities. The NQO1 induction assay-like many other cellular assays-is prone to give positive readouts that are not a consequence of engagement with the target of interest; e.g. progesterone is known to upregulate NQO1 without activating the Nrf2 pathway. ${ }^{85}$ To confirm on-target activity, testing in both multiple orthogonal binding assays as well as several cell/in vivo assays are needed; e.g. by monitoring the gene or protein expression of other relevant downstream targets of the Nrf2 pathway, by measuring the nuclear translocation of Nrf2, or by directly imaging Keap1-Nrf2 interaction in cells. ${ }^{26}$

Compounds 3-11 are all well-characterized in the literature, and here we confirm that they are genuine reversible binders of the Keap1 Kelch domain that can inhibit the Keap1-Nrf2 PPI. Compound 11 did react covalently to the Keap1 Kelch domain, however, this was only seen at high compound concentrations ( $800 \mu \mathrm{M})$, and also SPR data indicated reversible binding. Together with our robust FP and TSA data, as well as X-ray and native LC-MS data from literature, ${ }^{33}$ a reversible binding mechanism seems to be prevailing for $\mathbf{1 1}$. Hence, both compounds $\mathbf{3}$ and $\mathbf{1 1}$ could constitute reliable positive controls, featuring modest micromolar affinities and good aqueous solubilities-properties suitable for setting up assays for screening low-potent compounds such as fragments. 
For compounds 4 and 6, a 2-4-fold higher $\mathrm{IC}_{50}$ value was seen in FP when detergent was present compared to when absent. This relatively small shift in potency could be related to the aqueous kinetic solubility, which for 4 and $\mathbf{6}$ was recently shown to be much lower than less hydrophobic analogues in the series, e.g. compound $5 .{ }^{86}$ Overall, 4 and 6 have been shown by X-ray crystallography to bind in the Keap1 Kelch binding pocket, and they give saturable and dose-dependent responses in SPR; thus we consider 4 and 6 to be genuine Keap1 binders. However, to minimize aggregation formations and increase precision when measuring, it is advisable to include detergent in the assay, also for these compounds.

Compounds $\mathbf{5}$ and 7-10 are all high-affinity and cell active compounds without any apparent chemical liabilities, such as covalent binding, redox activity, or aggregation properties. More extensive profiling of compounds $\mathbf{5}$ and 7-10 might be needed in order to further prioritize in between these, e.g. by assessing their selectivity towards the Keap1 Kelch domain, which has thus far only been demonstrated for compounds $\mathbf{7}$ and 9. ${ }^{27,}{ }^{36}$ Off-target activities cannot be excluded for compounds $\mathbf{5}, \mathbf{8}$, and $\mathbf{1 0}$, based on our or literature in vitro/cellular data. However, based on their physicochemical properties, including CNS MPO scores, we propose $\mathbf{7}$ and $\mathbf{1 0}$ as the most suitable compounds thus far to be subjected to further SAR studies aiming at developing CNS active Keap1 inhibitors.

In conclusion, this study constitutes the first side-by-side assessment of all major chemotypes of reported non-covalent small-molecule Keap1-Nrf2 PPI inhibitors. Based on our data, we question the legitimacy of a substantial proportion of the compounds (12-21) described in the literature and encourage researchers to critically reevaluate the use of these and only conclude on pharmacological mechanisms supported by orthogonal biochemical and biological assays. Furthermore, we demonstrated cross-assay activities for 1-11 and thereby identified the most promising genuine Keap1-binders with properties that warrant their use as pharmacological tool compounds or starting points for development of drug-like and potentially CNS active Keap1Nrf2 PPI inhibitors. 


\section{EXPERIMENTAL SECTION}

Chemistry. General Procedures. All chemicals used for synthesis were obtained from commercial suppliers and used without prior purification. ${ }^{1} \mathrm{H} N M R,{ }^{13} \mathrm{C} N M R$, and 2D-NMR spectra were recorded using either a $600 \mathrm{MHz}$ Bruker Avance III HD instrument equipped with a cryogenically cooled $5 \mathrm{~mm}$ dual probe or a $400 \mathrm{MHz}$ Bruker Avance III instrument equipped with a $5 \mathrm{~mm}$ broad band probe. Samples were dissolved in either DMSO- $d_{6}$ (VWR Chemicals, $99.80 \%$ D) or $\mathrm{CDCl}_{3}$ (Cambridge Isotope Laboratories, Inc., $99.8 \% \mathrm{D}$ ) and analyzed at $300 \mathrm{~K}$. TLC analyses were performed using TLC silica gel $60 \mathrm{~F}_{254}$ aluminum plates (Merck). LC-MS mass spectra were obtained with an Agilent 6410 Triple Quadrupole Mass Spectrometer instrument using electron spray ionization (ESI) coupled to an Agilent 1200 HPLC system (LC-MS) with a C18 reverse phase column (Zorbax Eclipse XBD-C18, $4.6 \mathrm{~mm} \times 50 \mathrm{~mm}$ ), autosampler and diode array detector, using a linear gradient of the binary solvent system of buffer A (milliQ $\mathrm{H}_{2} \mathrm{O}: \mathrm{MeCN}$ :formic acid, 95:5:0.1 v/v\%) to buffer B (milliQ $\mathrm{H}_{2} \mathrm{O}$ :MeCN:formic acid, 5:95:0.043 v/v\%) with a flow rate of $1 \mathrm{~mL} / \mathrm{min}$. During LC-MS analysis, evaporative light scattering (ELS) traces were obtained with a Sedere Sedex 85 Light Scattering Detector. Normal phase column chromatography was carried out using prepacked RediSep Rf silica flash cartridges on a CombiFlash ${ }^{\circledR} \mathrm{Rf}+$ apparatus. Preparative reverse phase HPLC was performed using an Agilent 1200 series HPLC preparative system with an Agilent Zorbax 300-SB-C18 column $(21.2 \times 250 \mathrm{~mm})$. Microwave-assisted synthesis was carried out using a Biotage ${ }^{\circledR}$ Initiator+ apparatus. All final compounds showed $\geq 95 \%$ purity by NMR and LC-MS as further described below.

Stock preparation, quality control, and quantification. The compounds were accurately weighed $( \pm$ $0.01 \mathrm{mg}$ ) and dissolved in $600 \mu \mathrm{L}$ DMSO- $d_{6}(\mathrm{VWR}$ Chemicals, $99.80 \% \mathrm{D}$ ) to make approximately $10 \mathrm{mM}$ stock solutions. In cases of solubility issues, the suspension was filtered using $0.22 \mu \mathrm{M}$ filters to obtain the highest possible stock concentration. The stock solutions were stored at $-60{ }^{\circ} \mathrm{C}$ before assaying. The stock solutions were quality controlled by ${ }^{1} \mathrm{H}$ NMR and ${ }^{13} \mathrm{C}$ NMR (and COSY, HSQC, and/or NOE NMR in relevant cases) and LCMS to confirm their identity and purity (>95\% by total ion current (TIC), $\mathrm{UV}_{214}$, and $\mathrm{UV}_{254},>95$ mol\% by ${ }^{1} \mathrm{H}$ NMR but excluding solvent residues). The NMR spectra can be found in the Supporting Information. The exact stock 
concentrations were determined by qHNMR, using $\mathrm{DMSO}_{2}$ (Sigma Aldrich, cat. no. 41867, 99.96\% pure by mass fraction) as an internal standard. $140 \mu \mathrm{L} \mathrm{DMSO}-d_{6}$ stock was diluted with $10 \mu \mathrm{L}$ of a $\mathrm{DMSO}_{2}$ stock with a known concentration $\left(C_{1 S}=45.79 \mathrm{mM}\right)$ and transferred to $3 \mathrm{~mm}$ standard NMR tubes. NMR spectra were acquired at a spectrometer frequency of $600 \mathrm{MHz}$, with $30^{\circ}$ angle of rotation pulse, collecting 16 scans and converting the FID to 65536 number of data points, with a $12 \mathrm{kHz}$ spectral width and recycle delay of $1.0 \mathrm{sec}$. The FIDs were zero-filled to twice the number of data points and exponentially multiplied with a line broadening factor of $0.3 \mathrm{~Hz}$. Spectra were processed by integrating the signal of the internal standard $(\delta 2.99 \mathrm{ppm}, \mathrm{s})$ and normalizing it to the number of protons $(6 \mathrm{H})$. All pure and assignable proton signals of the target analyte were then integrated, and the integrals normalized to the number of protons giving rise to the signal. The integral of the analyte $\left(\operatorname{Int}_{\mathrm{a}}\right)$ was then calculated by taking the average of all normalized analyte integrals. The concentration of the stocks $\left(C_{A}\right)$ were finally determined using the following equation: $C_{A}[m M]=\operatorname{lnt}_{a} \times C_{1 S} \times(10 \mu L / 150 \mu L) \times$ $(150 \mu \mathrm{L} / 140 \mu \mathrm{L})$.

\section{$(1 S, 2 R)-2-((S)-1-((1,3-D i o x o i s o i n d o l i n-2-y l)$ methyl)-1,2,3,4-tetrahydroisoquinoline-2-carbonyl)cyclohex-}

ane-1-carboxylic acid (3). Compound 3 was purified according to previously described procedure ${ }^{55}$ with no deviations. Starting from crude $\mathbf{2 4}, \mathbf{3}$ was obtained as a white solid $(0.012 \mathrm{~g}, 0.027 \mathrm{mmol}, 19 \%$ starting from $0.14 \mathrm{mmol} 23) . \mathrm{LC}-\mathrm{MS}: \mathrm{MS}(\mathrm{ESI}) \mathrm{m} / \mathrm{z} 447.3[\mathrm{M}+1]^{+}, \mathrm{t}_{\mathrm{R}}=3.34 \mathrm{~min} .{ }^{1} \mathrm{H}$ NMR $\left(600 \mathrm{MHz}, \mathrm{DMSO}-d_{6}\right) \delta 11.70(\mathrm{~s}, 1 \mathrm{H})$, 7.38-7.13 (m, 4H), $5.85(\mathrm{dd}, J=11.3,3.7 \mathrm{~Hz}, 1 \mathrm{H}), 4.00(\mathrm{dd}, J=14.2,11.4 \mathrm{~Hz}, 1 \mathrm{H}), 3.92(\mathrm{dd}, J=14.6,5.0 \mathrm{~Hz}, 1 \mathrm{H})$, $3.81(\mathrm{dd}, J=14.3,3.8 \mathrm{~Hz}, 1 \mathrm{H}), 3.61(\mathrm{ddd}, J=14.1,12.1,3.8 \mathrm{~Hz}, 1 \mathrm{H}), 3.28(\mathrm{td}, J=5.4,2.9 \mathrm{~Hz}, 1 \mathrm{H}), 2.91(\mathrm{ddd}, J=$ 17.0, 12.0, $5.4 \mathrm{~Hz}, 1 \mathrm{H}), 2.81(\mathrm{dt}, J=15.8,2.9 \mathrm{~Hz}, 1 \mathrm{H}), 2.23(\mathrm{dt}, J=11.6,4.7 \mathrm{~Hz}, 1 \mathrm{H}), 1.82(\mathrm{qd}, J=12.7,4.0 \mathrm{~Hz}$, 1H), 1.55 (dt, $J=13.0,4.2 \mathrm{~Hz}, 1 \mathrm{H}), 1.49(\mathrm{dd}, J=13.3,3.3 \mathrm{~Hz}, 1 \mathrm{H}), 1.36(\mathrm{ddt}, J=14.6,13.2,4.2 \mathrm{~Hz}, 1 \mathrm{H}), 1.32-1.20$ $(\mathrm{m}, 1 \mathrm{H}), 1.01-0.89(\mathrm{~m}, 1 \mathrm{H}), 0.88-0.78(\mathrm{~m}, 1 \mathrm{H}), 0.23(\mathrm{q}, J=12.9 \mathrm{~Hz}, 1 \mathrm{H}) .{ }^{13} \mathrm{C}$ NMR $\left(151 \mathrm{MHz}, \mathrm{DMSO}-d_{6}\right) \delta 175.34$, $174.08,168.11,135.43,134.87,134.23,131.98,129.64,127.64,127.47,126.80,123.55,49.87,42.75,41.09$, $39.39,36.53,29.06,27.56,24.96,24.30,20.98$. 
$N, N^{\prime}$-(naphthalene-1,4-diyl)bis(4-methoxybenzenesulfonamide) (4). The compound was synthesized according to previously described procedure ${ }^{22}$ with minor deviations. To a solution of $30(0.10 \mathrm{~g}, 0.63 \mathrm{mmol}$, 1.0 equiv) in toluene $(10 \mathrm{~mL})$ was added pyridine $(0.15 \mathrm{~mL}, 1.90 \mathrm{mmol}, 3.0$ equiv) and 4methoxybenzenesulfonyl chloride $(0.30 \mathrm{~g}, 1.43 \mathrm{mmol}, 2.3$ equiv). The reaction mixture was stirred under nitrogen at $100{ }^{\circ} \mathrm{C}$ for $3 \mathrm{~h}$, until TLC (EtOAc:heptane 1:1, $\mathrm{R}_{\mathrm{f}} 0.23$ ) showed complete conversion. The reaction mixture was then cooled to RT and the solvent removed by evaporation in vacuo. The residue was re-dissolved in EtOAc $(40 \mathrm{~mL})$, and the solution washed with water $(2 \times 50 \mathrm{~mL})$ and $2 \mathrm{M} \mathrm{HCl}(2 \times 50 \mathrm{~mL})$, dried over $\mathrm{Na}_{2} \mathrm{SO}_{4}$, and concentrated to dryness in vacuo. The crude was purified by flash chromatography (heptane:EtOAc, 0-100\% gradient) to furnish 4 as a slight yellow-colored powder $(0.042 \mathrm{~g}, 0.084 \mathrm{mmol}, 13 \%)$. In a larger scale synthesis (8.0 mmol), 4 was obtained in $23 \%$ yield. LC-MS: MS (ESI) $\mathrm{m} / \mathrm{z} 497.2[\mathrm{M}+1]^{+}, \mathrm{t}_{\mathrm{R}}=4.87-4.97 \mathrm{~min} .{ }^{1} \mathrm{H}$ NMR (DMSO-d $\left.d_{6}\right) \delta 10.01(\mathrm{~s}, 2 \mathrm{H}), 7.98-7.94(\mathrm{~m}, 2 \mathrm{H}), 7.57-7.53(\mathrm{~m}, 4 \mathrm{H}), 7.41-7.37(\mathrm{~m}, 2 \mathrm{H}), 7.01(\mathrm{~s}, 2 \mathrm{H}), 7.00-6.97(\mathrm{~m}$, 4H), $3.78(s, 6 H) .{ }^{13} \mathrm{C}$ NMR (DMSO- $\left.d_{6}\right) \delta 162.30,131.45,131.03,130.02,128.85,126.05,123.33,122.65,114.18$, 55.58.

2,2'-(naphthalene-1,4-diylbis(((4-methoxyphenyl)sulfonyl)azanediyl))diacetic acid (5). The compound was synthesized according to previously described procedure ${ }^{22}$ in two steps with minor deviations. For step 1 , a solution of 4 ( $0.30 \mathrm{~g}, 0.60 \mathrm{mmol}, 1.0$ equiv) in DMF $(5.0 \mathrm{~mL})$ was added $\mathrm{K}_{2} \mathrm{CO}_{3}(0.33 \mathrm{~g}, 2.41 \mathrm{mmol}, 4.0$ equiv) followed by ethyl bromoacetate $(0.22 \mathrm{~mL}, 2.01 \mathrm{mmol}, 3.3$ equiv). The reaction mixture was stirred at RT for $3 \mathrm{~h}$ until LC-MS showed complete conversion. The reaction mixture was then partitioned between EtOAc (40 mL) and water $(30 \mathrm{~mL})$, the aq. phase extracted with EtOAc $(2 \times 30 \mathrm{~mL})$, the combined organic phases washed with sat. brine $(2 \times 30 \mathrm{~mL})$, and concentrated to dryness in vacuo. The crude was purified by flash chromatography (heptane:EtOAc, 0-100\% gradient) to furnish diethyl 2,2'-(naphthalene-1,4-diylbis(((4-methoxyphenyl)sulfonyl)azanediyl))diacetate (5-I1) as a brown crystalline solid (0.36 g, $0.54 \mathrm{mmol}, 90 \%) .{ }^{1} \mathrm{H}$ NMR (DMSO- $\left.d_{6}\right) \delta$ $8.30(\mathrm{dd}, J=6.5,3.3 \mathrm{~Hz}, 1 \mathrm{H}), 8.18(\mathrm{dd}, J=6.5,3.3 \mathrm{~Hz}, 1 \mathrm{H}), 7.65-7.53(\mathrm{~m}, 6 \mathrm{H}), 7.19-7.06(\mathrm{~m}, 4 \mathrm{H}), 7.05(\mathrm{~d}, J=$ $2.1 \mathrm{~Hz}, 1 \mathrm{H}), 6.86(\mathrm{~s}, 1 \mathrm{H}), 4.59-4.37(\mathrm{~m}, 4 \mathrm{H}), 4.09-3.94(\mathrm{~m}, 4 \mathrm{H}), 3.89(\mathrm{~s}, 3 \mathrm{H}), 3.84(\mathrm{~s}, 3 \mathrm{H}), 1.12-1.01(\mathrm{~m}, 6 \mathrm{H})$. For step 2, to a solution of $\mathrm{NaOH}(1.50 \mathrm{~g}, 37.0 \mathrm{mmol}, 100$ equiv) in $\mathrm{MeOH}(10 \mathrm{~mL})$ and water $(10 \mathrm{~mL})$ was added 5- 
I1 ( $0.25 \mathrm{~g}, 0.37 \mathrm{mmol}, 1.0$ equiv). The reaction mixture was stirred at $65^{\circ} \mathrm{C}$ for $3 \mathrm{~h}$ (at least until a clear solution was obtained). The reaction mixture was adjusted to $\mathrm{pH} 2$ with $2 \mathrm{M} \mathrm{HCl}$, and the precipitate filtered, washed with water $(10 \mathrm{~mL})$, and dried in vacuo to furnish 5 as a light-brown solid $(0.15 \mathrm{~g}, 0.24 \mathrm{mmol}, 67 \%)$. LC-MS: MS (ESI) $\mathrm{m} / \mathrm{z} 613.2[\mathrm{M}-1]^{-}, 1227.2[2 \mathrm{M}-1]^{-}, \mathrm{t}_{\mathrm{R}}=4.61 \mathrm{~min} .{ }^{1} \mathrm{H} \mathrm{NMR}\left(\mathrm{DMSO}-\mathrm{d}_{6}\right) \delta 12.78(\mathrm{~s}, 2 \mathrm{H}), 8.29(\mathrm{dd}, J=6.5$, $3.3 \mathrm{~Hz}, 1 \mathrm{H}), 8.17(\mathrm{dd}, J=6.6,3.3 \mathrm{~Hz}, 1 \mathrm{H}), 7.57(\mathrm{~m}, 6 \mathrm{H}), 7.18-6.98(\mathrm{~m}, 5 \mathrm{H}), 6.89(\mathrm{~s}, 1 \mathrm{H}), 4.40(\mathrm{~m}, 4 \mathrm{H}), 3.86(\mathrm{~d}, J=$ $19.7 \mathrm{~Hz}, 6 \mathrm{H}$ ). ${ }^{13} \mathrm{C}$ NMR (DMSO- $\left.d_{6}\right) \delta 169.83,162.86,137.03,132.94,130.07,129.85,129.53,128.99,126.58$, $126.28,124.63,114.25,55.72,53.20,39.84$.

2,2'-(naphthalene-1,4-diylbis(((4-methoxyphenyl)sulfonyl)azanediyl))diacetamide (6). The compound was synthesized according to previously described procedure ${ }^{34}$ with minor deviations. To a solution of $\mathbf{4}$ ( $0.100 \mathrm{~g}, 0.20 \mathrm{mmol}, 1.0$ equiv) in dry DMF $(2.0 \mathrm{~mL})$ was added $\mathrm{K}_{2} \mathrm{CO}_{3}(0.083 \mathrm{~g}, 0.60 \mathrm{mmol}, 3.0$ equiv) followed by 2-bromoacetamide $(0.12 \mathrm{~g}, 0.90 \mathrm{mmol}, 4.5$ equiv). The reaction mixture was stirred at RT for 5 days until LCMS showed complete conversion. The reaction mixture was then quenched with water $(25 \mathrm{~mL})$, acidified to pH 5 with $2 \mathrm{M} \mathrm{HCl}$, extracted with EtOAc $(3 \times 25 \mathrm{~mL})$, and the combined organic phases concentrated to dryness in vacuo. The crude was purified by preparative HPLC (buffer A $\mathrm{H}_{2} \mathrm{O}$ :MeCN:TFA 95:5:0.1, buffer B $\mathrm{H}_{2} \mathrm{O}: \mathrm{MeCN}: T F A$ 5:95:0.1, 0-50\% gradient) to furnish 6 as a white crystalline solid (0.035 g, $\left.0.057 \mathrm{mmol}, 29 \%\right)$. LC-MS: MS (ESI) m/z $1225.3[2 \mathrm{M}+1]^{+}, \mathrm{t}_{\mathrm{R}}=4.10 \mathrm{~min} .{ }^{1} \mathrm{H}$ NMR (DMSO- $\left.d_{6}\right) \delta 8.29(\mathrm{dd}, \mathrm{J}=6.6,3.3 \mathrm{~Hz}, 1 \mathrm{H}), 8.18(\mathrm{dd}$, $J=6.5,3.3 \mathrm{~Hz}, 1 \mathrm{H}), 7.65-7.49(\mathrm{~m}, 6 \mathrm{H}), 7.29(\mathrm{~d}, \mathrm{~J}=18.3 \mathrm{~Hz}, 2 \mathrm{H}), 7.19-6.87(\mathrm{~m}, 7 \mathrm{H}), 6.82(\mathrm{~s}, 1 \mathrm{H}), 4.38-4.11(\mathrm{~m}$, 4H), $3.86(d, J=20.7 \mathrm{~Hz}, 6 \mathrm{H}) .{ }^{13} \mathrm{C}$ NMR (DMSO-d $)$ $\delta 168.91,162.94,137.03,133.13,133.01,130.34,130.11$, $129.57,129.18,126.66,126.49,126.14,124.83,124.69,118.21,114.33,114.27,79.22,67.14,55.85,55.82$, $54.96,54.15,54.03$.

(S)-1-(4-((2,3,5,6-tetramethylphenyl)sulfonamido)naphthalen-1-yl)pyrrolidine-3-carboxylic acid (7). The compound was synthesized according to previously described procedure ${ }^{36}$ with some deviations. To a solution of 33 (0.097 g, $0.38 \mathrm{mmol}$ assumed, 1.0 equiv) in DCM $(2.0 \mathrm{~mL})$ was added pyridine $(0.032 \mathrm{~mL}, 0.40 \mathrm{mmol}$, 1.05 equiv) and 2,3,5,6-tetramethylbenzene-sulfonyl chloride (0.093 g, $0.40 \mathrm{mmol}, 1.05$ equiv), and the reaction mixture stirred at RT for $16 \mathrm{~h}$. The reaction mixture was then diluted with water $(3 \mathrm{~mL})$, the $\mathrm{pH}$ adjusted to 
2 with $2 \mathrm{M} \mathrm{HCl}$ and the compound extracted with DCM $(3 \times 10 \mathrm{~mL})$. The combined organic phases were dried over $\mathrm{Na}_{2} \mathrm{SO}_{4}$, filtered, and concentrated to dryness in vacuo. The crude was purified by preparative HPLC (buffer $\mathrm{A} \mathrm{H}_{2} \mathrm{O}$ :MeCN:TFA 95:5:0.1, buffer $\mathrm{B} \mathrm{H}_{2} \mathrm{O}$ :MeCN:TFA 5:95:0.1, 0-100\% gradient) to furnish 7 as a blue solid (0.027 g, $0.060 \mathrm{mmol}, 16 \%$ over two steps). LC-MS: MS (ESI) m/z $453.2[\mathrm{M}+1]^{+}, \mathrm{t}_{\mathrm{R}}=3.50 \mathrm{~min} .{ }^{1} \mathrm{H} \mathrm{NMR}(600 \mathrm{MHz}$, DMSO-d $\left.d_{6}\right) \delta 9.77(\mathrm{~s}, 1 \mathrm{H}), 8.13(\mathrm{dd}, J=8.0,1.8 \mathrm{~Hz}, 1 \mathrm{H}), 8.04(\mathrm{dt}, J=9.1,1.7 \mathrm{~Hz}, 1 \mathrm{H}), 7.44(\mathrm{tt}, J=8.3,5.8 \mathrm{~Hz}, 2 \mathrm{H})$, $7.18(\mathrm{~s}, 1 \mathrm{H}), 6.94-6.82(\mathrm{~m}, 2 \mathrm{H}), 3.50$ (under water peak), $3.32(\mathrm{dd}, J=9.5,7.8 \mathrm{~Hz}, 1 \mathrm{H}), 3.24(\mathrm{tq}, J=5.8,3.3$, $2.9 \mathrm{~Hz}, 2 \mathrm{H}), 3.16(\mathrm{tt}, J=8.2,6.1 \mathrm{~Hz}, 1 \mathrm{H}), 2.21(\mathrm{~m}, 14 \mathrm{H}) .{ }^{13} \mathrm{C}$ NMR $\left(151 \mathrm{MHz}, \mathrm{DMSO}-d_{6}\right) \delta 145.85,139.20,135.29$, $135.02,134.66,134.62,131.88,127.94,125.71,125.09,124.85,124.25,123.83,111.49,55.04,51.62,41.88$, $27.73,20.42,17.80$.

\section{5-((4-ethoxyphenyl)sulfonamido)-1-((4-ethoxyphenyl)sulfonyl)- $\mathrm{N}$-hydroxy-1H-benzo[g]indole-3-carbox-}

amide (8). The compound was synthesized in two steps according to previously described procedure ${ }^{38}$ with minor deviations. For step 1, a solution of $35(0.20 \mathrm{~g}, 0.38 \mathrm{mmol}, 1.0$ equiv) in dry toluene $(10 \mathrm{~mL})$ were added ethyl acetoacetate $\left(0.049 \mathrm{~mL}, 0.38 \mathrm{mmol}, 1.0\right.$ equiv) and $\mathrm{Et}_{3} \mathrm{~N}(0.20 \mathrm{~mL}, 1.42 \mathrm{mmol}, 3.7$ equiv). The reaction mixture was stirred at RT for $2 \mathrm{~h}$, until TLC (heptane:EtOAc 1:1, $R_{f} 0.22$ ) showed complete reaction. The reaction mixture was then added $10 \%$ aq. $\mathrm{HCl}(10 \mathrm{~mL})$, extracted with EtOAc $(2 \times 10 \mathrm{~mL})$, the combined organic phases washed with sat. brine $(10 \mathrm{~mL})$, dried over $\mathrm{Na}_{2} \mathrm{SO}_{4}$, and concentrated to dryness in vacuo. The crude was purified by flash chromatography (heptane:EtOAc, 0-45\% gradient) to furnish ethyl 2-(1,4-bis((4ethoxyphenyl)sulfonamido)naphthalen-2-yl)-3-oxobutanoate (8-I1) as a light-brown solid (0.12 g, $0.18 \mathrm{mmol}$, 48\%). LC-MS: MS (ESI) m/z $653.2[\mathrm{M}-1]^{-}, \mathrm{t}_{\mathrm{R}}=3.47-3.74 \mathrm{~min}$. For step 2, a solution of 8-11 (0.050 g, $0.076 \mathrm{mmol}$, 1.0 equiv) in $\mathrm{AcOH}(1.5 \mathrm{~mL})$ was added a solution of hydroxylamine hydrochloride $(0.032 \mathrm{~g}, 0.97 \mathrm{mmol}$, 12 equiv) in water $(0.5 \mathrm{~mL})$ and the reaction mixture stirred at $80^{\circ} \mathrm{C}$ for $2 \mathrm{~h}$, until LC-MS showed complete reaction. The reaction mixture was then added water $(5 \mathrm{~mL})$, the precipitate collected by filtration, and dried in vacuo to furnish the pure product as a light-brown solid $(0.022 \mathrm{~g}, 0.035 \mathrm{mmol}, 47 \%)$. LC-MS: MS (ESI) m/z 622.2 $[\mathrm{M}-1]^{-}, 1245.4[2 \mathrm{M}-1]^{-}, \mathrm{t}_{\mathrm{R}}=3.4-4.1 \mathrm{~min}$ (broad peak). ${ }^{1} \mathrm{H}$ NMR (DMSO- $\left.d_{6}\right) \delta 10.09(\mathrm{~s}, 1 \mathrm{H}), 9.42(\mathrm{~s}, 1 \mathrm{H}), 8.36(\mathrm{~d}, J$ $=8.5 \mathrm{~Hz}, 1 \mathrm{H}), 8.07(\mathrm{~d}, J=8.3 \mathrm{~Hz}, 1 \mathrm{H}), 7.64-7.56(\mathrm{~m}, 2 \mathrm{H}), 7.52(\mathrm{ddd}, J=8.3,6.8,1.4 \mathrm{~Hz}, 1 \mathrm{H}), 7.45(\mathrm{ddd}, J=8.2$, 
6.8, 1.3 Hz, 1H), 7.12-7.06 (m, 2H), 7.07-7.01 (m, 2H), $6.85(\mathrm{~s}, 1 \mathrm{H}), 6.84-6.77(\mathrm{~m}, 2 \mathrm{H}), 4.07(\mathrm{qd}, J=6.9,2.5 \mathrm{~Hz}$, 4H), $1.54(\mathrm{~s}, 3 \mathrm{H}), 1.34(\mathrm{dt}, J=23.0,7.0 \mathrm{~Hz}, 6 \mathrm{H}) .{ }^{13} \mathrm{C}$ NMR (DMSO- $\left.d_{6}\right) \delta 170.18,161.72,161.37,157.68,133.12$, $131.69,131.01,130.72,128.96,128.70,128.03,127.09,126.19,125.66,125.56,123.81,122.95,114.71$, $114.07,92.25,63.71,63.64,14.51,14.38,11.13$.

\section{3-(7-methoxy-1-methyl-1H-benzo[d][1,2,3]triazol-5-yl)-3-(4-methyl-3-(((R)-4-methyl-1,1-dioxido-3,4-}

dihydro-2H-benzo[b][1,4,5]oxathiazepin-2-yl)methyl)phenyl)propanoic acid (9). The compound was synthesized in two steps according to previously described procedure ${ }^{27}$ with minor deviations. To a solution of $\mathbf{5 5}$ (0.10 g, $0.28 \mathrm{mmol}, 1.0$ equiv) in THF $(3.3 \mathrm{~mL})$ was added 57 (0.09 g, $0.42 \mathrm{mmol}, 1.5$ equiv), $\mathrm{PPh}_{3}(0.15 \mathrm{~g}$, $0.56 \mathrm{mmol}, 2.0$ equiv), and a solution of diisopropyl azodicarboxylate (DIAD, $111.0 \mu \mathrm{L}, 0.56 \mathrm{mmol}, 2.0$ equiv) in THF (1.1 mL). The resulting reaction mixture was stirred at RT for $30 \mathrm{~min}$. The reaction mixture was then evaporated in vacuo. The crude was purified by flash chromatography (heptane:EtOAc, $0-100 \%$ gradient) to afford methyl 3-(7-methoxy-1-methyl-1H-benz-o[d][1,2,3]triazol-5-yl)-3-(4-methyl-3-(((R)-4-methyl-1,1-dioxido-3,4dihydro-2H-benzo[b][1,4,5]oxathiazepin-2-yl)methyl)phenyl)propanoate (9-I1) (0.10 g, 0.18 mmol, 65\%). To 9$11(0.10 \mathrm{~g}, 0.18 \mathrm{mmol}, 1.0$ equiv) was added $\mathrm{MeOH}(3.3 \mathrm{~mL})$ and then $\mathrm{NaOH}(2 \mathrm{M}, 0.70 \mathrm{~mL}, 1.40 \mathrm{mmol}$, 7.8 equiv). The reaction mixture was heated to $80^{\circ} \mathrm{C}$ for $40 \mathrm{~min}$. The resulting reaction mixture was acidified with $\mathrm{HCl}(1 \mathrm{M})$ to $\mathrm{pH}$ 3, extracted with EtOAc $(3 \times 5 \mathrm{~mL})$, washed with brine $(5 \mathrm{~mL})$, and concentrated in vacuo. The crude was first purified by preparative HPLC (buffer $\mathrm{A} \mathrm{H}_{2} \mathrm{O}: \mathrm{MeCN}: T F A$ 95:5:0.1, buffer B $\mathrm{H}_{2} \mathrm{O}$ :MeCN:TFA 5:95:0.1, 0-100\% gradient) followed by purification by flash chromatography (heptane:EtOAc, 0-100\% gradient) to furnish 9 as a white solid $(0.07 \mathrm{~g}, 0.13 \mathrm{mmol}, 70 \%)$. LC-MS: MS (ESI) m/z $551.2[\mathrm{M}+1]^{+} .{ }^{1} \mathrm{H}$ NMR $\left(600 \mathrm{MHz}, \mathrm{DMSO}-d_{6}\right) \delta 12.10(\mathrm{~s}, 1 \mathrm{H}), 7.77(\mathrm{ddd}, J=7.8,2.5,1.7 \mathrm{~Hz}, 1 \mathrm{H}), 7.65(\mathrm{tt}, J=7.6,1.7 \mathrm{~Hz}, 1 \mathrm{H}), 7.44(\mathrm{dd}, J=$ 7.1, 1.0 Hz, 1H), 7.36 (tdd, $J=7.6,3.7,2.2 \mathrm{~Hz}, 2 \mathrm{H}), 7.32-7.24(\mathrm{~m}, 2 \mathrm{H}), 7.11(\mathrm{~d}, J=7.8 \mathrm{~Hz}, 1 \mathrm{H}), 6.91(\mathrm{dd}, J=14.2$, $1.1 \mathrm{~Hz}, 1 \mathrm{H}), 4.50(\mathrm{td}, J=7.9,4.6 \mathrm{~Hz}, 1 \mathrm{H}), 4.46-4.35(\mathrm{~m}, 2 \mathrm{H}), 4.33(\mathrm{~d}, J=4.0 \mathrm{~Hz}, 3 \mathrm{H}), 3.92(\mathrm{~d}, J=6.7 \mathrm{~Hz}, 3 \mathrm{H}), 3.81$ (d, $J=14.0 \mathrm{~Hz}, 1 \mathrm{H}), 3.61(\mathrm{ddd}, J=15.4,10.3,5.3 \mathrm{~Hz}, 1 \mathrm{H}), 3.14-3.03(\mathrm{~m}, 2 \mathrm{H}), 2.78(\mathrm{ddd}, J=48.4,15.3,1.4 \mathrm{~Hz}$, $1 \mathrm{H}), 2.24(\mathrm{~d}, J=6.1 \mathrm{~Hz}, 3 \mathrm{H}), 1.14(\mathrm{dd}, J=59.0,6.4 \mathrm{~Hz}, 3 \mathrm{H})$. 


\section{1-(3-((cis)-3-(2-Butylpyrrolidine-1-carbonyl)cyclohexyl)phenyl)-5-cyclopropyl-1H-pyrazole-4-carboxylic}

acid (10). The compound was synthesized in two steps according the previously described procedure ${ }^{39}$ with some deviations. For step 1, a solution of $43(0.21 \mathrm{~g}, 0.54 \mathrm{mmol}, 1.0$ equiv) in dry DCM $(4.0 \mathrm{~mL})$ was added HATU (0.25 g, $0.65 \mathrm{mmol}, 1.20$ equiv) and DIPEA ( $0.44 \mathrm{~mL}, 1.35 \mathrm{mmol}, 2.50$ equiv) at $0{ }^{\circ} \mathrm{C}$. The solution was allowed to stir at $0{ }^{\circ} \mathrm{C}$ for $30 \mathrm{~min}$. Then, 2-butylpyrrolidine hydrochloride $(0.11 \mathrm{~g}, 0.65 \mathrm{mmol}, 1.2$ equiv) was added and the reaction mixture allowed to stir at RT for $18 \mathrm{~h}$, until LC-MS showed complete reaction. The reaction mixture was then diluted with $\mathrm{DCM}(20 \mathrm{~mL})$, and the solution washed with sat. $\mathrm{NaHCO}_{3}(15 \mathrm{~mL})$, dried over $\mathrm{Na}_{2} \mathrm{SO}_{4}$, filtered, and concentrated to dryness in vacuo. The crude was purified by flash chromatography (heptane:EtOAc, $\quad 0-100 \%$ gradient) to furnish ethyl 1-(3-((1S,3R)-3-(2-butylpyrrolidine-1carbonyl)cyclohexyl)phenyl)-5-cyclopropyl-1H-pyrazole-4-carboxylate (10-I1) as a colorless sticky oil (0.12 g, $0.24 \mathrm{mmol}, 44 \%)$. LC-MS: MS (ESI) m/z $492.3[\mathrm{M}+1]^{+}, \mathrm{t}_{\mathrm{R}}=4.37 \mathrm{~min} .{ }^{1} \mathrm{H} \mathrm{NMR}\left(400 \mathrm{MHz}, \mathrm{DMSO}-d_{6}\right) \delta 7.96(\mathrm{~s}, 1 \mathrm{H})$, 7.51-7.42 (m, 2H), $7.39(\mathrm{dq}, J=8.0,1.6 \mathrm{~Hz}, 1 \mathrm{H}), 7.35$ (ddt, J = 7.4, 2.9, $1.4 \mathrm{~Hz}, 1 \mathrm{H}), 4.24(\mathrm{q}, J=7.1 \mathrm{~Hz}, 2 \mathrm{H}), 3.98-$ $3.80(\mathrm{~m}, 1 \mathrm{H}), 3.55-3.43(\mathrm{~m}, 2 \mathrm{H}), 2.72(\mathrm{~d}, J=11.9 \mathrm{~Hz}, 1 \mathrm{H}), 2.56(\mathrm{~s}, 1 \mathrm{H}), 2.17-2.05(\mathrm{~m}, 1 \mathrm{H}), 1.98-1.66(\mathrm{~m}, 9 \mathrm{H})$, $1.70-1.34(\mathrm{~m}, 4 \mathrm{H}), 1.30(\mathrm{t}, J=7.1 \mathrm{~Hz}, 4 \mathrm{H}), 1.29-1.09(\mathrm{~m}, 3 \mathrm{H}), 1.00-0.70(\mathrm{~m}, 5 \mathrm{H}), 0.47(\mathrm{dd}, J=5.9,1.5 \mathrm{~Hz}, 2 \mathrm{H})$. ${ }^{13} \mathrm{C}$ NMR $\left(101 \mathrm{MHz}\right.$, DMSO- $\left.d_{6}\right) \delta 172.64,162.30,147.92,146.91,141.40,139.13,128.84,126.74,123.64$, $122.82,113.46,59.52,56.16,45.91,42.61,42.51,42.35,41.97,36.61,35.66,32.89,32.39,32.32,28.56,28.44$, $27.88,25.25,23.67,22.17,14.25,13.95,13.90,8.12,7.02$. For step 2 , a solution of $10-11$ (0.12 $\mathrm{g}, 0.24 \mathrm{mmol}$, 1.0 equiv) in $i-\mathrm{PrOH}(4.0 \mathrm{~mL})$ was added $\mathrm{NaOH}(1.2 \mathrm{~mL} 2 \mathrm{M}$ aq. solution, $2.40 \mathrm{mmol}, 10.0$ equiv), and the reaction mixture stirred at RT for $72 \mathrm{~h}$, until LC-MS showed complete reaction. The reaction mixture was then diluted with EtOAc $(15 \mathrm{~mL})$ and washed with water $(10 \mathrm{~mL})$. The aq. phase was acidified with $1 \mathrm{M} \mathrm{HCl}$ and extracted with EtOAc $(2 \times 15 \mathrm{~mL})$. The combined organic phases were dried over $\mathrm{Na}_{2} \mathrm{SO}_{4}$, filtered, and concentrated in vacuo. The crude was purified by preparative HPLC (buffer $\mathrm{A} \mathrm{H}_{2} \mathrm{O}: \mathrm{MeCN}$ :TFA 95:5:0.1, buffer B $\mathrm{H}_{2} \mathrm{O}: \mathrm{MeCN}$ :TFA 5:95:0.1, 0-100\% gradient) to furnish 10 as a white solid (0.045 g, $0.097 \mathrm{mmol}, 41 \%)$. LC-MS: MS (ESI) m/z $464.3[\mathrm{M}+1]^{+}, 927.6[2 \mathrm{M}+1]^{+}, \mathrm{t}_{\mathrm{R}}=3.65-3.82 \mathrm{~min}$. (two peaks). ${ }^{1} \mathrm{H}$ NMR $\left(600 \mathrm{MHz}, \mathrm{DMSO}-d_{6}\right) \delta 7.92(\mathrm{~s}, 1 \mathrm{H}), 7.44$ $(\mathrm{td}, J=7.5,2.8 \mathrm{~Hz}, 2 \mathrm{H}), 7.41-7.37(\mathrm{~m}, 1 \mathrm{H}), 7.35(\mathrm{~d}, J=6.6 \mathrm{~Hz}, 1 \mathrm{H}), 3.98-3.81(\mathrm{~m}, 1 \mathrm{H}), 3.56-3.42(\mathrm{~m}, 1 \mathrm{H}), 3.37-$ 
$3.16(\mathrm{~m}, 0 \mathrm{H}), 2.80-2.64(\mathrm{~m}, 1 \mathrm{H}), 2.60-2.53(\mathrm{~m}, 1 \mathrm{H}), 2.09(\mathrm{td}, J=5.5,2.8 \mathrm{~Hz}, 1 \mathrm{H}), 1.95-1.66(\mathrm{~m}, 7 \mathrm{H}), 1.70-1.10$ $(\mathrm{m}, 8 \mathrm{H}), 0.94-0.76(\mathrm{~m}, 5 \mathrm{H}), 0.51$ (hept, $J=4.3,3.9 \mathrm{~Hz}, 2 \mathrm{H}) .{ }^{13} \mathrm{C}$ NMR $\left(151 \mathrm{MHz}, \mathrm{DMSO}-d_{6}\right) \delta 163.86,146.90$, $141.83,139.27,128.85,126.68,123.75,122.93,113.99,56.20,56.18,45.93,44.91,42.61,42.36,42.10,41.98$, $41.95,41.86,40.06,36.63,35.69,32.89,32.40,32.32,28.57,28.46,27.90,27.58,25.26,23.68,23.65,22.19$, $22.15,21.99,13.92,8.10,7.04$.

2-((5-((2,4-dimethylphenyl)sulfonyl)-6-oxo-1,6-dihydropyrimidin-2-yl)thio)-N-(2-(trifluoromethyl)phen-

yl)acetamide (11). The compound was synthesized according to a previously described general procedure ${ }^{87}$ with some deviations. A solution of 47 ( $0.12 \mathrm{~g}, 0.40 \mathrm{mmol}, 1.00$ equiv), 49 ( $0.15 \mathrm{~g}, 0.52 \mathrm{mmol}, 1.30$ equiv), and dry $\mathrm{Et}_{3} \mathrm{~N}\left(0.33 \mathrm{~mL}, 2.40 \mathrm{mmol}, 6.00\right.$ equiv) in dry DMF $(2.0 \mathrm{~mL})$ was stirred at $80{ }^{\circ} \mathrm{C}$ for $1.5 \mathrm{~h}$, until LC-MS showed complete reaction. The reaction mixture was then cooled, followed by addition of $2 \mathrm{M} \mathrm{HCl}(10 \mathrm{~mL})$, extraction with EtOAc $(3 \times 10 \mathrm{~mL})$. The combined organic phases were washed with brine $(2 \times 10 \mathrm{~mL})$, dried over $\mathrm{Na}_{2} \mathrm{SO}_{4}$, filtered and concentrated to dryness in vacuo. The crude was purified by flash chromatography (heptane:EtOAc, 0-100\%) to furnish 11 as a brown solid (0.11 g, $0.22 \mathrm{mmol}, 55 \%)$. LC-MS: MS (ESI) m/z 498.2 $[\mathrm{M}+1]^{+}, \mathrm{t}_{\mathrm{R}}=3.17 \mathrm{~min} .{ }^{1} \mathrm{H}$ NMR $\left(600 \mathrm{MHz}, \mathrm{DMSO}-\mathrm{d}_{6}\right) \delta 9.92(\mathrm{~s}, 1 \mathrm{H}), 8.45(\mathrm{~s}, 1 \mathrm{H}), 7.90(\mathrm{~d}, J=8.1 \mathrm{~Hz}, 1 \mathrm{H}), 7.73(\mathrm{dd}$, $J=7.9,1.5 \mathrm{~Hz}, 1 \mathrm{H}), 7.70-7.62(\mathrm{~m}, 1 \mathrm{H}), 7.56(\mathrm{~d}, J=8.1 \mathrm{~Hz}, 1 \mathrm{H}), 7.44(\mathrm{t}, J=7.7 \mathrm{~Hz}, 1 \mathrm{H}), 7.22(\mathrm{dd}, J=8.1,1.7 \mathrm{~Hz}$, 1H), 7.17-7.07 (m, 1H), $4.08(\mathrm{~s}, 2 \mathrm{H}), 2.37(\mathrm{~s}, 3 \mathrm{H}), 2.32(\mathrm{~s}, 3 \mathrm{H}) .{ }^{13} \mathrm{C}$ NMR (151 MHz, DMSO-d 6 ) $\delta$ 169.54, 167.12, $155.58,143.67,136.69,135.15,135.07,133.04,132.64,130.91,129.26,126.60,126.56,126.24,126.20$, $124.38,122.57,120.75,34.42,20.79,19.25$.

1-(3-iodophenyl)-4-(3-nitrophenyl)-1H-1,2,3-triazole (12). The compound was synthesized according to previously described procedure ${ }^{58}$ with minor deviations. In a microwave vial was added a suspension of $\mathbf{5 8}$ (0.040 g, $0.27 \mathrm{mmol}, 1.00$ equiv) in $t-\mathrm{BuOH}(1.1 \mathrm{~mL})$. An aq. solution of $\mathrm{CuSO}_{4} \cdot 5 \mathrm{H}_{2} \mathrm{O}(0.54 \mathrm{~mL} 4.12 \mathrm{mg} / \mathrm{mL}$ sol., $0.0090 \mathrm{mmol}, 0.033$ equiv), an aq. solution of L-ascorbic acid $(0.55 \mathrm{~mL} 8.7 \mathrm{mg} / \mathrm{mL}$ sol., $0.027 \mathrm{mmol}, 0.10$ equiv), and 59 ( $0.067 \mathrm{~g}, 0.27 \mathrm{mmol}, 1.00$ equiv) were then added. The vial was capped and the mixture subjected to microwave irradiation at $130{ }^{\circ} \mathrm{C}$ for $30 \mathrm{~min}$ (pre-stirring for $30 \mathrm{~s}$ ), until TLC (heptane:EtOAc $1: 1, R_{f} 0.66$ ) showed complete reaction. The reaction mixture was then diluted in water $(5 \mathrm{~mL})$, filtered, and the residue further 
washed with water $(2 \times 5 \mathrm{~mL})$ and then dried in vacuo. The residual solid on the filter paper/in the microwave vial was recovered by dissolution in DCM and the solution concentrated in vacuo to give a solid, which was pooled with the filtered crude. The crude was purified by flash chromatography (heptane:EtOAc, $0-40 \%$ ) to furnish 12 as a light yellow powder $(0.032 \mathrm{~g}, 0.082 \mathrm{mmol}, 29 \%)$. LC-MS: MS (ESI) m/z $393.0[\mathrm{M}+1]^{+}, \mathrm{t}_{\mathrm{R}}=$ 6.38 min. ${ }^{1} \mathrm{H}$ NMR $\left(400 \mathrm{MHz}, \mathrm{DMSO}-d_{6}\right) \delta 9.64(\mathrm{~s}, 1 \mathrm{H}), 8.74(\mathrm{t}, J=2.0 \mathrm{~Hz}, 1 \mathrm{H}), 8.39(\mathrm{dt}, J=7.9,1.2 \mathrm{~Hz}, 1 \mathrm{H}), 8.35$ (t, $J=1.9 \mathrm{~Hz}, 1 \mathrm{H}$ ), 8.25 (ddd, $J=8.2,2.4,1.0 \mathrm{~Hz}, 1 \mathrm{H}$ ), 8.03 (ddd, $J=8.1,2.2,0.9 \mathrm{~Hz}, 1 \mathrm{H}$ ), $7.90(\mathrm{dt}, J=7.9,1.2 \mathrm{~Hz}$, 1H), $7.83(t, J=8.0 \mathrm{~Hz}, 1 \mathrm{H}), 7.44(\mathrm{t}, J=8.0 \mathrm{~Hz}, 1 \mathrm{H}) .{ }^{13} \mathrm{C}$ NMR $\left(101 \mathrm{MHz}, \mathrm{DMSO}-d_{6}\right) \delta 148.41,145.38,137.52$, $137.30,131.84,131.75,131.34,130.78,128.05,122.88,121.15,119.64,119.33,95.49$.

2-(3-((3-(5-(Furan-2-yl)-1,3,4-oxadiazol-2-yl)ureido)methyl)phenoxy)acetic acid (14). The compound was synthesized according to previously described procedure ${ }^{42}$ with minor deviations. To a solution of 61 (0.15 g, $0.83 \mathrm{mmol}, 1.34$ equiv) and $62(0.20 \mathrm{~g}, 0.62 \mathrm{mmol}, 1.00$ equiv) in MeCN (10 mL) was added DIPEA (0.24 mL, $1.41 \mathrm{mmol}, 2.27$ equiv). The reaction mixture was stirred at $60^{\circ} \mathrm{C}$ for $16 \mathrm{~h}$, until TLC (DCM:MeOH:AcOH 20:4:1, $\left.R_{f} 0.45\right)$ showed complete reaction. The reaction mixture was then concentrated to dryness in vacuo. The crude was purified by purified by flash chromatography (heptane:EtOAc, $0-20 \%)$ to furnish 14 as a white solid $(0.10 \mathrm{~g}$, $0.28 \mathrm{mmol}, 31 \%) . \mathrm{LC}-\mathrm{MS}: \mathrm{MS}(\mathrm{ESI}) \mathrm{m} / \mathrm{z} 359.2[\mathrm{M}+1]^{+}, 717.2[2 \mathrm{M}+1]^{+}, \mathrm{t}_{\mathrm{R}}=2.33 \mathrm{~min} .{ }^{1} \mathrm{H}$ NMR $(400 \mathrm{MHz}, \mathrm{DMSO}-$ $\left.d_{6}\right) \delta 12.97(\mathrm{~s}, 1 \mathrm{H}), 11.04(\mathrm{~s}, 1 \mathrm{H}), 8.01(\mathrm{~d}, J=1.8 \mathrm{~Hz}, 1 \mathrm{H}), 7.98(\mathrm{~d}, J=6.0 \mathrm{~Hz}, 1 \mathrm{H}), 7.26(\mathrm{t}, J=7.9 \mathrm{~Hz}, 1 \mathrm{H}), 7.18(\mathrm{~d}, J$ $=3.5 \mathrm{~Hz}, 1 \mathrm{H}), 6.93(\mathrm{~d}, J=7.6 \mathrm{~Hz}, 1 \mathrm{H}), 6.90(\mathrm{t}, J=2.1 \mathrm{~Hz}, 1 \mathrm{H}), 6.80(\mathrm{dd}, J=8.2,2.7 \mathrm{~Hz}, 1 \mathrm{H}), 6.77(\mathrm{dd}, J=3.6$, $1.8 \mathrm{~Hz}, 1 \mathrm{H}), 4.66(\mathrm{~s}, 2 \mathrm{H}), 4.39(\mathrm{~d}, J=5.9 \mathrm{~Hz}, 2 \mathrm{H}) .{ }^{13} \mathrm{C}$ NMR (101 MHz, DMSO) $\delta 170.59,158.65,158.33,146.88$, $141.45,138.87,129.91,120.30,114.14,113.79,112.99,112.92,64.88,43.48$.

3-(1H-benzo[d]imidazol-5-yl)-5-(4-fluorophenyl)-1,2,4-oxadiazole (16). The compound was synthesized according to a previously described procedure ${ }^{44}$ with some deviations. To a solution of 4 -fluorobenzoic acid (0.25 g, $1.60 \mathrm{mmol}, 1.00$ equiv) in DMF (1.0 mL) was added carbonyldiimidazole (0.26 $\mathrm{g}, 1.60 \mathrm{mmol}$, 1.00 equiv), and the solution was stirred at RT for $24 \mathrm{~h}$. Then 64 ( $0.29 \mathrm{~g}, 1.60 \mathrm{mmol}$ assumed, 1.00 equiv) was added and the reaction mixture stirred at $155^{\circ} \mathrm{C}$ for $72 \mathrm{~h}$, until LC-MS showed complete reaction. The reaction mixture was then concentrated in vacuo, redissolved in EtOAc $(30 \mathrm{~mL})$ and sat. $\mathrm{NaHCO}_{3}(30 \mathrm{~mL})$. The aq. layer 
was extracted with EtOAc $(3 \times 30 \mathrm{~mL})$, and the combined organic layers dried over $\mathrm{Na}_{2} \mathrm{SO}_{4}$, filtered, and concentrated to dryness in vacuo. The crude was purified by flash chromatography (heptane:EtOAc, $0-100 \%$ ) to furnish 16 as a white solid $(0.20 \mathrm{~g}, 0.71 \mathrm{mmol}, 45 \%)$. LC-MS: MS (ESI) m/z $281.1[\mathrm{M}+1]^{+}, \mathrm{t}_{\mathrm{R}}=2.43 \mathrm{~min} .{ }^{1} \mathrm{H} \mathrm{NMR}$ $\left(600 \mathrm{MHz}, \mathrm{DMSO}-d_{6}\right) \delta 12.77(\mathrm{~s}, 1 \mathrm{H}), 8.40(\mathrm{~s}, 1 \mathrm{H}), 8.38(\mathrm{~s}, 1 \mathrm{H}), 8.32-8.25(\mathrm{~m}, 3 \mathrm{H}), 7.95(\mathrm{dd}, J=25.3,8.4 \mathrm{~Hz}, 1 \mathrm{H})$, $7.84(\mathrm{~d}, J=8.4 \mathrm{~Hz}, 1 \mathrm{H}), 7.73(\mathrm{~d}, J=8.3 \mathrm{~Hz}, 1 \mathrm{H}), 7.56-7.48(\mathrm{~m}, 2 \mathrm{H}) .{ }^{13} \mathrm{C}$ NMR $\left(151 \mathrm{MHz}, \mathrm{DMSO}-d_{6}\right):$ 111.08, $112.59,116.86(\mathrm{~d}, J=22.4 \mathrm{~Hz}), 118.35,119.33,119.81,119.99,120.24(\mathrm{~d}, J=3.3 \mathrm{~Hz}), 121.33,130.81(\mathrm{~d}, J=$ $9.5 \mathrm{~Hz}), 133.49,135.65,143.06,143.92,144.38,145.32,164.91$ (d, $J=252.2 \mathrm{~Hz}), 168.98,174.31$. NB! The spectra are somewhat ambiguous and do not exactly fit with literature ${ }^{44}$ which might due to a combination of tautomerism and use of different magnetic field strength. Adding TFA to the NMR sample (3.2 vol\%) gives unambigious spectra: ${ }^{1} \mathrm{H}$ NMR $\left(400 \mathrm{MHz}\right.$, DMSO- $\left.d_{6}\right) \delta 7.50-7.57(\mathrm{~m}, 2 \mathrm{H}), 7.79(\mathrm{~d}, \mathrm{~J}=8.4 \mathrm{~Hz}, 1 \mathrm{H}), 7.96(\mathrm{dd}, \mathrm{J}=$ 8.4, $1.6 \mathrm{~Hz}, 1 \mathrm{H}), 8.27-8.36(\mathrm{~m}, 3 \mathrm{H}), 8.40(\mathrm{~s}, 1 \mathrm{H}), 12.79(\mathrm{~s}, 1 \mathrm{H})$. This fits exactly with the literature spectrum. ${ }^{44}$ ${ }^{13} \mathrm{C}$ NMR $\left(151 \mathrm{MHz}, \mathrm{DMSO}-\mathrm{d}_{6}\right) \delta 175.21,168.12,165.35(\mathrm{~d}, \mathrm{~J}=252.6 \mathrm{~Hz}), 142.93,132.97,131.31,131.18(\mathrm{~d}, \mathrm{~J}=$ 9.6 Hz), 124.95, 124.13, $120.24(\mathrm{~d}, J=3.1 \mathrm{~Hz}), 117.18(\mathrm{~d}, J=22.6 \mathrm{~Hz}), 115.99,113.93$. A correct number of nonequivalent carbons are found.

6-Phenyl-8H-benzo[g]quinazolino[4,3-b]quinazolin-8-one (17). The compound was synthesized according to previously described general procedure. ${ }^{88}$ A solution of $\mathbf{5 2}(0.77 \mathrm{~g}, 1.97 \mathrm{mmol})$ in acetic anhydride $(30 \mathrm{~mL})$ was stirred at reflux for $1 \mathrm{~h}$, until TLC (DCM:MeOH 5:1, $\mathrm{R}_{\mathrm{f}} 1.00$ ) showed complete reaction. The reaction mixture was then cooled to RT before the suspension was filtered and the solid dried to furnish $\mathbf{1 7}$ as a yellow solid (0.60 g, $1.61 \mathrm{mmol}, 82 \%)$. LC-MS: MS (ESI) m/z $374.2[\mathrm{M}+1]^{+}, \mathrm{t}_{\mathrm{R}}=4.37 \mathrm{~min} .{ }^{1} \mathrm{H}$ NMR (400 MHz, DMSO-d 6 ) $\delta 8.86$ (s, 1H), $8.72(\mathrm{dd}, \mathrm{J}=8.0,1.5 \mathrm{~Hz}, 1 \mathrm{H}), 8.42(\mathrm{~s}, 1 \mathrm{H}), 8.25(\mathrm{~d}, \mathrm{~J}=8.3 \mathrm{~Hz}, 1 \mathrm{H}), 8.20(\mathrm{~d}, \mathrm{~J}=8.5 \mathrm{~Hz}, 1 \mathrm{H}), 7.92-7.85(\mathrm{~m}$, 1H), 7.83-7.78 (m, 1H), 7.77-7.69 (m, 2H), 7.69-7.60 (m, 3H), 7.53-7.44 (m, 3H). ${ }^{13} \mathrm{C}$ NMR (151 MHz, DMSO-d $)$ $\delta 161.14,150.57,145.87,142.58,142.29,137.75,137.20,134.18,131.06,129.91,129.61,129.56,129.15$, $128.98,128.27,128.25,128.03,127.81,126.82,126.07,124.40,121.84,120.57$.

2-((1,2,3,4-Tetrahydroisoquinolin-1-yl)methyl)isoindoline-1,3-dione (23). The compound was synthesized in two steps. For step 1, a previously described procedure ${ }^{55}$ was employed with no deviations. Starting from 2- 
(1,3-dioxoisoindolin-2-yl)acetic acid (4.00 g, 19.5 mmol), 2-((3,4-dihydroisoquinolin-1-yl)methyl)isoindoline-1,3dione (23-I1) was obtained as a light yellow solid (2.6 g, $9.0 \mathrm{mmol}, 46 \%$ ). LC-MS: MS (ESI) m/z $291.3[\mathrm{M}+1]^{+}, \mathrm{t}_{\mathrm{R}}$ $=1.74 \mathrm{~min}$. For step 2 , a previously described procedure ${ }^{55}$ was employed with minor deviations. To a solution of 23-I1 $(0.76 \mathrm{~g}, 2.6 \mathrm{mmol})$ in $\mathrm{MeOH}(8 \mathrm{~mL})$ was added $4 \mathrm{M} \mathrm{HCl}$ in 1,4-dioxane $(0.8 \mathrm{~mL})$, and the mixture was stirred at RT for 30 min. The solvents were evaporated in vacuo, the solid obtained was re-dissolved in $\mathrm{MeOH}$ $(5 \mathrm{~mL})$ and treated with $\mathrm{NaBH}_{3} \mathrm{CN}(330.7 \mathrm{mg}, 5.3 \mathrm{mmol})$. The reaction mixture was stirred at $\mathrm{RT}$ for $30 \mathrm{~min}$. The mixture was then concentrated in vacuo and extracted with EtOAc $(2 \times 2.5 \mathrm{~mL})$. The organic layers were combined, washed with $\mathrm{NaHCO}_{3}$ (aq.), dried over $\mathrm{Na}_{2} \mathrm{SO}_{4}$, and the solvent removed in vacuo. The crude was purified by flash chromatography (heptane:EtOAc, $0-100 \%$ gradient) to furnish 23 as a white crystalline solid $(0.58 \mathrm{~g}$, $2.0 \mathrm{mmol}, 76 \%)$. LC-MS: MS (ESI) m/z $293.2[\mathrm{M}+1]^{+}, \mathrm{t}_{\mathrm{R}}=1.54 \mathrm{~min}$.

(1S,2R)-2-(1-((1,3-Dioxoisoindolin-2-yl)methyl)-1,2,3,4-tetrahydroisoquinoline-2-carbonyl)cyclohexane1-carboxylic acid (24). The compound was synthesized according to previously described procedure with no deviations. ${ }^{55}$ Starting from 23 (0.041 g, $\left.0.14 \mathrm{mmol}\right), 24$ was obtained as a white solid (yield ND). LC-MS: MS (ESI) $\mathrm{m} / \mathrm{z} 447.3[\mathrm{M}+1]^{+}, \mathrm{t}_{\mathrm{R}}=3.34 \mathrm{~min}$.

4-nitronaphthalen-1-amine (29). The compound was synthesized according to previously described procedure $^{22}$ with no deviations. Starting from 1-nitronaphthalene $(6.0 \mathrm{~g}, 34.6 \mathrm{mmol}), 29$ was obtained as a goldenyellow crystalline solid (3.59 g, $19.1 \mathrm{mmol}, 55 \%)$. LC-MS: MS (ESI) m/z $189.1[\mathrm{M}+1]^{+}, \mathrm{t}_{\mathrm{R}}=2.87 \mathrm{~min} .{ }^{1} \mathrm{H}$ NMR (DMSO- $\left.d_{6}\right) \delta 8.90(\mathrm{~d}, J=8.8 \mathrm{~Hz}, 1 \mathrm{H}), 8.39(\mathrm{dd}, J=9.0,1.9 \mathrm{~Hz}, 1 \mathrm{H}), 8.30(\mathrm{~d}, J=8.5 \mathrm{~Hz}, 1 \mathrm{H}$ ), 7.74 (ddd, $J=6.8,5.1$, $3.5 \mathrm{~Hz}, 1 \mathrm{H}), 7.61-7.49(\mathrm{~m}, 3 \mathrm{H}), 6.68(\mathrm{dd}, J=8.9,1.9 \mathrm{~Hz}, 1 \mathrm{H}) .{ }^{13} \mathrm{C}$ NMR (DMSO-d $)_{6} \delta 153.64,131.64,130.37$, $130.34,127.90,124.93,123.52,123.35,120.59,105.29$.

Naphthalene-1,4-diamine (30). The compound was synthesized according to previously described procedure ${ }^{56}$ with minor deviations. To a solution of 29 (1.37 g, $\left.7.14 \mathrm{mmol}\right)$ in abs. EtOH (50 mL) was added $5 \mathrm{w} / \mathrm{w} \%$ $\mathrm{Pd} / \mathrm{C}(0.14 \mathrm{~g}, 10 \mathrm{w} / \mathrm{w} \%)$. The flask was subjected to three vacuum-nitrogen cycles and then put under hydrogen atmosphere ( $1 \mathrm{~atm}$, balloon). The reaction mixture was stirred under hydrogen for $2 \mathrm{~h}$, until TLC (heptane:EtOAc 1:1, $\left.R_{f} 0.17\right)$ showed complete conversion. The reaction mixture was then filtrated through a bed of 
celite, and the filtrate concentrated in vacuo to furnish $\mathbf{3 0}$ as a green-brown crystalline solid. No further purification or characterization was performed, and the next step carried out immediately after due to the rapid degradation of the diamine.

1-bromo-4-nitronaphthalene (31). The compound was synthesized according to previously described general procedure ${ }^{89}$ with minor deviations. To a solution of 29 ( $0.47 \mathrm{~g}, 2.5 \mathrm{mmol}, 1.0$ equiv) in $\mathrm{MeCN}$ ( $30 \mathrm{~mL}$ ) were added $\mathrm{CuBr}_{2}$ (10 mg, $0.045 \mathrm{mmol}, 0.02$ equiv), camphorsulfonic acid (0.70 g, $3.0 \mathrm{mmol}, 1.2$ equiv), $t$-BuONO (0.36 mL, $3.0 \mathrm{mmol}, 1.2$ equiv), and TBAB (1.61 g, $5.0 \mathrm{mmol}, 2.0$ equiv). The reaction mixture was stirred at 60 ${ }^{\circ} \mathrm{C}$ for $24 \mathrm{~h}$, until TLC (heptane:EtOAc 1:1, $\mathrm{R}_{\mathrm{f}}$ 0.82) showed complete reaction. The reaction mixture was then concentrated in vacuo, the residue re-dissolved in DCM $(40 \mathrm{~mL})$, the solution washed with water $(40 \mathrm{~mL})$ and sat. brine $(40 \mathrm{~mL})$, dried over $\mathrm{Na}_{2} \mathrm{SO}_{4}$ and concentrated to dryness in vacuo. The crude was purified by flash chromatography (heptane:EtOAc, 0-100\% gradient) to furnish 31 as a red-brown solid (0.52 g, $2.1 \mathrm{mmol}, 83 \%)$. ${ }^{1} \mathrm{H}$ NMR (400 MHz DMSO- $d_{6}$ ) $\delta 8.38$ (dddd, $\left.J=11.3,5.8,3.2,1.9 \mathrm{~Hz}, 2 \mathrm{H}\right), 8.22(\mathrm{~d}, J=8.2 \mathrm{~Hz}, 1 \mathrm{H}), 8.13(\mathrm{~d}, J=8.2$ $\mathrm{Hz}, 1 \mathrm{H}), 7.95-7.86(\mathrm{~m}, 2 \mathrm{H}) .{ }^{13} \mathrm{C}$ NMR $\left(101 \mathrm{MHz}, \mathrm{DMSO}-d_{6}\right) \delta 131.63,130.44,129.44,129.20,128.55,127.46$, $125.00,124.17,124.12,123.04$.

(S)-1-(4-nitronaphthalen-1-yl)pyrrolidine-3-carboxylic acid (32). The compound was synthesized according to previously described procedure ${ }^{36}$ with minor deviations. To a pressure vial were added $31(0.10 \mathrm{~g}, 0.40$ mmol, 1.0 equiv), $\mathrm{K}_{2} \mathrm{CO}_{3}(0.16 \mathrm{~g}, 1.19 \mathrm{mmol}, 3.0$ equiv), (S)-pyrrolidine-3-carboxylic acid (0.090 g, $0.80 \mathrm{mmol}$, 2.0 equiv), Cul (8 $\mathrm{mg}, 0.040 \mathrm{mmol}, 0.1$ equiv), and dry DMF ( $2.5 \mathrm{~mL})$. The vial was capped, subjected to three vacuum-argon cycles, and the reaction mixture stirred at $150{ }^{\circ} \mathrm{C}$ for $24 \mathrm{~h}$, until LC-MS showed complete reaction. The reaction mixture was then cooled to $\mathrm{RT}$, followed by addition of $1 \mathrm{M} \mathrm{HCl}(10 \mathrm{~mL})$, extraction with $\mathrm{DCM}$ $(3 \times 15 \mathrm{~mL})$, and the combined organic phases washed with sat. brine $(10 \mathrm{~mL})$, dried over $\mathrm{Na}_{2} \mathrm{SO}_{4}$, filtered, and concentrated to dryness in vacuo to furnish 32 as a yellow oil $(0.11 \mathrm{~g}, 0.38 \mathrm{mmol}, 96 \%)$. LC-MS: MS (ESI) m/z $285.0[\mathrm{M}-1]^{\prime}, 571.1[2 \mathrm{M}-1]^{-}, \mathrm{t}_{\mathrm{R}}=3.63 \mathrm{~min}$.

(S)-1-(4-aminonaphthalen-1-yl)pyrrolidine-3-carboxylic acid (33). The compound was synthesized according to previously described procedure ${ }^{36}$ with some deviations. A solution of $32(0.11 \mathrm{~g}, 0.38 \mathrm{mmol})$ in 
$\mathrm{MeOH} /$ EtOAc ( $8 \mathrm{~mL}, 5: 2$ ) was subjected to hydrogenation using an $\mathrm{H}$-Cube Mini Plus ${ }^{\mathrm{TM}}$ apparatus with a $10 \%$ $\mathrm{Pd} / \mathrm{C}$ catalyst cartridge, pressure set at 2 bar, temperature set to $\mathrm{RT}$, and flow rate set to $1.0 \mathrm{~mL} / \mathrm{min}$. LC-MS showed complete conversion in the output solution, which was then concentrated to dryness in vacuo to furnish 33 as a yellow oil. LC-MS: MS (ESI) m/z 255.0 [M-1]', $t_{R}=1.75$ min. No further purification or characterization was performed, and the next step carried out immediately after due to the rapid degradation of the diamine.

$N, N^{\prime}$-(naphthalene-1,4-diyl)bis(4-ethoxybenzenesulfonamide) (34). The compound was synthesized according to previously described procedure ${ }^{56}$ with minor deviations. To a solution of 30 (0.32 g, $2.02 \mathrm{mmol}, 1.0$ equiv prepared freshly) in $\mathrm{DCM}(5.0 \mathrm{~mL})$ was added pyridine $(1.07 \mathrm{~mL}, 13.22 \mathrm{mmol}, 6.5$ equiv) followed by 4 ethoxybenzenesulfonyl chloride $(1.00 \mathrm{~g}, 4.53 \mathrm{mmol}, 2.2$ equiv). The reaction mixture was stirred at RT for 10 min, until TLC (heptane:EtOAc 1:1, $R_{f} 0.30$ ) showed complete reaction. The reaction mixture was then acidified with $2 \mathrm{M} \mathrm{HCl}(10 \mathrm{~mL})$, extracted with $\mathrm{DCM}(2 \times 10 \mathrm{~mL})$, the combined organic phases washed with sat. brine $\left(2 \times 15 \mathrm{~mL}\right.$ ), dried over $\mathrm{Na}_{2} \mathrm{SO}_{4}$, and concentrated to dryness in vacuo. The crude was purified by flash chromatography (heptane:EtOAc, $0-70 \%$ gradient) to furnish 34 as a pink solid $(0.51 \mathrm{~g}, 0.97 \mathrm{mmol}, 48 \%) .{ }^{1} \mathrm{H}$ NMR (DMSO- $\left.d_{6}\right) \delta 10.00(s, 2 H), 8.01-7.90(m, 2 H), 7.61-7.48(m, 4 H), 7.39(d t, J=6.5,3.1 \mathrm{~Hz}, 2 \mathrm{H}), 7.01(\mathrm{~s}, 2 \mathrm{H})$, 6.98-6.91 (m, 4H), $4.04(q, J=7.0 \mathrm{~Hz}, 4 \mathrm{H}), 1.30(\mathrm{t}, \mathrm{J}=7.0 \mathrm{~Hz}, 6 \mathrm{H}) .{ }^{13} \mathrm{C}$ NMR (DMSO-d $)$ ) $\delta$ 161.58, 131.21, 131.05, $130.03,128.86,126.03,123.33,122.71,114.52,63.64,14.35$.

$N, N^{\prime}-((1 Z, 4 Z)$-naphthalene-1,4-diylidene)bis(4-ethoxybenzenesulfonamide) (35). The compound was synthesized according to previously described procedure ${ }^{56}$ with no deviations. Starting from 34 (0.10 g, $0.19 \mathrm{mmol}), 35$ was obtained as a red-brown solid $(0.089 \mathrm{~g}, 0.17 \mathrm{mmol}, 89 \%) .{ }^{1} \mathrm{H}$ NMR (Chloroform-d) $\delta 8.34(\mathrm{~s}$, 2H), 8.24-8.13 (m, 2H), 8.07-7.91 (m, 4H), 7.66-7.54 (m, 2H), 7.08-6.97 (m, 4H), 4.13 (q, J = 7.0 Hz, 4H), $1.46(t$, $J=7.0 \mathrm{~Hz}, 6 \mathrm{H}$ ). ${ }^{13} \mathrm{C}$ NMR (Chloroform- $d$ ) $\delta 163.16,161.37,133.27,132.88,132.00,130.60,129.90,126.95$, $114.88,64.25,14.76$.

Benzyl 3-oxocyclohexane-1-carboxylate (37). The compound was synthesized in three steps using previously described procedures ${ }^{39,} 90$ with some deviations. For step 1, a flask was purged with argon and then cy- 
clohex-2-en-1-one $\left(2.3 \mathrm{~mL}, 24.0 \mathrm{mmol}, 1.0\right.$ equiv), 1,4-dioxane $(25 \mathrm{~mL})$, and $\mathrm{Cs}_{2} \mathrm{CO}_{3}(0.039 \mathrm{~g}, 0.12 \mathrm{mmol}$, 0.005 equiv) were added. The flask was charged with a condenser and the system sealed and purged with argon. Under argon was then added trimethylsilyl cyanide $(4.6 \mathrm{~mL}, 36.0 \mathrm{mmol}, 1.5$ equiv) and water $(1.7 \mathrm{~mL}$, $96.0 \mathrm{mmol}, 4.0$ equiv). The reaction mixture was stirred at $100{ }^{\circ} \mathrm{C}$ for $2 \mathrm{~h}$, until TLC (heptane:EtOAc $1: 1, R_{f} 0.31$ ) showed complete reaction. The reaction mixture was then cooled to RT, followed by addition of excess water (25 mL. OBS! Formation of toxic HCN gas), extraction with EtOAc $(5 \times 50 \mathrm{~mL})$. The combined organic phases were washed with sat. brine $(50 \mathrm{~mL})$, dried over $\mathrm{Na}_{2} \mathrm{SO}_{4}$, filtered, and concentrated to dryness in vacuo. The crude was purified by flash chromatography (heptane:EtOAc, 40-55\% gradient) to furnish 3-oxocyclohexane-1carbonitrile (37-I1) as a slightly yellow oil $(2.42 \mathrm{~g}, 19.6 \mathrm{mmol}, 82 \%) .{ }^{1} \mathrm{H} \mathrm{NMR}\left(600 \mathrm{MHz}, \mathrm{DMSO}-d_{6}\right) \delta 3.38$ (tdd, $J$ $=8.3,5.2,3.9 \mathrm{~Hz}, 1 \mathrm{H}), 2.62(\mathrm{dd}, J=14.5,5.3 \mathrm{~Hz}, 1 \mathrm{H}), 2.54(\mathrm{dd}, J=14.5,8.3 \mathrm{~Hz}, 1 \mathrm{H}), 2.31(\mathrm{t}, J=6.7 \mathrm{~Hz}, 2 \mathrm{H}), 2.03$ (ddt, $J=12.1,8.0,4.0 \mathrm{~Hz}, 1 \mathrm{H}), 1.96-1.85(\mathrm{~m}, 2 \mathrm{H}), 1.85-1.76(\mathrm{~m}, 1 \mathrm{H}) .{ }^{13} \mathrm{C}$ NMR $\left(151 \mathrm{MHz}, \mathrm{DMSO}-d_{6}\right) \delta 206.65$, $121.48,42.50,40.13,27.71,26.86,23.16$. For step 2 , a solution of the $\mathbf{3 7 - I}$ ( $2.42 \mathrm{~g}, 19.6 \mathrm{mmol}, 1.0$ equiv) in $12 \mathrm{M} \mathrm{HCl}\left(50.0 \mathrm{~mL}, 600.0 \mathrm{mmol}, 30.6\right.$ equiv) was stirred at $80^{\circ} \mathrm{C}$ for $45 \mathrm{~min}$, until TLC (heptane:EtOAc:AcOH 1:1:0.1, $R_{f} 0.21$ ) showed complete reaction. The reaction mixture was then diluted with water (50 $\mathrm{mL}$ ), extracted with EtOAc $(5 \times 100 \mathrm{~mL})$, and the combined organic phases dried over $\mathrm{Na}_{2} \mathrm{SO}_{4}$, filtered, and concentrated to dryness in vacuo. The crude was purified by reverse-phase column chromatography using a C18 column on the CombiFlash (buffer $\mathrm{A} \mathrm{H}_{2} \mathrm{O}: \mathrm{MeCN}$ :TFA 95:5:0.1, buffer $\mathrm{B} \mathrm{H}_{2} \mathrm{O}$ :MeCN:TFA 5:95:0.1, 0-10\% gradient) to furnish 3oxocyclohexane-1-carboxylic acid (37-12) as a white solid (1.24 g, 8.72 mmol, 44\%). LC-MS: MS (ESI) m/z 141.1 [M-1]', $283.1[2 \mathrm{M}-1]^{-}, \mathrm{t}_{\mathrm{R}}=1.57 \mathrm{~min} .{ }^{1} \mathrm{H}$ NMR $\left(600 \mathrm{MHz}, \mathrm{DMSO}-d_{6}\right) \delta 3.68(\mathrm{~s}, 1 \mathrm{H}), 2.77$ (tq, $J=9.4,4.9,4.4 \mathrm{~Hz}$, 1H), 2.44 (ddd, $J=14.6,9.7,1.3 \mathrm{~Hz}, 1 \mathrm{H}), 2.35$ (ddt, $J=14.6,5.1,1.5 \mathrm{~Hz}, 1 \mathrm{H}$ ), 2.29 (dddd, $J=15.8,10.1,5.8$, $1.3 \mathrm{~Hz}, 1 \mathrm{H}), 2.24-2.16(\mathrm{~m}, 1 \mathrm{H}), 2.03-1.93(\mathrm{~m}, 1 \mathrm{H}), 1.91-1.82(\mathrm{~m}, 1 \mathrm{H}), 1.80-1.62(\mathrm{~m}, 2 \mathrm{H}) .{ }^{13} \mathrm{C} \mathrm{NMR}(151 \mathrm{MHz}$, DMSO- $\left.d_{6}\right) \delta 208.89,175.14,42.65,42.09,40.30,26.92,23.58$. For step 3, a solution of 37-12 (1.24 g, $8.72 \mathrm{mmol}$, 1.0 equiv) and benzyl bromide $(1.14 \mathrm{~mL}, 9.59 \mathrm{mmol}, 1.1$ equiv) in dry MeCN $(16 \mathrm{~mL})$ was added DBU $(1.30 \mathrm{~mL}$, $8.72 \mathrm{mmol}, 1.0$ equiv). The reaction mixture stirred at RT for $1 \mathrm{~h}$, until TLC (heptane:EtOAc:AcOH 1:1:0.1, $\mathrm{R}_{\mathrm{f}}$ 0.59) showed complete reaction. The reaction mixture was then concentrated in vacuo, the residue re- 
dissolved in EtOAc $(50 \mathrm{~mL})$ and the solution washed with sat. $\mathrm{NaHCO}_{3}(30 \mathrm{~mL}), 1 \mathrm{M} \mathrm{HCl}(30 \mathrm{~mL})$, and sat. brine $(30 \mathrm{~mL})$. The organic phase was dried over $\mathrm{Na}_{2} \mathrm{SO}_{4}$, filtered, and concentrated to dryness in vacuo. The crude was purified by flash chromatography (heptane:EtOAc, 20-40\% gradient) to furnish 37 as a colorless oil (1.02 g, $4.39 \mathrm{mmol}, 50 \%)$. LC-MS: MS (ESI) m/z $233.1[\mathrm{M}+1]^{+}, 255.1[\mathrm{M}+\mathrm{Na}]^{+}, \mathrm{t}_{\mathrm{R}}=3.13 \mathrm{~min} .{ }^{1} \mathrm{H} \mathrm{NMR}(400 \mathrm{MHz}, \mathrm{DMSO}-$ d $d_{6} \delta$ 7.50-7.21 (m, 5H), 5.20-5.00 (m, 2H), $2.96(\mathrm{dt}, J=9.4,4.7 \mathrm{~Hz}, 1 \mathrm{H}), 2.52-2.50(\mathrm{~m}, 1 \mathrm{H}), 2.40(\mathrm{dd}, J=14.7$, $5.2 \mathrm{~Hz}, 1 \mathrm{H}), 2.31(\mathrm{ddd}, J=15.2,9.7,5.6 \mathrm{~Hz}, 1 \mathrm{H}), 2.26-2.16(\mathrm{~m}, 1 \mathrm{H}), 2.00(\mathrm{dt}, J=13.2,4.2 \mathrm{~Hz}, 1 \mathrm{H}), 1.91-1.75(\mathrm{~m}$, 2H), 1.76-1.60 (m, 1H). ${ }^{13} \mathrm{C}$ NMR (101 MHz, DMSO- $\left.d_{6}\right) \delta 208.43,173.32,136.07,128.42,127.99,127.77,65.70$, $42.38,41.93,40.21,26.83,23.38$.

Benzyl 3-(((trifluoromethyl)sulfonyl)oxy)cyclohex-2-ene-1-carboxylate (38). The compound was synthesized according the previously described procedure ${ }^{39}$ with some deviations. To a dry round-bottomed flask was added 37 (1.56 g, $6.72 \mathrm{mmol}, 1.0$ equiv), Tf $2 \mathrm{NPh}$ (3.12 g, $8.74 \mathrm{mmol}, 1.30$ equiv), and dry degassed THF (70 mL). Under argon and at $-78{ }^{\circ} \mathrm{C}$ was added dropwise over $10 \mathrm{~min}$ a freshly prepared solution of LiHMDS (20.0 mL $0.44 \mathrm{M}$ solution in hexane, $8.74 \mathrm{mmol}, 1.30$ equiv). The reaction mixture was stirred and allowed to warm to RT in the dry-ice bath over $16 \mathrm{~h}$, until TLC (heptane:EtOAc 1:1, $\mathrm{R}_{\mathrm{f}} 0.75$ ) showed complete reaction. The reaction mixture was then quenched with water $(10 \mathrm{~mL})$ and concentrated in vacuo. The residue was re-dissolved in DCM $(25 \mathrm{~mL})$, washed with water $(20 \mathrm{~mL})$, sat. $\mathrm{NaHCO}_{3}(2 \times 20 \mathrm{~mL})$, sat. brine $(20 \mathrm{~mL})$, and the organic phase dried over $\mathrm{Na}_{2} \mathrm{SO}_{4}$, filtered, and concentrated to dryness in vacuo to yield $\mathbf{3 8}$ as a yellowish crystalline solid (2.44 g, $6.70 \mathrm{mmol}$, quantitative). No further purification or characterization were performed.

Ethyl 1-(3-bromophenyl)-5-cyclopropyl-1H-pyrazole-4-carboxylate (40). The compound was synthesized according to previously described procedure ${ }^{39}$ with no deviations. Starting from ethyl 3-cyclopropyl-3oxopropanoate (1.47 mL, $10.0 \mathrm{mmol}, 1.0$ equiv), DMF-dimethyl acetal (1.46 mL, $11.0 \mathrm{mmol}, 1.1$ equiv), and 3bromophenylhydrazine $\cdot \mathrm{HCl}(2.24 \mathrm{~g}, 10.0 \mathrm{mmol}), 40$ was obtained as a dark red oil $(3.35 \mathrm{~g}, 10.0 \mathrm{mmol}$, quantitative). ${ }^{1} \mathrm{H}$ NMR (400 MHz, Chloroform- $d$ ) $\delta 8.00(s, 1 \mathrm{H}), 7.73(\mathrm{t}, J=2.0 \mathrm{~Hz}, 1 \mathrm{H}), 7.55$ (ddd, J = 8.0, 1.9, $1.1 \mathrm{~Hz}, 1 \mathrm{H}$ ), $7.49(\mathrm{ddd}, J=8.0,2.0,1.0 \mathrm{~Hz}, 1 \mathrm{H}), 7.35(\mathrm{t}, J=8.0 \mathrm{~Hz}, 1 \mathrm{H}), 4.32(\mathrm{q}, J=7.1 \mathrm{~Hz}, 2 \mathrm{H}), 2.00-1.90(\mathrm{~m}, 1 \mathrm{H}), 1.37(\mathrm{t}, J=$ 
$7.1 \mathrm{~Hz}, 3 \mathrm{H}), 1.02-0.92(\mathrm{~m}, 2 \mathrm{H}), 0.68-0.54(\mathrm{~m}, 2 \mathrm{H}) .{ }^{13} \mathrm{C}$ NMR (101 MHz, Chloroform-d) $\delta 163.13,147.52,142.71$, $140.71,131.43,130.22,128.55,124.00,122.47,114.79,77.36,60.25,14.55,8.80,7.43$.

\section{Ethyl 5-cyclopropyl-1-(3-(4,4,5,5-tetramethyl-1,3,2-dioxaborolan-2-yl)phenyl)-1H-pyrazole-4-carboxylate}

(41). The compound was synthesized according to previously described procedure ${ }^{39}$ with minor deviations. To a solution of 40 (3.35 g, $10.0 \mathrm{mmol}, 1.0$ equiv) in dry degassed 1,4-dioxane $(50 \mathrm{~mL})$ were added $\mathrm{B}_{2} \mathrm{pin}_{2}(2.79 \mathrm{~g}$, $11.0 \mathrm{mmol}, 1.1$ equiv), KOAc (1.96 g, $20.0 \mathrm{mmol}, 2.0$ equiv), and $\mathrm{Pd}(\mathrm{dppf}) \mathrm{Cl}_{2}(0.37 \mathrm{~g}, 0.50 \mathrm{mmol}, 0.05$ equiv). The reaction mixture was stirred under reflux for $4 \mathrm{~h}$, until LC-MS showed complete reaction. The reaction mixture was then concentrated in vacuo, the residue re-dissolved in EtOAc $(50 \mathrm{~mL})$ and the solution washed with water $(2 \times 40 \mathrm{~mL})$ and sat. brine $(40 \mathrm{~mL})$, dried over $\mathrm{Na}_{2} \mathrm{SO}_{4}$, filtered, and concentrated to dryness in vacuo. The crude was purified by flash chromatography (heptane:EtOAc, $20-45 \%$ gradient) to furnish $\mathbf{4 1}$ as a dark green oil (2.90 g, $7.6 \mathrm{mmol}, 76 \%) .{ }^{1} \mathrm{H}$ NMR $\left(400 \mathrm{MHz}, \mathrm{DMSO}-\mathrm{d}_{6}\right) \delta 7.98(\mathrm{~s}, 1 \mathrm{H}), 7.82-7.73(\mathrm{~m}, 3 \mathrm{H}), 7.56(\mathrm{td}, J=7.4,1.2 \mathrm{~Hz}$, 1H), $4.25(\mathrm{q}, J=7.1 \mathrm{~Hz}, 2 \mathrm{H}), 2.08(\mathrm{tt}, J=8.6,5.5 \mathrm{~Hz}, 1 \mathrm{H}), 1.31(\mathrm{~s}, 12 \mathrm{H}), 0.92-0.77(\mathrm{~m}, 3 \mathrm{H}), 0.53-0.40(\mathrm{~m}, 2 \mathrm{H}) .{ }^{13} \mathrm{C}$ NMR on crude (151 MHz, Chloroform-d) $\delta 163.47,147.66,142.67,142.07,135.66,129.22,125.74,124.77$, $124.71,114.77,84.44,60.68,60.32,25.22,14.74,14.41,8.94,8.75,7.73$.

Ethyl 1-(5'-((benzyloxy)carbonyl)-2',3',4',5'-tetrahydro-[1,1'-biphenyl]-3-yl)-5-cyclopropyl-1H-pyrazole-4carboxylate (42). This previously unreported compound was synthesized according to previously described procedure ${ }^{39}$ with some deviations. A $50 \mathrm{~mL}$ two-necked flask charged with a condenser was purged with argon and then added to a solution of 38 (1.71 g, $4.47 \mathrm{mmol}, 1.0$ equiv), 41 (2.44 g, $6.70 \mathrm{mmol}, 1.50$ equiv), $\mathrm{Na}_{2} \mathrm{CO}_{3}$ (4.47 mL $3 \mathrm{M}$ aq. solution, $13.4 \mathrm{mmol}, 3.0$ equiv), and $\mathrm{Pd}\left(\mathrm{PPh}_{3}\right)_{4}(0.39 \mathrm{~g}, 0.33 \mathrm{mmol}, 0.075$ equiv) in toluene/abs. EtOH (26 mL, 10:3). The system was subjected to three vacuum-argon cycles again, and the reaction mixture then stirred at reflux under argon (balloon) for $3 \mathrm{~h}$, until LC-MS showed complete reaction. The reaction mixture was then diluted with EtOAc $(70 \mathrm{~mL})$, washed with water $(1 \times 40 \mathrm{~mL}$ and $1 \times 20 \mathrm{~mL})$, and sat. brine $(20 \mathrm{~mL})$, dried over $\mathrm{Na}_{2} \mathrm{SO}_{4}$, filtered, and concentrated to dryness in vacuo. The crude was purified by flash chromatography (heptane:EtOAc, 10-30\% gradient) to furnish 42 as a greenish oil (1.44 g, 3.06 mmol, 69\%). LCMS: MS (ESI) m/z $471.3[M+1]^{+}, t_{R}=4.34 \mathrm{~min}$. 
(cis)-3-(3-(5-cyclopropyl-4-(ethoxycarbonyl)-1H-pyrazol-1-yl)phenyl)cyclohexane-1-carboxylic acid (43).

This previously unreported compound was synthesized according the previously described procedure ${ }^{39}$ with some deviations. To a solution of $42(1.44 \mathrm{~g}, 3.06 \mathrm{mmol})$ in dry degassed EtOH $(75 \mathrm{~mL})$ was added 5\% Pd/C $(0.16 \mathrm{~g}, 11 \mathrm{w} / \mathrm{w} \%)$. The flask was sealed and subjected to three vacuum-nitrogen cycles before hydrogen was introduced with a balloon. The reaction mixture was stirred under hydrogen ( 1 atm, balloon) at RT for 24 h, until TLC (heptane:EtOAc:AcOH 1:1:0.1, $R_{f}$ 0.22) showed complete reaction. The reaction mixture was then filtered through a bed of celite and the filtrate concentrated to dryness in vacuo to furnish $\mathbf{4 3}$ as a slightly yellow sticky solid (1.17 g, $3.06 \mathrm{mmol}$, quantitative). LC-MS: MS (ESI) m/z $383.3[\mathrm{M}+1]^{+}, \mathrm{t}_{\mathrm{R}}=3.51 \mathrm{~min} .{ }^{1} \mathrm{H} \mathrm{NMR}$ $\left(400 \mathrm{MHz}, \mathrm{DMSO}-d_{6}\right) \delta 7.96(\mathrm{~s}, 1 \mathrm{H}), 7.52-7.27(\mathrm{~m}, 4 \mathrm{H}), 4.24(\mathrm{q}, J=7.1 \mathrm{~Hz}, 2 \mathrm{H}), 2.86-2.60(\mathrm{~m}, 1 \mathrm{H}), 2.38(\mathrm{tt}, J=$ 11.8, 3.3 Hz, 1H), $2.12(\mathrm{tt}, J=8.6,5.4 \mathrm{~Hz}, 1 \mathrm{H}), 2.02(\mathrm{~d}, J=12.4 \mathrm{~Hz}, 1 \mathrm{H}), 1.93(\mathrm{~d}, J=12.6 \mathrm{~Hz}, 1 \mathrm{H}), 1.84(\mathrm{dt}, J=$ 16.2, $5.7 \mathrm{~Hz}, 2 \mathrm{H}), 1.45(\mathrm{ddt}, J=34.8,26.3,13.2 \mathrm{~Hz}, 4 \mathrm{H}), 1.30(\mathrm{t}, J=7.1 \mathrm{~Hz}, 3 \mathrm{H}), 0.93-0.71(\mathrm{~m}, 2 \mathrm{H}), 0.58-0.34(\mathrm{~m}$, 2H). ${ }^{13} \mathrm{C}$ NMR $(101 \mathrm{MHz}$, DMSO-d 6 ) $\delta 176.35,162.33,147.78,146.95,141.42,139.18,128.90,126.77,123.64$, $122.90,113.50,59.54,42.73,42.41,36.00,32.80,28.15,25.32,14.27,8.16,8.11,7.03$. ROESY $(400 \mathrm{MHz}$, DMSO- $\left.d_{6}\right)$ : The observation of a cross-peak between $\mathrm{H} 15$ and $\mathrm{H} 19$, suggests a 1,3-diaxial relationship and thus a cis-configuration of the cyclohexane ring (Supporting Information Figure S1).

5-((2,4-Dimethylphenyl)thio)-1,3-dimethylpyrimidine-2,4(1H,3H)-dione (45). This previously unreported compound was synthesized according to a previously described general procedure ${ }^{59}$ with minor deviations. To a solution of $\mathrm{NaOH}(0.80 \mathrm{~g}, 20.0 \mathrm{mmol}, 1.0$ equiv) in $\mathrm{MeOH}(20 \mathrm{~mL})$ was added 2,4-dimethylbenzenethiol ( $2.71 \mathrm{~mL}, 20.0 \mathrm{mmol}, 1.0$ equiv). The reaction mixture was stirred at $80^{\circ} \mathrm{C}$ for $1 \mathrm{~h}$, after which the mixture was concentrated to dryness in vacuo to furnish the sodium thiolate (OBS! The thiol/thiolate is very foul-smelling). To a solution of 5-bromo-1,3-dimethyluracil $(1.10 \mathrm{~g}, 5.0 \mathrm{mmol}, 1.0$ equiv) in NMP (15 mL) was added sodium 2,4-dimethylbenzenethiolate ( $1.60 \mathrm{~g}, 10.0 \mathrm{mmol}, 2.0$ equiv, prepared above). The reaction mixture was stirred under microwave irradiation at $130{ }^{\circ} \mathrm{C}$ for $10 \mathrm{~min}$, until TLC (heptane:EtOAc $1: 1, \mathrm{R}_{\mathrm{f}} 0.40$ ) showed complete reaction. The reaction mixture was then acidified with $2 \mathrm{M} \mathrm{HCl}(15 \mathrm{~mL})$ and extracted with $\mathrm{DCM}(2 \times 20 \mathrm{~mL})$. The combined organic phases were washed with sat. brine $(20 \mathrm{~mL})$, dried over $\mathrm{Na}_{2} \mathrm{SO}_{4}$, filtered, and concentrated to 
dryness in vacuo. Water $(20 \mathrm{~mL})$ was then added to precipitate out the crude product, which was isolated by filtration. The crude was purified by purified by flash chromatography (heptane:EtOAc, $0-50 \%$ ) to furnish $\mathbf{4 5}$ as a slightly yellow solid (0.86 g, $3.11 \mathrm{mmol}, 62 \%)$. LC-MS: MS (ESI) m/z $277.2[\mathrm{M}+1]^{+}, \mathrm{t}_{\mathrm{R}}=3.13 \mathrm{~min}$.

5-((2,4-Dimethylphenyl)sulfonyl)-1,3-dimethylpyrimidine-2,4(1H,3H)-dione (46). This previously unreported compound was synthesized according to a previously described general procedure ${ }^{91}$ with some deviations. To a solution of $45\left(0.86 \mathrm{~g}, 3.11 \mathrm{mmol}, 1.00\right.$ equiv) in $\mathrm{DCM}(30 \mathrm{~mL})$ at $0{ }^{\circ} \mathrm{C}$ was added dropwise a solution of mCPBA (1.61 g, $9.33 \mathrm{mmol}, 3.00$ equiv) in DCM (15 mL). The reaction mixture was allowed to slowly reach RT over $3 \mathrm{~h}$ under stirring, until TLC (heptane:EtOAc 1:1, $\mathrm{R}_{\mathrm{f}} 0.27$ ) showed complete reaction. The reaction mixture was then quenched by addition of sat. aq. $\mathrm{NaHCO}_{3}(50 \mathrm{~mL})$, and the organic phase washed with sat. aq. $\mathrm{NaHCO}_{3}$ $(50 \mathrm{~mL})$ and $1 \mathrm{M} \mathrm{NaOH}(50 \mathrm{~mL})$ and then dried over $\mathrm{Na}_{2} \mathrm{SO}_{4}$, filtered, and concentrated to dryness in vacuo to furnish 46 as a white crystalline solid $(0.68 \mathrm{~g}, 2.21 \mathrm{mmol}, 71 \%)$. LC-MS: MS (ESI) $\mathrm{m} / \mathrm{z} 309.5[M+1]^{+}, t_{R}=$ $1.99 \mathrm{~min}$.

5-((2,4-Dimethylphenyl)sulfonyl)-2-thioxo-2,3-dihydropyrimidin-4(1H)-one (47). The compound was synthesized according to a previously described general procedure ${ }^{60}$ with some deviations. In a pressure vial charged with a freshly prepared NaOEt solution $(5.0 \mathrm{~mL} 0.6 \mathrm{M}$ solution in EtOH, $3.00 \mathrm{mmol}, 3.0$ equiv) were added 46 ( $0.31 \mathrm{~g}, 1.00 \mathrm{mmol}, 1.0$ equiv) and thiourea $(0.23 \mathrm{~g}, 3.00 \mathrm{mmol}, 1.0$ equiv). The vial was capped, purged with argon, and the reaction mixture stirred at $100{ }^{\circ} \mathrm{C}$ for $16 \mathrm{~h}$, until LC-MS showed complete reaction. The reaction mixture was then added $2 \mathrm{M} \mathrm{HCl}(\sim 5 \mathrm{~mL})$ to precipitate out the crude product, which was isolated by filtration and washed with water $(10 \mathrm{~mL})$ to furnish 47 as a slight yellow crystalline solid $(0.12 \mathrm{~g}, 0.40 \mathrm{mmol}$, 40\%). LC-MS: MS (ESI) m/z $297.4[M+1]^{+}, t_{R}=1.81 \mathrm{~min}$.

2-Bromo-N-(2-(trifluoromethyl)phenyl)acetamide (49). The compound was synthesized according to a previously described procedure ${ }^{92}$ with some deviations. A solution of 2-(trifluoromethyl)aniline $(0.63 \mathrm{~mL}$, $5.00 \mathrm{mmol}, 1.0$ equiv) and dry $\mathrm{Et}_{3} \mathrm{~N}(2.09 \mathrm{~mL}, 15.0 \mathrm{mmol}, 3.0$ equiv) in dry 1,4-dioxane $(10 \mathrm{~mL})$ was purged with nitrogen, stirred, and cooled to $0{ }^{\circ} \mathrm{C}$. Under nitrogen and at $0{ }^{\circ} \mathrm{C}$ was then dropwise added a solution of 2bromoacetyl bromide $(1.31 \mathrm{~mL}, 15.0 \mathrm{mmol}, 3.0$ equiv) in dry 1,4-dioxane $(10 \mathrm{~mL})$. The reaction mixture was 
stirred at RT for $2 \mathrm{~h}$, until TLC (heptane:EtOAc 1:1, $\mathrm{R}_{\mathrm{f}}$ 0.71) showed complete reaction. The reaction mixture was then poured into cold water $(10 \mathrm{~mL})$ and the resulting precipitate was filtered off, washed with water (10 mL), and oven-dried to furnish 49 as a brown solid (1.25 g, $4.43 \mathrm{mmol}, 89 \%)$. LC-MS: MS (ESI) m/z 282.3, $284.3\left(\mathrm{Br}\right.$ signal) $[\mathrm{M}+1]^{+}, \mathrm{t}_{\mathrm{R}}=2.04 \mathrm{~min}$.

3-((2-phenylquinazolin-4-yl)amino)-2-naphthoic acid (52). The compound was synthesized according to previously described general procedure. ${ }^{93} \mathrm{~A}$ solution of 4-chloro-2-phenylquinazoline $(0.50 \mathrm{~g}, 2.1 \mathrm{mmol}$, 1.0 equiv) and 3-amino-2-naphthoic acid ( $0.39 \mathrm{~g}, 2.1 \mathrm{mmol}, 1.0$ equiv) in $\mathrm{AcOH}(40 \mathrm{~mL})$ was stirred at reflux for $1 \mathrm{~h}$, until TLC (DCM:MeOH 5:1, $\mathrm{R}_{\mathrm{f}}$ 0.18) showed complete reaction. The reaction mixture was then cooled to RT before the suspension was filtered and the solid dried to furnish $\mathbf{5 2}$ as a yellow solid $(0.74 \mathrm{~g}, 1.90 \mathrm{mmol}, 91 \%)$. LC-MS: MS (ESI) m/z $392.2[M+1]^{+}, t_{R}=3.71 \mathrm{~min} .{ }^{1} \mathrm{H}$ NMR $\left(600 \mathrm{MHz}, \mathrm{DMSO}-d_{6}\right) \delta 12.35(\mathrm{~s}, 1 \mathrm{H}), 8.99(\mathrm{~s}, 1 \mathrm{H}), 8.79$ (s, $1 \mathrm{H}), 8.52(\mathrm{~d}, \mathrm{~J}=8.0 \mathrm{~Hz}, 1 \mathrm{H}), 8.40(\mathrm{~d}, \mathrm{~J}=7.4 \mathrm{~Hz}, 2 \mathrm{H}), 8.17(\mathrm{dd}, \mathrm{J}=8.0,2.9 \mathrm{~Hz}, 2 \mathrm{H}), 8.08(\mathrm{t}, \mathrm{J}=7.7 \mathrm{~Hz}, 1 \mathrm{H}), 8.04$ $(\mathrm{d}, \mathrm{J}=8.2 \mathrm{~Hz}, 1 \mathrm{H}), 7.86(\mathrm{t}, \mathrm{J}=7.6 \mathrm{~Hz}, 1 \mathrm{H}), 7.73(\mathrm{ddd}, \mathrm{J}=8.2,6.8,1.2 \mathrm{~Hz}, 1 \mathrm{H}), 7.67-7.60(\mathrm{~m}, 4 \mathrm{H})$.

5-Bromo-7-methoxy-1-methyl-1H-benzo[d][1,2,3]triazole (53). The compound was synthesized in five steps. For step 1, a previously described procedure ${ }^{27}$ was employed with no deviations. Starting from 2-amino3-nitrophenol (10.0 g, $64.9 \mathrm{mmol})$, 2-methoxy-6-nitroaniline (53-11) was obtained as an orange solid (9.73 g, $57.8 \mathrm{mmol}, 89 \%) .{ }^{1} \mathrm{H}$ NMR (600 MHz, Chloroform-d) $\delta 7.73(\mathrm{dd}, J=8.9,1.3 \mathrm{~Hz}, 1 \mathrm{H}), 6.88(\mathrm{dd}, J=7.7,1.2 \mathrm{~Hz}, 1 \mathrm{H})$, $6.61(\mathrm{dd}, J=8.9,7.8 \mathrm{~Hz}, 1 \mathrm{H}), 6.43(\mathrm{~s}, 2 \mathrm{H}), 3.92(\mathrm{~s}, 3 \mathrm{H}) .{ }^{13} \mathrm{C}$ NMR (151 MHz, Chloroform-d) $\delta 148.30,137.20$, $131.83,117.52,114.72,113.44,56.40$. For step 2 , a previously described procedure ${ }^{27}$ was employed with no deviations. Starting from 53-I1 (9.73 g, $57.8 \mathrm{mmol})$, 4-bromo-2-methoxy-6-nitroaniline (53-12) was obtained as an orange solid (12.64 g, $51.2 \mathrm{mmol}, 88 \%) .{ }^{1} \mathrm{H}$ NMR (600 MHz, DMSO- $\left.d_{6}\right) \delta 7.71(\mathrm{~d}, J=2.1 \mathrm{~Hz}, 1 \mathrm{H}), 7.24(\mathrm{~s}, 2 \mathrm{H})$, $7.20(\mathrm{~d}, J=2.1 \mathrm{~Hz}, 1 \mathrm{H}), 3.91(\mathrm{~s}, 3 \mathrm{H})$. For step 3, a previously described procedure ${ }^{27}$ was employed with no deviations. Starting from 53-12 (12.64 g, $51.2 \mathrm{mmol})$, 4-bromo-2-methoxy- $N$-methyl-6-nitroaniline (53-13) was obtained as an orange solid $(8.67 \mathrm{~g}, 33.2 \mathrm{mmol}, 65 \%) .{ }^{1} \mathrm{H}$ NMR (400 MHz, DMSO- $\left.d_{6}\right) \delta 7.59(\mathrm{~d}, J=2.2 \mathrm{~Hz}, 1 \mathrm{H}), 7.23$ $(\mathrm{s}, 3 \mathrm{H}), 7.18(\mathrm{~d}, J=2.3 \mathrm{~Hz}, 1 \mathrm{H}), 3.91(\mathrm{~s}, 2 \mathrm{H}), 3.87(\mathrm{~s}, 3 \mathrm{H}), 2.86(\mathrm{~d}, J=5.4 \mathrm{~Hz}, 3 \mathrm{H})$. For step 4, a previously described procedure ${ }^{27}$ was employed with minor deviations. To a solution of 53-13 (1.30 g, $5.0 \mathrm{mmol}, 1.0$ equiv) in 
EtOH $(25 \mathrm{~mL})$ was added $\mathrm{SnCl}_{2} \cdot 2 \mathrm{H}_{2} \mathrm{O}\left(4.49 \mathrm{~g}, 19.9 \mathrm{mmol}, 4.0\right.$ equiv) and the reaction mixture was stirred at $75^{\circ} \mathrm{C}$ for $2 \mathrm{~h}$. Then the mixture was adjusted to $\mathrm{pH} 14$ using $40 \%$ aq. $\mathrm{NaOH}$, followed by addition of water (150 mL), and extraction with EtOAc $(3 \times 100 \mathrm{~mL})$. The combined organic layers were dried over $\mathrm{Na}_{2} \mathrm{SO}_{4}$ and concentrated in vacuo. The crude was purified by flash chromatography (heptane:EtOAc, $0-100 \%$ gradient) to furnish 4bromo-6-methoxy-N1-methylbenzene-1,2-diamine (53-14) as an yellow solid (1.03 g, $4.6 \mathrm{mmol}, 90 \%) .{ }^{1} \mathrm{H}$ NMR (400 MHz, Chloroform-d) $\delta 6.54(\mathrm{~d}, J=2.0 \mathrm{~Hz}, 1 \mathrm{H}), 6.45(\mathrm{~d}, J=2.0 \mathrm{~Hz}, 1 \mathrm{H}), 4.11(\mathrm{~d}, J=67.7 \mathrm{~Hz}, 2 \mathrm{H}), 3.81(\mathrm{~s}, 3 \mathrm{H})$, $2.70(\mathrm{~s}, 3 \mathrm{H}), 0.07(\mathrm{~s}, 3 \mathrm{H})$. For step 5, a previously described procedure ${ }^{27}$ was followed with no deviations. Starting from 53-14 (1.03 g, $4.5 \mathrm{mmol}), 53$ was obtained as a brown solid (0.89 g, $3.7 \mathrm{mmol}, 83 \%) .{ }^{1} \mathrm{H} \mathrm{NMR}(600 \mathrm{MHz}$, Chloroform-d) $\delta 7.76(\mathrm{~d}, J=1.3 \mathrm{~Hz}, 1 \mathrm{H}), 6.85(\mathrm{~d}, J=1.3 \mathrm{~Hz}, 1 \mathrm{H}), 4.44(\mathrm{~s}, 3 \mathrm{H}), 3.99(\mathrm{~s}, 3 \mathrm{H})$.

Methyl (E)-3-(7-methoxy-1-methyl-1H-benzo[d][1,2,3]triazol-5-yl)acrylate (54). The compound was synthesized according to previously described procedure ${ }^{27}$ with minor deviations. To a solution of 53 (0.89 g, $3.7 \mathrm{mmol}, 1.0$ equiv) in dry DMF $(5 \mathrm{~mL})$, methyl acrylate $(1.66 \mathrm{~mL}, 18.4 \mathrm{mmol}, 5.0$ equiv), DIPEA (1.59 mL, $9.2 \mathrm{mmol}, 2.5$ equiv), and tri-o-phosphine $\left(0.22 \mathrm{~g}, 0.74 \mathrm{mmol}, 0.2\right.$ equiv) were added. Then $\mathrm{Pd}(\mathrm{OAc})_{2}(0.08 \mathrm{~g}$, $0.37 \mathrm{mmol}, 0.1$ equiv) was added. The reaction mixture was stirred at $95{ }^{\circ} \mathrm{C}$ for $4 \mathrm{~h}$ under an atmosphere of nitrogen. The reaction mixture was then poured into water $(10 \mathrm{~mL})$ and extracted with EtOAc $(2 \times 15 \mathrm{~mL})$. The resulting organic phase was concentrated in vacuo. The crude was purified by flash chromatography (heptane:EtOAc, $0-100 \%$ gradient) to furnish 54 as a brown solid $(0.31 \mathrm{~g}, 1.25 \mathrm{mmol}, 32 \%) .{ }^{1} \mathrm{H} \mathrm{NMR}(400 \mathrm{MHz}$, Chloroform-d) $\delta 7.84-7.68(\mathrm{~m}, 2 \mathrm{H}), 6.91(\mathrm{~d}, \mathrm{~J}=1.1 \mathrm{~Hz}, 1 \mathrm{H}), 6.45(\mathrm{~d}, \mathrm{~J}=15.9 \mathrm{~Hz}, 1 \mathrm{H}), 4.46(\mathrm{~s}, 3 \mathrm{H}), 4.02(\mathrm{~s}, 3 \mathrm{H}), 3.83(\mathrm{~s}$, $3 \mathrm{H})$.

Methyl 3-(3-(hydroxymethyl)-4-methylphenyl)-3-(7-methoxy-1-methyl-1H-benzo[d][1,2,3]triazol-5-

yl)propanoate (55). The compound was synthesized according to previously described procedure ${ }^{27}$ with no deviations. Starting from $54(0.15 \mathrm{~g}, 0.61 \mathrm{mmol}), 55$ was obtained as a white solid $(0.10 \mathrm{~g}, 0.27 \mathrm{mmol}, 46 \%) .{ }^{1} \mathrm{H}$ NMR (400 MHz, Chloroform-d) $\delta 7.48(\mathrm{~s}, 1 \mathrm{H}), 7.24(\mathrm{~s}, 1 \mathrm{H}), 7.10$ (d, J = 1.3 Hz, 2H), 6.62-6.54 (m, 1H), 4.67-4.63 $(\mathrm{m}, 3 \mathrm{H}), 4.41(\mathrm{~s}, 3 \mathrm{H}), 4.12(\mathrm{q}, \mathrm{J}=7.2 \mathrm{~Hz}, 1 \mathrm{H}), 3.91(\mathrm{~s}, 3 \mathrm{H}), 3.11(\mathrm{qd}, \mathrm{J}=15.7,7.8 \mathrm{~Hz}, 2 \mathrm{H}), 2.30(\mathrm{~s}, 3 \mathrm{H})$. 
(R)-2-Fluoro-N-(2-hydroxypropyl)benzenesulfonamide (56). The compound was synthesized according to previously described procedure ${ }^{27}$ with minor deviations. To a solution of $(R)$-1-aminopropan-2-ol $(0.2 \mathrm{~g}$, $2.7 \mathrm{mmol}, 1.0$ equiv) in THF/water $(1: 1,15 \mathrm{~mL})$ was slowly added $\mathrm{K}_{2} \mathrm{CO}_{3}(0.1 \mathrm{~g}, 2.7 \mathrm{mmol}, 1.0$ equiv) and then $2-$ fluorobenzenesulfonyl chloride $(0.88 \mathrm{~mL}, 2.7 \mathrm{mmol}, 1.0$ equiv). The reaction mixture was stirred at RT for $66 \mathrm{~h}$. The reaction mixture was then diluted with water $(15 \mathrm{~mL})$, extracted with EtOAc $(3 \times 15 \mathrm{~mL})$, and the combined organic layers washed with brine $(20 \mathrm{~mL})$, dried over $\mathrm{Na}_{2} \mathrm{SO}_{4}$, filtered, and concentrated in vacuo. The crude was purified by flash chromatography (heptane:EtOAc, 0-100\% gradient) to furnish 56 as a red oil (0.66 g, $2.8 \mathrm{mmol}$, quantitative). ${ }^{1} \mathrm{H} \mathrm{NMR}(600 \mathrm{MHz}$, Chloroform-d) $\delta 7.91(\mathrm{td}, \mathrm{J}=7.5,1.8 \mathrm{~Hz}, 1 \mathrm{H}), 7.63-7.55(\mathrm{~m}, 1 \mathrm{H})$, $7.29(\mathrm{td}, \mathrm{J}=7.7,1.1 \mathrm{~Hz}, 1 \mathrm{H}), 7.22$ (ddd, J = 10.3, 8.3, $1.1 \mathrm{~Hz}, 1 \mathrm{H}), 5.19(\mathrm{~s}, 1 \mathrm{H}), 3.94(\mathrm{~d}, \mathrm{~J}=8.0 \mathrm{~Hz}, 1 \mathrm{H}), 3.13(\mathrm{~d}, \mathrm{~J}=$ $12.9 \mathrm{~Hz}, 1 \mathrm{H}), 2.88-2.80(\mathrm{~m}, 1 \mathrm{H}), 1.89(\mathrm{~s}, 1 \mathrm{H}), 1.18(\mathrm{~d}, \mathrm{~J}=6.3 \mathrm{~Hz}, 3 \mathrm{H})$.

(R)-4-Methyl-3,4-dihydro-2H-benzo[b][1,4,5]oxathiazepine 1,1-dioxide (57). The compound was synthesized according to previously described procedure ${ }^{27}$ with no deviations. Starting from $\mathbf{5 6}$ (0.66 g, $\left.2.8 \mathrm{mmol}\right), 57$ was obtained as a white solid $\left(0.59 \mathrm{~g}, 2.8 \mathrm{mmol}\right.$, quantitative). LC-MS: MS (ESI) m/z $236.0[\mathrm{M}+1]^{+} .{ }^{1} \mathrm{H}$ NMR (400 MHz, Chloroform-d) $\delta 7.84(\mathrm{dd}, J=7.8,1.7 \mathrm{~Hz}, 1 \mathrm{H}), 7.46(\mathrm{td}, J=7.8,1.7 \mathrm{~Hz}, 1 \mathrm{H}), 7.23-7.12(\mathrm{~m}, 2 \mathrm{H}), 4.68(\mathrm{~s}$, 1H), 4.22-4.10 (m, 1H), $3.63(\mathrm{dt}, J=15.0,9.2 \mathrm{~Hz}, 1 \mathrm{H}), 3.42(\mathrm{ddd}, J=15.1,5.2,2.2 \mathrm{~Hz}, 1 \mathrm{H}), 1.40(\mathrm{~d}, J=6.4 \mathrm{~Hz}$, $3 \mathrm{H})$.

1-ethynyl-3-nitrobenzene (58). The compound was synthesized in two steps according to previously described procedure ${ }^{58}$ with some deviations. For step 1, a solution of 1-iodo-3-nitrobenzene $(2.47 \mathrm{~g}, 9.90 \mathrm{mmol}$, 1.0 equiv) in dry DMF $(5.0 \mathrm{~mL})$ and dry $\mathrm{Et}_{3} \mathrm{~N}(10.0 \mathrm{~mL})$ was degassed by bubbling through with nitrogen for $20 \mathrm{~min}$ in a microwave vial. Then Cul $\left(0.0075 \mathrm{~g}, 0.040 \mathrm{mmol}, 0.004\right.$ equiv), $\mathrm{Pd}\left(\mathrm{PPh}_{3}\right)_{4}(0.13 \mathrm{~g}, 0.11 \mathrm{mmol}$, 0.011 equiv), and TMS-acetylene (1.52 mL, $10.99 \mathrm{mmol}, 1.11$ equiv) were added. The vial was capped, subjected to three vacuum-nitrogen cycles, and then subjected to microwave irradiation at $120^{\circ} \mathrm{C}$ for $1 \mathrm{~h}$ (pre-stirring for $30 \mathrm{~s}$ ), until TLC (heptane:EtOAc 1:1, $R_{f}$ 0.87) showed complete reaction. The reaction mixture was then poured into aq. $1 \mathrm{M} \mathrm{HCl}(50 \mathrm{~mL})$ and extracted with $\mathrm{DCM}(2 \times 30 \mathrm{~mL})$. The combined organic phases were washed with aq. $1 \mathrm{M} \mathrm{HCl}(50 \mathrm{~mL})$ and sat. brine $(50 \mathrm{~mL})$, dried over $\mathrm{Na}_{2} \mathrm{SO}_{4}$, filtered, and concentrated to dry- 
ness in vacuo. The crude was purified by flash chromatography (heptane:EtOAc, 0-40\%) to furnish trimethyl((3nitrophenyl)ethynyl)silane (58-I1) as a golden-brown oil (0.53 g, $2.42 \mathrm{mmol}, 24 \%) .{ }^{1} \mathrm{H}$ NMR (400 MHz, Chloroform-d) $\delta 8.30(t, J=1.9 \mathrm{~Hz}, 1 \mathrm{H}), 8.16(\mathrm{ddd}, \mathrm{J}=8.3,2.3,1.1 \mathrm{~Hz}, 1 \mathrm{H}), 7.75(\mathrm{dt}, \mathrm{J}=7.7,1.3 \mathrm{~Hz}, 1 \mathrm{H}), 7.48(\mathrm{t}, \mathrm{J}=$ 8.0 Hz, 1H), 0.27 (s, 9H). ${ }^{13} \mathrm{C}$ NMR (101 MHz, Chloroform-d) $\delta$ 148.18, 137.68, 129.37, 126.94, 125.14, 123.27, 102.30, 97.79, -0.11. For step 2, to a solution of $58-11$ ( $0.53 \mathrm{~g}, 2.42 \mathrm{mmol}, 1.0$ equiv) in $\mathrm{MeOH}(25.0 \mathrm{~mL}) \mathrm{was}$ added $\mathrm{K}_{2} \mathrm{CO}_{3}(0.60 \mathrm{~g}, 4.36 \mathrm{mmol}, 1.80$ equiv). The solution was stirred under nitrogen at RT for $22 \mathrm{~h}$, until TLC (heptane:EtOAc 1:1, $R_{f} 0.77$ ) showed complete reaction. The reaction mixture was then concentrated in vacuo, the residue re-dissolved in EtOAc $(15 \mathrm{~mL})$, and the solution washed with water $(10 \mathrm{~mL})$, sat. brine $(10 \mathrm{~mL})$, dried over $\mathrm{Na}_{2} \mathrm{SO}_{4}$, filtered, and concentrated to dryness in vacuo to furnish $\mathbf{5 8}$ as a dark-brown oil $(0.35 \mathrm{~g}$, $2.38 \mathrm{mmol}, 97 \%) .{ }^{1} \mathrm{H}$ NMR (400 MHz, Chloroform-d) $\delta 8.34(\mathrm{t}, J=1.9 \mathrm{~Hz}, 1 \mathrm{H}), 8.20$ (ddd, J = 8.3, 2.3, $\left.1.1 \mathrm{~Hz}, 1 \mathrm{H}\right)$, $7.79(\mathrm{dt}, J=7.7,1.3 \mathrm{~Hz}, 1 \mathrm{H}), 7.52(\mathrm{t}, J=8.0 \mathrm{~Hz}, 1 \mathrm{H}), 3.22(\mathrm{~s}, 1 \mathrm{H}) .{ }^{13} \mathrm{C}$ NMR $(101 \mathrm{MHz}$, Chloroform-d) $\delta 148.25$, $137.92,129.54,127.15,124.09,123.73,81.25,80.05$.

1-azido-3-iodobenzene (59). The compound was synthesized according to previously described procedure ${ }^{58}$ with no deviations. Starting from 3-iodoaniline $(0.275 \mathrm{~mL}, 2.28 \mathrm{mmol}), 59$ was obtained as a goldenbrown non-viscous oil (0.49 g, $2.00 \mathrm{mmol}, 88 \%) .{ }^{1} \mathrm{H}$ NMR (600 MHz, DMSO- $\left.d_{6}\right) \delta 7.55(\mathrm{dt}, \mathrm{J}=7.7,1.3 \mathrm{~Hz}, 1 \mathrm{H})$, $7.46(t, J=1.9 \mathrm{~Hz}, 1 \mathrm{H}), 7.19(\mathrm{t}, \mathrm{J}=7.9 \mathrm{~Hz}, 1 \mathrm{H}), 7.14$ (ddd, J = 8.1, 2.2, $1.1 \mathrm{~Hz}, 1 \mathrm{H}) .{ }^{13} \mathrm{C}$ NMR $\left(151 \mathrm{MHz}, \mathrm{DMSO}-d_{6}\right)$ $\delta 140.94,133.76,131.67,127.40,118.69,95.46$.

Ethyl 2-(3-cyanophenoxy)acetate (60). The compound was synthesized according to the previously described procedure ${ }^{42}$ with some deviations. To a solution of 3-hydroxybenzonitrile (1.43 $\mathrm{g}, 12.0 \mathrm{mmol}$, 1.00 equiv) in acetone $(30 \mathrm{~mL})$ were added $\mathrm{K}_{2} \mathrm{CO}_{3}(2.49 \mathrm{~g}, 18.0 \mathrm{mmol}, 1.50$ equiv) and ethyl 2-bromoacetate (1.86 mL, $16.8 \mathrm{mmol}, 1.40$ equiv). The reaction mixture was stirred at reflux for $2 \mathrm{~h}$, until TLC (DCM:MeOH 20:1, $R_{f}$ 0.96) showed complete reaction. The reaction mixture was then filtered, and the filtrate concentrated to dryness in vacuo. The crude was purified by flash chromatography (heptane:EtOAc, 5-25\% gradient) to furnish 60 as a colorless oil $(1.00 \mathrm{~g}, 4.88 \mathrm{mmol}, 41 \%) .{ }^{1} \mathrm{H}$ NMR $\left(600 \mathrm{MHz}, \mathrm{DMSO}-\mathrm{d}_{6}\right) \delta 7.50(\mathrm{dd}, J=8.4,7.6 \mathrm{~Hz}, 1 \mathrm{H})$, 7.48-7.42 (m, 2H), $7.31(\mathrm{ddd}, J=8.4,2.8,1.0 \mathrm{~Hz}, 1 \mathrm{H}), 4.89(\mathrm{~s}, 2 \mathrm{H}), 4.18(\mathrm{q}, J=7.1 \mathrm{~Hz}, 2 \mathrm{H}), 1.22(\mathrm{t}, J=7.1 \mathrm{~Hz}$, 
4H). ${ }^{13} \mathrm{C}$ NMR (151 MHz, DMSO) $\delta$ 168.74, 158.26, 131.32, 125.62, 120.84, 118.98, 118.11, 112.67, 65.27, 61.24, 14.47.

2-(3-(Aminomethyl)phenoxy)acetic acid (61). The compound was synthesized in two steps according to previously described procedure ${ }^{42}$ with no deviations. For step 1, starting from 60 (2.18 g, $10.6 \mathrm{mmol}$, 1.00 equiv), 2-(3-cyanophenoxy)acetic acid (61-I1) was obtained as a white solid (1.50 g, $8.50 \mathrm{mmol}, 80 \%) .{ }^{1} \mathrm{H}$ NMR $\left(600 \mathrm{MHz}, \mathrm{DMSO}-\mathrm{d}_{6}\right) \delta$ 13.17-13.00 (m, 1H), 7.52-7.47 (m, 1H), 7.45-7.40 (m, 2H), 7.29 (ddd, J = 8.4, 2.5, $1.2 \mathrm{~Hz}, 1 \mathrm{H}), 4.79$ (s, 2H). ${ }^{13} \mathrm{C}$ NMR (151 MHz, DMSO) $\delta 170.18,158.40,131.29,125.40,120.77,119.03,118.05$, 112.61, 65.09. For step 2, starting from 61-11 (1.00 g, $5.64 \mathrm{mmol}), 61$ was obtained as a white solid $(0.92 \mathrm{~g}, 5.08$ mmol, 90\%). ${ }^{1} \mathrm{H}$ NMR (400 MHz, Methanol- $\left.d_{4}\right) \delta 7.22(\mathrm{t}, J=7.8 \mathrm{~Hz}, 1 \mathrm{H}), 6.94-6.81(\mathrm{~m}, 3 \mathrm{H}), 4.32(\mathrm{~s}, 2 \mathrm{H}), 3.95(\mathrm{~s}$, $2 \mathrm{H})$.

2,2,2-Trichloroethyl (5-(furan-2-yl)-1,3,4-oxadiazol-2-yl)carbamate (62). The compound was synthesized according to previously described procedure ${ }^{42}$ with no deviations. Starting from 5-(furan-2-yl)-1,3,4-oxadiazol2-amine (0.50 g, $3.31 \mathrm{mmol}, 1.00$ equiv) and 2,2,2-trichloroethyl carbonochloridate $(0.45 \mathrm{~mL}, 3.49 \mathrm{mmol}$, 1.05 equiv), 62 was obtained as a white solid (0.28 g, $0.86 \mathrm{mmol}, 26 \%)$. LC-MS: MS (ESI) m/z 326.3, 328.3, 330.3, $332.5[\mathrm{M}+1]^{+}$(due to $\mathrm{Cl}$ isotopes), $\mathrm{t}_{\mathrm{R}}=2.08 .{ }^{1} \mathrm{H}$ NMR $\left(600 \mathrm{MHz}, \mathrm{DMSO}-\mathrm{d}_{6}\right) \delta 12.30(\mathrm{~s}, 1 \mathrm{H}), 8.03(\mathrm{~d}, J=$ $1.7 \mathrm{~Hz}, 1 \mathrm{H}), 7.24(\mathrm{~d}, J=3.5 \mathrm{~Hz}, 1 \mathrm{H}), 6.78(\mathrm{dd}, J=3.5,1.8 \mathrm{~Hz}, 1 \mathrm{H}), 5.02(\mathrm{~s}, 2 \mathrm{H})$.

1H-benzo[d]imidazole-5-carbonitrile (63). The compound was synthesized according to a previously described procedure ${ }^{44}$ with no deviations. Starting from 3,4-diaminobenzonitrile (0.13 g, $\left.1.00 \mathrm{mmol}\right), 63$ was obtained (0.12 g, $0.85 \mathrm{mmol}, 85 \%)$. LC-MS: MS (ESI) m/z $144.2[\mathrm{M}+1]^{+}, \mathrm{t}_{\mathrm{R}}=1.37 \mathrm{~min}$.

$\mathrm{N}$-hydroxy-1H-benzo[d]imidazole-5-carboximidamide (64). The compound was synthesized according to a previously described procedure ${ }^{44}$ with some deviations. To a solution of $63(0.38 \mathrm{~g}, 2.65 \mathrm{mmol}, 1.00$ equiv) in abs. EtOH $(50 \mathrm{~mL})$ was added a solution of $\mathrm{NH}_{2} \mathrm{OH}(0.44 \mathrm{~mL}$ of $50 \mathrm{w} / \mathrm{w} \%$ aq. solution, $5.31 \mathrm{mmol}, 2.00$ equiv). The reaction mixture was stirred at reflux for $72 \mathrm{~h}$, until LC-MS showed complete reaction. The reaction mixture was then concentrated to dryness in vacuo to furnish $\mathbf{6 4}$, used for further synthesis without purification. LC-MS: MS (ESI) m/z $177.3[M+1]^{+}, t_{R}=0.48 \mathrm{~min}$. 
Expression and purification of the Keap1 Kelch domain. The recombinant His-tagged human Kelch domain (residue 321-609, UniProt Q14145) was cloned into a pRSET A and expressed in E. coli BL21 (DE3) pLysS. Keap1 was grown in a pre-culture of $50 \mathrm{~mL}$ LB media supplemented with $1 \%$ glucose and $100 \mu \mathrm{g} / \mathrm{mL}$ ampicillin overnight (ON) at $37{ }^{\circ} \mathrm{C}$ to an approximate $\mathrm{OD}_{600}$ of $\sim 1.0$. The pre-culture was transferred to $1 \mathrm{~L} \mathrm{LB}$-medium supplemented with $1 \%$ glucose and $100 \mu \mathrm{g} / \mathrm{mL}$ ampicillin and grown at $37{ }^{\circ} \mathrm{C} / 180 \mathrm{rpm}$ to an approximate $\mathrm{OD}_{600}$ of $\sim 0.5$, before induction with isopropyl $\beta$-D-1-thiogalactopyranoside (IPTG) (final concentration of 0.5-1 mM) $\mathrm{ON}$ at $15{ }^{\circ} \mathrm{C} / 180 \mathrm{rpm}$. Cells were harvested by centrifugation at $4,000 \times \mathrm{g}$ for $30 \mathrm{~min}$. The cells were resuspended in lysis buffer (50 mM HEPES pH 7.5, cOmplete ${ }^{\mathrm{TM}}$ Protease Inhibitor Cocktail (1 tablet/50 mL of buffer), $25 \mu \mathrm{g} / \mathrm{mL}$ DNase, $40 \mathrm{mM} \mathrm{Mg} \mathrm{SO}_{4}, 150 \mathrm{mM} \mathrm{NaCl}, 5 \mathrm{mM}$ imidazole, 5\% glycerol, 0.5\% TritonX-100, $3 \mathrm{mM}$ DTT, $1 \mathrm{mg} / \mathrm{mL}$ Lysozyme) and lysed using a cell disruptor at $26 \mathrm{KPsi}$ in $4{ }^{\circ} \mathrm{C}$. The cell lysate was spun down at $35,000 \times g$ for $1 \mathrm{~h}$ at $4{ }^{\circ} \mathrm{C}$. The supernatant was filtered on a $0.45 \mu \mathrm{m}$ filter and loaded onto a $5 \mathrm{~mL}$ HisTrap HP column (GE Healthcare). The column was washed with 5 column volumes of HisTrap binding buffer (50 mM HEPES pH 7.5, $150 \mathrm{mM} \mathrm{NaCl}, 10 \mathrm{mM}$ imidazole, $3 \mathrm{mM} \mathrm{DTT}$ ) followed by eluting the protein using a gradient of HisTrap elution buffer (50 mM HEPES pH 7.5, $150 \mathrm{mM} \mathrm{NaCl}, 1 \mathrm{M}$ imidazole, $3 \mathrm{mM}$ DTT). The protein was eluted between 5 and $10 \%$ elution buffer and concentrated to $5 \mathrm{~mL}$. The protein was loaded onto a Superdex 75 16/600 column (GE Healthcare), equilibrated with SEC buffer ( $25 \mathrm{mM} \mathrm{HEPES} \mathrm{pH} \mathrm{7.5,} 150 \mathrm{mM} \mathrm{NaCl}, 1 \mathrm{mM}$ TCEP) with a flow rate at $1 \mathrm{~mL} / \mathrm{min}$, and was eluted at $65 \mathrm{~mL}$. Protein was concentrated to $12 \mathrm{mg} / \mathrm{mL}$ and stored at $80{ }^{\circ} \mathrm{C}$. The protein was analyzed on SDS page for purity, and the concentration was measured by absorbance (Nanodrop) using a molar extinction coefficient calculated based on amino acid sequence. The exact molecular weight of purified Keap1 was confirmed by LC-MS.

Peptides and fluorescent peptide probes. Peptides 1 (LDEETGEFL-OH), 2 (Ac-LDEETGEFL-OH), and the FITC-Nrf2 peptide probe (FITC- $\beta$-DEETGEF-OH; $\beta=$ beta-alanine) were purchased from Biomatik (Canada). The FAM-Nrf2 (5(6)-FAM-LDEETGEFL-NH ${ }_{2}$ ) and Cy5-Nrf2 (Cy5-LDEETGEFL-NH 2 ) peptide probes were synthesized inhouse by solid-phase peptide synthesis as previously described, ${ }^{94-96}$ starting from a Rink amide MBHA resin 
preloaded with Fmoc-Leu. The FAM-Nrf2 probe was generated by coupling 5(6)-carboxyfluorescein (5(6)-FAM) to the $N$-terminal amino group of the Fmoc-deprotected and resin-attached LDEETGEFL peptide using HATU as coupling reagent and collidine as base (resin/FAM/HATU/collidine: 0.25/0.5/0.5/0.75 mmol; in $2 \mathrm{~mL}$ DMF), followed by cleavage from the resin by treatment with trifluoroacetic acid (TFA)/water/triisopropylsilane (TIPS) (90/5/5) for 2 h, evaporation in vacuo, cold ether precipitation, and HPLC purification. The Cy5-Nrf2 probe was synthesized by coupling Sulfo-Cy5-NHS ester (Lumiprobe, Germany) to the $N$-terminal amino group of the peptide LDEETGEFL-NH 2 in solution followed by HPLC purification. The reaction was performed in a 1:1.15 molar ratio of peptide $(1.29 \mathrm{mg})$ and dye in PBS buffer $(\mathrm{pH} 8.4)$ with $10 \%$ DMSO for $3 \mathrm{~h}$ at room temperature. All final peptides (both purchased and in-house synthesized) were characterized for purity (> 98\%) by LC-MS (mass, $\left.\mathrm{UV}_{214}, \mathrm{UV}_{254}, \mathrm{ELS}\right)$.

Fluorescence polarization (FP) assay. The binding affinities between fluorescent peptide probes (Cy5Nrf2, FAM-Nrf2, FITC-Nrf2) and the Keap1 Kelch domain were determined as $K_{d}$ values by saturation binding experiments, where increasing concentrations of Keap1 Kelch (0-300 nM) were added to a fixed concentration of peptide probe ( $3 \mathrm{nM}$ ). The assay was performed in a $1 \times$ HBSTET buffer ( $10 \mathrm{mM}$ HEPES, $150 \mathrm{mM} \mathrm{NaCl}, 0.005 \%$ Tween20, 3 mM EDTA, 1 mM TCEP, pH = 7.4) using black flat-bottom 384-well plates (Corning Life Sciences, NY), a volume of $30 \mu \mathrm{L} /$ well, and a final DMSO concentration of $4 \%$ or $8 \%$. The assay plate was spun-down to ascertain proper mixing and removal of potential air bubbles and incubated for 10-15 min at room temperature before measuring the FP levels on a Safire2 plate-reader (Tecan, Männedorf, Switzerland). The g-factor was adjusted at each experiment so that a series of three blank wells containing probe but no Keap1 Kelch defined the baseline FP value. The Cy5-Nrf2, FAM-Nrf2, and FITC-Nrf2 probes were measured at excitation/emission values of $635 / 670 \mathrm{~nm}, 470 / 525 \mathrm{~nm}$, and $470 / 535 \mathrm{~nm}$, respectively. The FP values were fitted to the one-site specific binding equation: $Y=B \max \times X /\left(K_{d}+X\right)$, with Bmax being the maximal FP value, $X$ the Keap1 Kelch concentration, and $\mathrm{Y}$ the variable FP values. The $K_{\mathrm{d}}$ values were derived from the resulting binding saturation curve as being equal to the Keap1 Kelch concentration, where the curve is half-saturated. The affinities between non- 
fluorescent Keap1 inhibitors (small-molecules and peptides) and Keap1 Kelch were determined as $K_{\mathrm{i}}$ values in a heterologous competition FP binding assay. This was done by adding increasing concentration of test compound ( 2 -fold serial dilutions, 12 concentrations tested per inhibition curve as duplicates) to a fixed concentration of Keap1 Kelch (14 nM when tested with the Cy5/FAM probes; $50 \mathrm{nM}$ when tested with the FITC probe) and peptide probe ( $3 \mathrm{nM}$ ) in the same HBSTET buffer and conditions as described above (final DMSO concen-

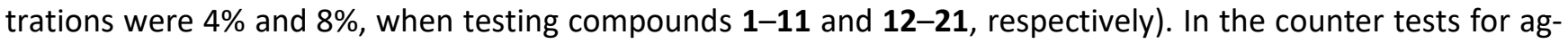
gregation, Tween 20 was either omitted from the assay buffer or replaced with $0.01 \%, 0.02 \%$, or $0.05 \%$ Triton $\mathrm{X}-100$. FP values were fitted to the equation $\mathrm{Y}=$ Bottom $+($ Top - Bottom $) /\left[1+\left(10^{\text {Hillslope }{ }^{*}(\text { LoglC50-X) })}\right]\right.$, where $X$ is the logarithmic value of compound concentration. Hereby, the $\mathrm{IC}_{50}$ value was obtained, which together with the $K_{\mathrm{d}}$ value and probe and Keap1 Kelch concentrations was used to calculate the theoretical competitive inhibition constant, the $K_{\mathrm{i}}$ value. ${ }^{65}$ All $K_{\mathrm{d}}$ and $K_{\mathrm{i}}$ values are shown as mean \pm SEM (standard error of mean) and are based on at least three individual measurements.

Thermal Shift Assay (TSA). Melting curves of Keap1 with and without the presence of compounds were determined by TSA using the Sypro Orange dye (Life Technologies), a Stratagene Mx3005P RT-PCR apparatus (Agilent Technologies, Waldbronn, Germany), and clear non-skirted 96-well PCR-plates. Keap1 Kelch (final concentration: $0.1 \mathrm{mg} / \mathrm{mL} ; 3 \mu \mathrm{M}$ ) and Sypro Orange (final concentration: $8 \mathrm{x}$ ) were mixed with compounds tested in 9 concentrations as 2-fold dilutions in assay buffer (10 mM HEPES, $150 \mathrm{mM} \mathrm{NaCl}, 0.005 \%$ Tween20, $3 \mathrm{mM}$ EDTA, $1 \mathrm{mM}$ TCEP, $\mathrm{pH}=7.4$ ), constant DMSO concentration of $4 \%$ (compounds $\mathbf{1 - 1 1}$ ) or $8 \%$ (compounds $\mathbf{1 2 -}$ 21), and final sample volume of $25 \mu \mathrm{L} /$ well. Each compound was tested in duplicates in three to four independent experiments. On each plate, 12 wells of DMSO blanks and 12 wells of positive controls were included for reference. The plates were sealed and spun-down for 2 minutes at $500 \times$ g, and measured from $25-95{ }^{\circ} \mathrm{C}$ in 70 cycles with a $1{ }^{\circ} \mathrm{C}$ temperature increase per minute and fluorescence intensities measured at each cycle. The sigmoidal plot of the normalized fluorescence intensity values versus temperature were fitted to the Boltzmann equation $\mathrm{Y}=$ Bottom $+($ Top-Bottom $) /\left(1+\exp \left(\left(T_{m}-X\right) /\right.\right.$ Slope $\left.)\right)$, where $\mathrm{X}$ is temperature in ${ }^{\circ} \mathrm{C}$, whereby the 
melting temperature $\left(T_{m}\right)$, where $50 \%$ of protein is denatured, was determined. The difference in $T_{m}\left(\Delta T_{m}\right)$ of each compound concentration compared to DMSO blanks were plotted as dose-response curves and fitted to the equation $\Delta \mathrm{T}_{\mathrm{m}}=\Delta \mathrm{T}_{\mathrm{m}}-\max \times \mathrm{X} /\left(\mathrm{EC}_{50}+\mathrm{X}\right)$, with $\Delta \mathrm{T}_{\mathrm{m}}$-max being the maximal obtained $\mathrm{T}_{\mathrm{m}}$ and $\mathrm{X}$ the compound concentration. The $\mathrm{EC}_{50}$ values were then derived from the resulting curve as being equal to the compound concentration resulting in a $\Delta \mathrm{T}_{\mathrm{m}}$ half that of $\Delta \mathrm{T}_{\mathrm{m}}$-max.

Surface plasmon resonance (SPR). SPR measurements were performed at $25^{\circ} \mathrm{C}$ using a Pioneer FE instrument (PALL FortéBio). The Keap1 Kelch domain was covalently immobilized on biosensor chips by amine coupling up to a level between 4190-4300 RU, using a $10 \mathrm{mM} \mathrm{NaOAc}$ pH 5 immobilization buffer. A HBS-EP running buffer (20 mM HEPES, $300 \mathrm{mM} \mathrm{NaCl}, 1 \mathrm{mM}$ EDTA, 0.005\% Tween 20, 1 mM TCEP) supplemented with either $2 \%$ or $4 \%$ DMSO was used for the experiments. Micro calibration (low limit $1.5 \%$ or $3.5 \%$ and high limit $3 \%$ or $4.5 \%$, respectively) was performed for all SPR experiments to adjust for DMSO bulk effects. The compounds were injected in 7-8 concentrations (two-fold serial dilution) or in a gradient using the OneStep injection at $30 \mu \mathrm{L} / \mathrm{min}$ flow rate over immobilized Keap1. When required (compounds binding with slow off rate), the surface was regenerated after each analyte injection using $1 \mathrm{M} \mathrm{NaCl}$. The data were analyzed using Qdat Data Analysis Tool version 2.6.3.0 (PALL FortéBio). The sensorgrams were corrected for buffer effects and unspecific binding to the chip matrix by subtraction of blank and reference surface (a blank flow cell channel activated by injection of EDC/NHS and inactivated by injection of ethanolamine). The dissociation constants $\left(K_{\mathrm{d}}\right)$ were estimated either by plotting responses at equilibrium $\left(R_{\text {eq }}\right)$ against the injected concentration and curve fitted to a Langmuir (1:1) binding isotherm or by kinetic global fit of SPR sensorgrams to a simple 1:1 interaction model.

NAD(P)H quinone oxidoreductase 1 (NQO1 activity) in Hepa1c1c7 cells. Hepa1c1c7 cells (ECACC 95090613) were seeded in tissue-culture coated 96-well plates at a density of $1.0 \times 10^{4}$ cells/well in $200 \mu \mathrm{L}$ culture medium consisting of minimum essential medium eagle-alpha modification (without nucleosides) 
supplemented with $2 \mathrm{mM}$ glutamine, $10 \%$ fetal bovine serum, 100 units $/ \mathrm{mL}$ of penicillin and $100 \mu \mathrm{g} / \mathrm{mL}$ of streptomycin. The cells were grown for $24 \mathrm{~h}$ in a humidified incubator at $37{ }^{\circ} \mathrm{C}, 5 \% \mathrm{CO}_{2}$. Compounds to be tested as inducers were diluted into the culture medium in three different concentrations $(1,5$, and $10 \mu \mathrm{M})$ so that

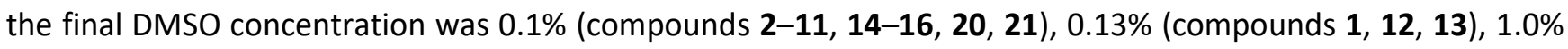
(compounds 17 and 19), and 1.4\% (compound 18). The cells were then incubated for an additional $24 \mathrm{~h}$. All compounds were tested in duplicates in four to seven independent experiments. Each plate included nonenzymatic blanks and at least 8 control wells with cells fed with media containing indicated doses of DMSO. The compounds were evaluated along with the prototype Nrf2 inducing agent sulforaphane (SFN) as a positive control reference. ${ }^{40,97}$ After the plates were exposed to test compounds, the culture medium was removed and the cells lysed by agitation on an orbital shaker (100 rpm) for 15 min at $25^{\circ} \mathrm{C}$ with $50 \mu \mathrm{L}$ per well of lysis buffer containing $0.1 \%$ Tween 20 in 2 mM EDTA, pH 7.5. Then, a complete enzyme reaction mixture was prepared with $25 \mathrm{mM}$ Tris- $\mathrm{HCl}(\mathrm{pH} 7.5)$, bovine serum albumin (0.067\%), Tween 20 (0.01\%), flavine adenine dinucleotide $(5 \mu \mathrm{M})$, glucose-6-phosphate (1 mM), NADP (30 $\mu \mathrm{M})$, MTT (0.03\%), menadione (50 $\mu \mathrm{M})$, glucose-6-phosphate dehydrogenase (300 units) and water to a final volume of $150 \mathrm{~mL}$, after which $200 \mu \mathrm{l} /$ well of the enzyme reaction mixture was added. The reaction was arrested after $5 \mathrm{~min}$ at $25^{\circ} \mathrm{C}$ by the addition of $40 \mu \mathrm{L} /$ well stop solution (10\% SDS). The plates were shaken for $5 \mathrm{~s}$ before the absorbance was monitored at $595 \mathrm{~nm}$ using a Safire2 plate-reader (Tecan, Männedorf, Switzerland). The average absorbance values of the non-enzymatic blank (lysis buffer, enzyme reaction mixture and stop solution) were subtracted from all other absorbance readings. Data for the untreated DMSO control were normalized as 1, and NQO1 activity induction (compound treated/DMSO control) was calculated. The presented results are expressed as the ratio of the NQO1 activity in cells from treated over positive control (SFN $10 \mu \mathrm{M}$ ) wells.

Covalent reactivity assay. Compounds were tested for reactivity towards GSH following a previously described protocol. ${ }^{75}$ The compound stocks (1.0 equiv) were incubated at room temperature with GSH (2.0 equiv) in assay buffer (10 mM HEPES, $150 \mathrm{mM} \mathrm{NaCl}, 3 \mathrm{mM}$ EDTA, $\mathrm{pH}=7.4$ ) with and without $1 \mathrm{mM}$ TCEP. Final com- 
pound concentrations were $500 \mu \mathrm{M}$ and incubation times were 10-30 min before analysis by UPLC-MS. UPLCMS spectra were obtained with a Waters ACQUITY QDa single quadrupole mass detector using ESI coupled to a Waters ACQUITY H-class UPLC system with a C18 reverse phase column (Acquity UPLC BEH C18, $2.1 \mathrm{~mm} \times$ $50 \mathrm{~mm}, 1.7 \mu \mathrm{m})$, a Sample Manager FTN and a TUV dual wavelength detector, using a linear gradient of the binary solvent system of buffer $\mathrm{A}$ (milliQ $\mathrm{H}_{2} \mathrm{O}: \mathrm{MeCN}$ :formic acid, 95:5:0.1 v/v\%) to buffer $\mathrm{B}$ (MeCN:formic acid, 100:0.1 v/v\%) from 0 to $100 \%$ B in $3.5 \mathrm{~min}$, then $1 \mathrm{~min}$ at $100 \% \mathrm{~B}$, maintaining a flow rate of $0.8 \mathrm{~mL} / \mathrm{min}$. Sample injection volume was $1 \mathrm{uL}$. The samples were monitored by TIC and UV. The spectra were analyzed using the Waters OpenLynx browser ver. 4.1.

Compounds were tested for reactivity towards the Keap1 Kelch domain using a similar protocol. The compound stocks (400 equiv) were incubated at room temperature with the Kelch domain (1.0 equiv) in the same assay buffer with $1 \mathrm{mM}$ TCEP. Final compound concentrations were $800 \mu \mathrm{M}$. Compounds that showed reactivity or which significantly overlapped with protein signals in the LC-MS spectrum were also tested in 1, 10, and 100 equiv $(2,20$, and $200 \mu \mathrm{M})$. Incubation times were $1-3 \mathrm{~h}$ before analysis by LC-MS. LC-MS spectra were obtained with the LC-MS system described above but here using a Poroshell C18 reverse phase column (Agilent, Poroshell, 300SB-C18, $2.1 \times 75 \mathrm{~mm}$ ) and a linear gradient of the binary solvent system from 0 to $60 \%$ B over 6 min. The samples were monitored by TIC, UV, and ELS. The spectra were analyzed using the Agilent MassHunter Qualitative Analysis software version B.01.03 and the protein mass spectra deconvoluted using the Agilent MassHunter Protein Deconvolution Software plugin.

Redox activity assay. The assay was performed as described by Johnston et al., ${ }^{81}$ except that 96 -well plates and a final volume of $120 \mu \mathrm{L} /$ well were used here. Compounds were tested as 2 -fold serial dilutions (12 concentrations) and a final constant DMSO concentration of $4 \%$ (compounds $\mathbf{1 - 1 1}$ ) or $\mathbf{8 \%}$ (12-21). Hydrogen peroxide (31-1000 $\mu \mathrm{M})$ and 3-methyltoxoflavin (0.2-400 $\mu \mathrm{M})$ were used as positive controls. Hank's Balanced Salt Solution (HBSS) from Sigma-Aldrich (cat\# H9269) was used as assay buffer. After preparing the compound dilutions in HBSS supplemented with DMSO ( $40 \mu \mathrm{L} /$ well), $40 \mu \mathrm{L}$ of a HBSS containing $3 \mathrm{mM}$ TCEP was added to 
each well, followed by $15 \mathrm{~min}$ incubation at room temperature. Detection reagent was prepared by dissolving $6 \mathrm{mg}$ phenol red and $3.6 \mathrm{mg}$ horseradish peroxidase (Sigma-Aldrich, cat\# P2088-5KU) with $20 \mathrm{~mL}$ HBSS, and $40 \mu \mathrm{L}$ was added to each well followed by 45 min incubation at room temperature and assay quenching by addition of $10 \mu \mathrm{L} \mathrm{NaOH}(1 \mathrm{M})$ per well. Absorbance was measured at $610 \mathrm{~nm}$ using the Safire2 plate-reader. Absorbance values from blank wells (i.e. wells without redox-active compounds, but subjected to the protocol) were subtracted from the compounds' absorbance values. For active compounds, a control test was done by omitting TCEP from the protocol and subtracting the resulting values from a parallel experiment with TCEP to account for potential background absorbance from compounds at $610 \mathrm{~nm}$. 


\section{ASSOCIATED CONTENT}

\section{Supporting Information.}

Schemes S1-4 (synthesis of compound 9, 12, 14, and 16, respectively), Supporting figures S1-8 (NMR characterization of an intermediate in the synthesis of 10, FP control experiments, Mimicking litera ture FP procedures, TSA melting curves, SPR sensorgrams, Counter assays), and quality control of tested compounds (NMR spectra) (PDF)

Molecular formula strings (CSV)

\section{AUTHOR INFORMATION}

\section{Corresponding Author}

*Email: anders.bach@sund.ku.dk; Phone: +45 21288604.

\section{ORCID}

Anders Bach: 0000-0003-4305-9910

\section{Present author addresses}

\#Novo Nordisk Foundation Center for Protein Research, Faculty of Health and Medical Sciences, University of Copenhagen, Blegdamsvej 3B, DK-2200 Copenhagen, Denmark

${ }^{\ddagger}$ Department of Pharmaceutical, Chemical and Environmental Sciences, The University of Greenwich, Chatham Maritime, UK-ME4 4TB Kent, United Kingdom

\section{Author Contributions}

"These authors contributed equally. The manuscript was written through contributions of all authors. All authors have given approval to the final version of the manuscript.

\section{Notes}

The authors declare no competing financial interests. 


\section{ACKNOWLEDGEMENTS}

This research was supported by the Lundbeck Foundation (Grant R190-2014-3710 for A.B.; and the Drug Research Academy/Lundbeck Foundation scholarship for K.T.T.); the China Scholarship Council (File no. 2017062200 for J.Z.); the A.P. Møller Foundation for the Advancement of Medical Science (Grant 14-28 for A.B.); the Hørslev Foundation (Grant 203866-MIA for A.B.); and the Augustinus Foundation (Grant 14-1571 and Grant 16-2677 for A.B.). NMR equipment used in this work was purchased via grant \#10-085264 from The Danish Research Council for Independent Research | Nature and Universe.

\section{ABBREVIATIONS}

PPI, protein-protein interaction; Nrf2, nuclear factor erythroid 2-related factor 2; Keap1, Kelch-like ECHassociated protein 1; NQO1, NAD(P)H:quinone oxidoreductase 1; heme oxygenase (HO-1); Cul3, cullin 3; BTB, broad complex, tramtrack, and bric-à-brac; IVR, intervening region; Neh2, Nrf2-ECH homology 2; ARE, antioxidant response element; CNS, central nervous system; CNS MPO, CNS multiparameter optimization; tPSA, topological polar surface area; HBD, hydrogen bond donors; BBB, blood-brain barrier; PAINS, pan-assay interference compounds; FP, fluorescence polarization; TSA, thermal shift assay; SPR, surface plasmon resonance; $\mathrm{S}_{N} A r$, nucleophilic aromatic substitution; qHNMR, 1D ${ }^{1} \mathrm{H}$ NMR; FITC, fluorescein isothiocyanate; FAM, 5(6)carboxyfluorescein; TAMRA, 5(6)-carboxytetramethylrhodamine; FLINT, total fluorescence intensity; TCEP, tris(2-carboxyethyl)phosphine; GSH, glutathione; Redox cycling compounds (RCCs). 


\section{REFERENCES}

1. Itoh, K.; Chiba, T.; Takahashi, S.; Ishii, T.; Igarashi, K.; Katoh, Y.; Oyake, T.; Hayashi, N.; Satoh, K.; Hatayama, I.; Yamamoto, M.; Nabeshima, Y. An Nrf2/small maf heterodimer mediates the induction of phase II detoxifying enzyme genes through antioxidant response elements. Biochem. Biophys. Res. Commun. 1997, 236 (2), 313-322.

2. Itoh, K.; Wakabayashi, N.; Katoh, Y.; Ishii, T.; Igarashi, K.; Engel, J. D.; Yamamoto, M. Keap1 represses nuclear activation of antioxidant responsive elements by Nrf2 through binding to the amino-terminal Neh2 domain. Genes Dev. 1999, 13 (1), 76-86.

3. Tonelli, C.; Chio, I. I. C.; Tuveson, D. A. Transcriptional regulation by Nrf2. Antioxid. Redox Signal. 2018, 29 (17), 1727-1745.

4. Cullinan, S. B.; Gordan, J. D.; Jin, J.; Harper, J. W.; Diehl, J. A. The Keap1-BTB protein is an adaptor that bridges Nrf2 to a Cul3-based E3 ligase: oxidative stress sensing by a Cul3-Keap1 ligase. Mol. Cell. Biol. 2004, 24 (19), 8477-8486.

5. Tong, K. I.; Katoh, Y.; Kusunoki, H.; Itoh, K.; Tanaka, T.; Yamamoto, M. Keap1 recruits Neh2 through binding to ETGE and DLG motifs: characterization of the two-site molecular recognition model. Mol. Cell. Biol. 2006, 26 (8), 2887-2900.

6. Canning, P.; Cooper, C. D.; Krojer, T.; Murray, J. W.; Pike, A. C.; Chaikuad, A.; Keates, T.; Thangaratnarajah, C.; Hojzan, V.; Ayinampudi, V.; Marsden, B. D.; Gileadi, O.; Knapp, S.; von Delft, F.; Bullock, A. N. Structural basis for Cul3 protein assembly with the BTB-Kelch family of E3 ubiquitin ligases. J. Biol. Chem. 2013, 288 (11), 7803-7814.

7. Fukutomi, T.; Takagi, K.; Mizushima, T.; Ohuchi, N.; Yamamoto, M. Kinetic, thermodynamic, and structural characterizations of the association between Nrf2-DLGex degron and Keap1. Mol. Cell. Biol. 2014, 34 (5), 832-846. 
8. McMahon, M.; Thomas, N.; Itoh, K.; Yamamoto, M.; Hayes, J. D. Dimerization of substrate adaptors can facilitate cullin-mediated ubiquitylation of proteins by a "tethering" mechanism: a two-site interaction model for the Nrf2-Keap1 complex. J. Biol. Chem. 2006, 281 (34), 24756-24768.

9. Baird, L.; Dinkova-Kostova, A. T. The cytoprotective role of the Keap1-Nrf2 pathway. Arch. Toxicol. 2011, 85 (4), 241-272.

10. Pallesen, J. S.; Tran, K. T.; Bach, A. Non-covalent small-molecule Kelch-like ECH-associated protein 1nuclear factor erythroid 2-related factor 2 (Keap1-Nrf2) inhibitors and their potential for targeting central nervous system diseases. J. Med. Chem. 2018, 61 (18), 8088-8103.

11. Kobayashi, A.; Kang, M. I.; Watai, Y.; Tong, K. I.; Shibata, T.; Uchida, K.; Yamamoto, M. Oxidative and electrophilic stresses activate Nrf2 through inhibition of ubiquitination activity of Keap1. Mol. Cell. Biol. 2006, 26 (1), 221-229.

12. Yamamoto, M.; Kensler, T. W.; Motohashi, H. The Keap1-Nrf2 system: a thiol-based sensor-effector apparatus for maintaining redox homeostasis. Physiol. Rev. 2018, 98 (3), 1169-1203.

13. Bach, A. Targeting Oxidative Stress in Stroke. In Neuroprotective Therapy for Stroke and Ischemic Disease, Lapchak, P. A.; Zhang, J. H., Eds. Springer: 2017; pp 203-250.

14. Cuadrado, A.; Rojo, A. I.; Wells, G.; Hayes, J. D.; Cousin, S. P.; Rumsey, W. L.; Attucks, O. C.; Franklin, S.; Levonen, A. L.; Kensler, T. W.; Dinkova-Kostova, A. T. Therapeutic targeting of the Nrf2 and Keap1 partnership in chronic diseases. Nat. Rev. Drug Discov. 2019, 18 (4), 295-317.

15. Sun, Y.; Yang, T.; Leak, R. K.; Chen, J.; Zhang, F. Preventive and protective roles of dietary Nrf2 activators against central nervous system diseases. CNS Neurol. Disord. Drug Targets 2017, 16 (3), 326-338.

16. Lakhan, S. E.; Kirchgessner, A.; Hofer, M. Inflammatory mechanisms in ischemic stroke: therapeutic approaches. J. Transl. Med. 2009, 7.

17. Johnson, J. A.; Johnson, D. A.; Kraft, A. D.; Calkins, M. J.; Jakel, R. J.; Vargas, M. R.; Chen, P. C. The Nrf2-ARE pathway: an indicator and modulator of oxidative stress in neurodegeneration. Ann. N. Y. Acad. Sci. 2008, 1147, 61-69. 
18. Tu, J.; Zhang, X.; Zhu, Y.; Dai, Y.; Li, N.; Yang, F.; Zhang, Q.; Brann, D. W.; Wang, R. Cell-permeable peptide targeting the Nrf2-Keap1 interaction: a potential novel therapy for global cerebral ischemia. J. Neurosci. 2015, 35 (44), 14727-14739.

19. Zhao, X.; Sun, G.; Zhang, J.; Ting, S. M.; Gonzales, N.; Aronowski, J. Dimethyl fumarate protects brain from damage produced by intracerebral hemorrhage by mechanism involving Nrf2. Stroke 2015, 46 (7), 19231928.

20. Zhao, J.; Redell, J. B.; Moore, A. N.; Dash, P. K. A novel strategy to activate cytoprotective genes in the injured brain. Biochem. Biophys. Res. Commun. 2011, 407 (3), 501-506.

21. Lu, M. C.; Ji, J. A.; Jiang, Z. Y.; You, Q. D. The Keap1-Nrf2-ARE pathway as a potential preventive and therapeutic target: an update. Med. Res. Rev. 2016, 36 (5), 924-963.

22. Jiang, Z. Y.; Lu, M. C.; Xu, L. L.; Yang, T. T.; Xi, M. Y.; Xu, X. L.; Guo, X. K.; Zhang, X. J.; You, Q. D.; Sun, H. P. Discovery of potent Keap1-Nrf2 protein-protein interaction inhibitor based on molecular binding determinants analysis. J. Med. Chem. 2014, 57 (6), 2736-2745.

23. Chen, Y.; Inoyama, D.; Kong, A. N.; Beamer, L. J.; Hu, L. Kinetic analyses of Keap1-Nrf2 interaction and determination of the minimal Nrf2 peptide sequence required for Keap1 binding using surface plasmon resonance. Chem. Biol. Drug Des. 2011, 78 (6), 1014-1021.

24. Hancock, R.; Bertrand, H. C.; Tsujita, T.; Naz, S.; El-Bakry, A.; Laoruchupong, J.; Hayes, J. D.; Wells, G. Peptide inhibitors of the Keap1-Nrf2 protein-protein interaction. Free Radic. Biol. Med. 2012, 52 (2), 444-451.

25. Lu, M. C.; Jiao, Q.; Liu, T.; Tan, S. J.; Zhou, H. S.; You, Q. D.; Jiang, Z. Y. Discovery of a head-to-tail cyclic peptide as the Keap1-Nrf2 protein-protein interaction inhibitor with high cell potency. Eur. J. Med. Chem. 2018, 143, 1578-1589.

26. Jiang, Z. Y.; Lu, M. C.; You, Q. D. Discovery and development of Kelch-like ECH-associated protein 1. nuclear factor erythroid 2-related factor 2 (Keap1:Nrf2) protein-protein interaction inhibitors: achievements, challenges, and future directions. J. Med. Chem. 2016, 59 (24), 10837-10858. 
27. Davies, T. G.; Wixted, W. E.; Coyle, J. E.; Griffiths-Jones, C.; Hearn, K.; McMenamin, R.; Norton, D.; Rich, S. J.; Richardson, C.; Saxty, G.; Willems, H. M.; Woolford, A. J.; Cottom, J. E.; Kou, J. P.; Yonchuk, J. G.; Feldser, H. G.; Sanchez, Y.; Foley, J. P.; Bolognese, B. J.; Logan, G.; Podolin, P. L.; Yan, H.; Callahan, J. F.; Heightman, T. D.; Kerns, J. K. Monoacidic inhibitors of the Kelch-like ECH-associated protein 1: nuclear factor erythroid 2-related factor 2 (Keap1:Nrf2) protein-protein interaction with high cell potency identified by fragment-based discovery. J. Med. Chem. 2016, 59 (8), 3991-4006.

28. Inoyama, D.; Chen, Y.; Huang, X.; Beamer, L. J.; Kong, A.-N. T.; Hu, L. Optimization of fluorescently labeled Nrf2 peptide probes and the development of a fluorescence polarization assay for the discovery of inhibitors of Keap1-Nrf2 interaction. J. Biomol. Screen. 2012, 17 (4), 435-447.

29. Hu, L.; Magesh, S.; Chen, L.; Wang, L.; Lewis, T. A.; Chen, Y.; Khodier, C.; Inoyama, D.; Beamer, L. J.; Emge, T. J.; Shen, J.; Kerrigan, J. E.; Kong, A. N.; Dandapani, S.; Palmer, M.; Schreiber, S. L.; Munoz, B. Discovery of a small-molecule inhibitor and cellular probe of Keap1-Nrf2 protein-protein interaction. Bioorg. Med. Chem. Lett. 2013, 23 (10), 3039-3043.

30. Jnoff, E.; Albrecht, C.; Barker, J. J.; Barker, O.; Beaumont, E.; Bromidge, S.; Brookfield, F.; Brooks, M.; Bubert, C.; Ceska, T.; Corden, V.; Dawson, G.; Duclos, S.; Fryatt, T.; Genicot, C.; Jigorel, E.; Kwong, J.; Maghames, R.; Mushi, I.; Pike, R.; Sands, Z. A.; Smith, M. A.; Stimson, C. C.; Courade, J. P. Binding mode and structure-activity relationships around direct inhibitors of the Nrf2-Keap1 complex. ChemMedChem 2014, 9 (4), 699-705.

31. Bresciani, A.; Missineo, A.; Gallo, M.; Cerretani, M.; Fezzardi, P.; Tomei, L.; Cicero, D. O.; Altamura, S.; Santoprete, A.; Ingenito, R.; Bianchi, E.; Pacifici, R.; Dominguez, C.; Munoz-Sanjuan, I.; Harper, S.; Toledo-Sherman, L.; Park, L. C. Nuclear factor (erythroid-derived 2)-like 2 (Nrf2) drug discovery: biochemical toolbox to develop Nrf2 activators by reversible binding of Kelch-like ECH-associated protein 1 (Keap1). Arch. Biochem. Biophys. 2017, 631, 31-41. 
32. PubChem bioassay record AID 651829 belonging to the assay project "Broad Institute HTS Fluorescence Polarization Assay for Inhibitors of Keap1-Nrf2 Interaction Inhibitor Probe Project". https://pubchem.ncbi.nlm.nih.gov/assay/651829 (accessed on Apr. 6, 2019)

33. Marcotte, D.; Zeng, W.; Hus, J. C.; McKenzie, A.; Hession, C.; Jin, P.; Bergeron, C.; Lugovskoy, A.; Enyedy, I.; Cuervo, H.; Wang, D.; Atmanene, C.; Roecklin, D.; Vecchi, M.; Vivat, V.; Kraemer, J.; Winkler, D.; Hong, V.; Chao, J.; Lukashev, M.; Silvian, L. Small molecules inhibit the interaction of Nrf2 and the Keap1 Kelch domain through a non-covalent mechanism. Bioorg. Med. Chem. 2013, 21 (14), 4011-4019.

34. Jain, A. D.; Potteti, H.; Richardson, B. G.; Kingsley, L.; Luciano, J. P.; Ryuzoji, A. F.; Lee, H.; Krunic, A.; Mesecar, A. D.; Reddy, S. P.; Moore, T. W. Probing the structural requirements of non-electrophilic naphthalene-based Nrf2 activators. Eur. J. Med. Chem. 2015, 103, 252-268.

35. Zhuang, C.; Narayanapillai, S.; Zhang, W.; Sham, Y. Y.; Xing, C. Rapid identification of Keap1-Nrf2 small-molecule inhibitors through structure-based virtual screening and hit-based substructure search. J. Med. Chem. 2014, 57 (3), 1121-1126.

36. Winkel, A. F.; Engel, C. K.; Margerie, D.; Kannt, A.; Szillat, H.; Glombik, H.; Kallus, C.; Ruf, S.; Gussregen, S.; Riedel, J.; Herling, A. W.; von Knethen, A.; Weigert, A.; Brune, B.; Schmoll, D. Characterization of RA839, a noncovalent small molecule binder to Keap1 and selective activator of Nrf2 signaling. J. Biol. Chem. 2015, 290 (47), 28446-28455.

37. Szill, H.; Ruf, S.; Glombik, H.; Kallus, C.; Engel, K.-C.; Guessregen, S.; Schmoll, D.; Kannt, A.; Dudda, A.; Monecke, P.; Elshorst, B. Naphthyl Sulfonamide Pyrrolidine Derivatives as KEAP-1 Modulators for the Treatment of Diabetes, Obesity, Dyslipidemia and Related Disorders. European Application no. 14306430.1, 2016.

38. Yasuda, D.; Yuasa, A.; Obata, R.; Nakajima, M.; Takahashi, K.; Ohe, T.; Ichimura, Y.; Komatsu, M.; Yamamoto, M.; Imamura, R.; Kojima, H.; Okabe, T.; Nagano, T.; Mashino, T. Discovery of benzo[g]indoles as a novel class of non-covalent Keap1-Nrf2 protein-protein interaction inhibitor. Bioorg. Med. Chem. Lett. 2017, 27 (22), 5006-5009. 
39. Callahan, J. F.; Kerns, J. K.; Li, T.; Mccleland, B. W.; Nie, H.; Pero, J. E.; Davies, T. G.; Heightman, T. D.; Griffiths-Jones, C. M.; Howard, S.; Norton, D.; Verdonk, M. L.; Woolford, A. J.-A. Arylcyclohexyl Pyrazoles as Nrf2 Regulators. Application no. PCT/IB2016/055997, 2017.

40. Bertrand, H. C.; Schaap, M.; Baird, L.; Georgakopoulos, N. D.; Fowkes, A.; Thiollier, C.; Kachi, H.; Dinkova-Kostova, A. T.; Wells, G. Design, synthesis, and evaluation of triazole derivatives that induce Nrf2 dependent gene products and inhibit the Keap1-Nrf2 protein-protein Interaction. J. Med. Chem. 2015, 58 (18), 7186-7194.

41. Kazantsev, A. G.; Thompson, L. M.; Abagyan, R.; Casale, M. Small Molecule Activators of Nrf2 Pathway. Application no. PCT/US2014/041335, 2014.

42. Satoh, M.; Saburi, H.; Tanaka, T.; Matsuura, Y.; Naitow, H.; Shimozono, R.; Yamamoto, N.; Inoue, H.; Nakamura, N.; Yoshizawa, Y.; Aoki, T.; Tanimura, R.; Kunishima, N. Multiple binding modes of a small molecule to human Keap1 revealed by X-ray crystallography and molecular dynamics simulation. FEBS Open Bio $2015,5,557-570$.

43. Shimozono, R.; Asaoka, Y.; Yoshizawa, Y.; Aoki, T.; Noda, H.; Yamada, M.; Kaino, M.; Mochizuki, H. Nrf2 activators attenuate the progression of nonalcoholic steatohepatitis-related fibrosis in a dietary rat model. Mol. Pharmacol. 2013, 84 (1), 62-70.

44. Xu, L. L.; Zhu, J. F.; Xu, X. L.; Zhu, J.; Li, L.; Xi, M. Y.; Jiang, Z. Y.; Zhang, M. Y.; Liu, F.; Lu, M. C.; Bao, Q. C.; Li, Q.; Zhang, C.; Wei, J. L.; Zhang, X. J.; Zhang, L. S.; You, Q. D.; Sun, H. P. Discovery and modification of in vivo active Nrf2 activators with 1,2,4-oxadiazole core: hits identification and structure-activity relationship study. J. Med. Chem. 2015, 58 (14), 5419-5436.

45. Ghorab, M. M.; Alsaid, M. S.; El-Gazzar, M. G.; Higgins, M.; Dinkova-Kostova, A. T.; Shahat, A. A. Synthesis and biological evaluation of novel 2-phenylquinazoline-4-amine derivatives: identification of 6phenyl-8H-benzo[g]quinazolino[4,3-b]quinazolin-8-one as a highly potent inducer of $\mathrm{NAD}(\mathrm{P}) \mathrm{H}$ quinone oxidoreductase 1. J. Enzyme Inhib. Med. Chem. 2016, 31 (1), 34-39. 
46. Sun, H.-P.; Jiang, Z.-Y.; Zhang, M.-Y.; Lu, M.-C.; Yang, T.-T.; Pan, Y.; Huang, H.-Z.; Zhang, X.-J.; You, Q.-d. Novel protein-protein interaction inhibitor of Nrf2-Keap1 discovered by structure-based virtual screening. MedChemComm 2014, 5 (1), 93-98.

47. Wager, T. T.; Chandrasekaran, R. Y.; Hou, X.; Troutman, M. D.; Verhoest, P. R.; Villalobos, A.; Will, Y. Defining desirable central nervous system drug space through the alignment of molecular properties, in vitro ADME, and safety attributes. ACS Chem. Neurosci. 2010, 1 (6), 420-434.

48. Rankovic, Z. CNS physicochemical property space shaped by a diverse set of molecules with experimentally determined exposure in the mouse brain. J. Med. Chem. 2017, 60 (14), 5943-5954.

49. Bergman, R. G.; Danheiser, R. L. Reproducibility in chemical research. Angew. Chem. Int. Ed. Engl. 2016, 55 (41), 12548-12549.

50. Prinz, F.; Schlange, T.; Asadullah, K. Believe it or not: how much can we rely on published data on potential drug targets? Nat. Rev. Drug Discov. 2011, 10 (9).

51. Flier, J. S. Irreproducibility of published bioscience research: diagnosis, pathogenesis and therapy. Mol. Metab. 2017, 6 (1), 2-9.

52. Baell, J. B.; Holloway, G. A. New substructure filters for removal of pan assay interference compounds (PAINS) from screening libraries and for their exclusion in bioassays. J. Med. Chem. 2010, 53 (7), 2719-2740.

53. Baell, J. B.; Walters, M. A. Chemical con artists foil drug discovery. Nature 2014, 513 (7519), 481-483.

54. Baell, J. B.; Nissink, J. W. M. Seven year itch: pan-assay interference compounds (PAINS) in 2017utility and limitations. ACS Chem. Biol. 2018, 13 (1), 36-44.

55. Hu, L.; Magesh, S.; Chen, L.; Lewis, T.; Munoz, B.; Wang, L. Direct Inhibitors of Keap1-Nrf2 Interaction as Antioxidant Inflammation Modulators. U.S. Application. No. PCT/US2012/06833, 2013.

56. Yasuda, D.; Nakajima, M.; Yuasa, A.; Obata, R.; Takahashi, K.; Ohe, T.; Ichimura, Y.; Komatsu, M.; Yamamoto, M.; Imamura, R.; Kojima, H.; Okabe, T.; Nagano, T.; Mashino, T. Synthesis of Keap1phosphorylated p62 and Keap1-Nrf2 protein-protein interaction inhibitors and their inhibitory activity. Bioorg. Med. Chem. Lett. 2016, 26 (24), 5956-5959. 
57. Callahan, J. F.; Kerns, J. K.; Li, P.; Li, T.; Mccleland, B. W.; Nie, H.; Pero, J. E.; Davies, T. G.; Grazia Carr, M.; Griffiths-Jones, C. M.; Heightman, T. D.; Norton, D.; Verdonk, M. L.; Woolford, A. J.-A.; Willems, H. M. G. Biaryl Pyrazoles as Nrf2 Regulators. Application no. PCT/IB2016/055996, 2017.

58. East, D. A.; Fagiani, F.; Crosby, J.; Georgakopoulos, N. D.; Bertrand, H.; Schaap, M.; Fowkes, A.; Wells, G.; Campanella, M. PMI: a DeltaPsim independent pharmacological regulator of mitophagy. Chem. Biol. 2014, 21 (11), 1585-1596.

59. Fang, W.-P.; Cheng, Y.-T.; Cheng, Y.-R.; Cherng, Y.-J. Synthesis of substituted uracils by the reactions of halouracils with selenium, sulfur, oxygen and nitrogen nucleophiles under focused microwave irradiation. Tetrahedron 2005, 61 (12), 3107-3113.

60. Hirota, K.; Watanabe, K. A.; Fox, J. J. Pyrimidines. 14. novel pyrimidine to pyrimidine transformation reactions and their application to C-nucleoside conversion. a facile synthesis of pseudoisocytidine. J. Org. Chem. 1978, 43 (6), 1193-1197.

61. Milroy, L. G.; Grossmann, T. N.; Hennig, S.; Brunsveld, L.; Ottmann, C. Modulators of protein-protein interactions. Chem. Rev. 2014, 114 (9), 4695-4748.

62. Meng, N.; Tang, H.; Zhang, H.; Jiang, C.; Su, L.; Min, X.; Zhang, W.; Zhang, H.; Miao, Z.; Zhang, W.; Zhuang, C. Fragment-growing guided design of Keap1-Nrf2 protein-protein interaction inhibitors for targeting myocarditis. Free Radic. Biol. Med. 2018, 117, 228-237.

63. Simeonov, A.; Jadhav, A.; Thomas, C. J.; Wang, Y.; Huang, R.; Southall, N. T.; Shinn, P.; Smith, J.; Austin, C. P.; Auld, D. S.; Inglese, J. Fluorescence spectroscopic profiling of compound libraries. J. Med. Chem. 2008, 51 (8), 2363-2371.

64. Turek-Etienne, T. C.; Lei, M.; Terracciano, J. S.; Langsdorf, E. F.; Bryant, R. W.; Hart, R. F.; Horan, A. C. Use of red-shifted dyes in a fluorescence polarization AKT kinase assay for detection of biological activity in natural product extracts. J. Biomol. Screen. 2004, 9 (1), 52-61. 
65. Nikolovska-Coleska, Z.; Wang, R.; Fang, X.; Pan, H.; Tomita, Y.; Li, P.; Roller, P. P.; Krajewski, K.; Saito, N. G.; Stuckey, J. A.; Wang, S. Development and optimization of a binding assay for the XIAP BIR3 domain using fluorescence polarization. Anal. Biochem. 2004, 332 (2), 261-273.

66. Niesen, F. H.; Berglund, H.; Vedadi, M. The use of differential scanning fluorimetry to detect ligand interactions that promote protein stability. Nat. Protoc. 2007, 2 (9), 2212-2221.

67. Holdgate, G. A.; Ward, W. H. J. Measurements of binding thermodynamics in drug discovery. Drug Discov. Today 2005, 10 (22), 1543-1550.

68. Matulis, D.; Kranz, J. K.; Salemme, F. R.; Todd, M. J. Thermodynamic stability of carbonic anhydrase: measurements of binding affinity and stoichiometry using ThermoFluor. Biochemistry 2005, 44 (13), 52585266.

69. Quinn, J. G. Evaluation of Taylor dispersion injections: determining kinetic/affinity interaction constants and diffusion coefficients in label-free biosensing. Anal. Biochem. 2012, 421 (2), 401-410.

70. Quinn, J. G. Modeling Taylor dispersion injections: determination of kinetic/affinity interaction constants and diffusion coefficients in label-free biosensing. Anal Biochem 2012, 421 (2), 391-400.

71. Zhang, Y.; Talalay, P.; Cho, C. G.; Posner, G. H. A major inducer of anticarcinogenic protective enzymes from broccoli: isolation and elucidation of structure. Proc. Natl. Acad. Sci. U.S.A. 1992, 89 (6), 2399-2403.

72. Bryan, H. K.; Olayanju, A.; Goldring, C. E.; Park, B. K. The Nrf2 cell defence pathway: Keap1-dependent and -independent mechanisms of regulation. Biochem. Pharmacol. 2013, 85 (6), 705-717

73. Thorne, N.; Shen, M.; Lea, W. A.; Simeonov, A.; Lovell, S.; Auld, D. S.; Inglese, J. Firefly luciferase in chemical biology: a compendium of inhibitors, mechanistic evaluation of chemotypes, and suggested use as a reporter. Chem. Biol. 2012, 19 (8), 1060-1072.

74. Sameshima, T.; Miyahisa, I.; Yamasaki, S.; Gotou, M.; Kobayashi, T.; Sakamoto, J. High-throughput quantitative intrinsic thiol reactivity evaluation using a fluorescence-based competitive endpoint assay. SLAS Discov. 2017, 22 (9), 1168-1174. 
75. Dahlin, J. L.; Nissink, J. W.; Strasser, J. M.; Francis, S.; Higgins, L.; Zhou, H.; Zhang, Z.; Walters, M. A., PAINS in the assay: chemical mechanisms of assay interference and promiscuous enzymatic inhibition observed during a sulfhydryl-scavenging HTS. J Med Chem 2015, 58 (5), 2091-2113.

76. Marino, S. M.; Gladyshev, V. N. Analysis and functional prediction of reactive cysteine residues. J. Biol. Chem. 2012, 287 (7), 4419-4425.

77. Netto, L. E.; de Oliveira, M. A.; Monteiro, G.; Demasi, A. P.; Cussiol, J. R.; Discola, K. F.; Demasi, M.; Silva, G. M.; Alves, S. V.; Faria, V. G.; Horta, B. B. Reactive cysteine in proteins: protein folding, antioxidant defense, redox signaling and more. Comp. Biochem. Physiol. C Toxicol. Pharmacol. 2007, 146 (1-2), 180-193.

78. Davis, B. J.; Erlanson, D. A. Learning from our mistakes: the 'unknown knowns' in fragment screening. Bioorg. Med. Chem. Lett. 2013, 23 (10), 2844-2852.

79. Baell, J. B. Redox-active nuisance screening compounds and their classification. Drug Discov. Today 2011, 16 (17-18), 840-841.

80. Johnston, P. A. Redox cycling compounds generate H2O2 in HTS buffers containing strong reducing reagents--real hits or promiscuous artifacts? Curr. Opin. Chem. Biol. 2011, 15 (1), 174-182.

81. Johnston, P. A.; Soares, K. M.; Shinde, S. N.; Foster, C. A.; Shun, T. Y.; Takyi, H. K.; Wipf, P.; Lazo, J. S. Development of a 384-well colorimetric assay to quantify hydrogen peroxide generated by the redox cycling of compounds in the presence of reducing agents. Assay Drug Dev. Technol. 2008, 6 (4), 505-518.

82. Irwin, J. J.; Duan, D.; Torosyan, H.; Doak, A. K.; Ziebart, K. T.; Sterling, T.; Tumanian, G.; Shoichet, B. K. An aggregation advisor for ligand discovery. J. Med. Chem. 2015, 58 (17), 7076-7087.

83. Feng, B. Y.; Shoichet, B. K. A detergent-based assay for the detection of promiscuous inhibitors. Nat. Protoc. 2006, 1 (2), 550-553.

84. Seidler, J.; McGovern, S. L.; Doman, T. N.; Shoichet, B. K. Identification and prediction of promiscuous aggregating inhibitors among known drugs. J. Med. Chem. 2003, 46 (21), 4477-4486.

85. Morrissy, S.; Strom, J.; Purdom-Dickinson, S.; Chen, Q. M. NAD(P)H:quinone oxidoreductase 1 is induced by progesterone in cardiomyocytes. Cardiovasc. Toxicol. 2012, 12 (2), 108-114. 
86. Richardson, B. G.; Jain, A. D.; Potteti, H. R.; Lazzara, P. R.; David, B. P.; Tamatam, C. R.; Choma, E.; Skowron, K.; Dye, K.; Siddiqui, Z.; Wang, Y. T.; Krunic, A.; Reddy, S. P.; Moore, T. W. Replacement of a naphthalene scaffold in Kelch-like ECH-associated protein 1 (Keap1)/nuclear factor (erythroid-derived 2)-like 2 (Nrf2) inhibitors. J. Med. Chem. 2018, 61 (17), 8029-8047.

87. Converso, A.; Hartingh, T.; Garbaccio, R. M.; Tasber, E.; Rickert, K.; Fraley, M. E.; Yan, Y.; Kreatsoulas, C.; Stirdivant, S.; Drakas, B.; Walsh, E. S.; Hamilton, K.; Buser, C. A.; Mao, X.; Abrams, M. T.; Beck, S. C.; Tao, W.; Lobell, R.; Sepp-Lorenzino, L.; Zugay-Murphy, J.; Sardana, V.; Munshi, S. K.; JezequelSur, S. M.; Zuck, P. D.; Hartman, G. D. Development of thioquinazolinones, allosteric Chk1 kinase inhibitors. Bioorg. Med. Chem. Lett. 2009, 19 (4), 1240-1244.

88. Stephen, T.; Stephen, H. 806. Syntheses in the quinazolone series. Part II. Synthesis of quino- and quinazo-quinazolones. J. Chem. Soc. 1956, 0, 4173-4177.

89. Vajpayee, V.; Moon, M. E.; Lee, S.; Ravikumar, S.; Kim, H.; Ahn, B.; Choi, S.; Hong, S. H.; Chi, K.-W. Halogenation and DNA cleavage via thermally stable arenediazonium camphorsulfonate salts. Tetrahedron 2013, 69 (16), 3511-3517.

90. Yang, J.; Shen, Y.; Chen, F. X. Highly efficient $\mathrm{Cs}_{2} \mathrm{CO}_{3}$-catalyzed 1,4-addition of $\mathrm{Me}_{3} \mathrm{SiCN}$ to enones with water as the additive. Synthesis 2010, 8, 1325-1333.

91. Pick, T.; Barsanti, P.; Iwanowicz, E.; Fantl, W.; Hendryckson, T.; Knapp, M.; Meritt, H.; Voliva, C.; Wiesmann, M.; Xin, X. Pyrimidine Derivatives Used as PI-3 Kinase Inhibitors. Application no. PCT/US2007/001708, 2007.

92. Yang, L.; Bao, X.-P. Synthesis of novel 1,2,4-triazole derivatives containing the quinazolinylpiperidinyl moiety and $\mathrm{N}$-(substituted phenyl)acetamide group as efficient bactericides against the phytopathogenic bacterium Xanthomonas oryzae pv. oryzae. RSC Adv. 2017, 7 (54), 34005-34011.

93. Alexandre, F.-R.; Berecibar, A.; Wrigglesworth, R.; Besson, T., Novel series of 8H-quinazolino[4,3b]quinazolin-8-ones via two Niementowski condensations. Tetrahedron 2003, 59 (9), 1413-1419. 
94. Bach, A.; Chi, C. N.; Olsen, T. B.; Pedersen, S. W.; Røder, M. U.; Pang, G. F.; Clausen, R. P.; Jemth, P.; Strømgaard, K. Modified peptides as potent inhibitors of the postsynaptic density-95/N-methyl-D-aspartate receptor interaction. J. Med. Chem. 2008, 51 (20), 6450-6459.

95. Bach, A.; Chi, C. N.; Pang, G. F.; Olsen, L.; Kristensen, A. S.; Jemth, P.; Strømgaard, K. Design and synthesis of highly potent and plasma-stable dimeric inhibitors of the PSD-95-NMDA receptor interaction. Angew. Chem. Int. Ed. Engl. 2009, 48 (51), 9685-9689.

96. Bach, A.; Clausen, B. H.; Møller, M.; Vestergaard, B.; Chi, C. N.; Round, A.; Sørensen, P. L.; Nissen, K. B.; Kastrup, J. S.; Gajhede, M.; Jemth, P.; Kristensen, A. S.; Lundström, P.; Lambertsen, K. L.; Strømgaard, K. A high-affinity, dimeric inhibitor of PSD-95 bivalently interacts with PDZ1-2 and protects against ischemic brain damage. Proc. Natl. Acad. Sci. U.S.A. 2012, 109 (9), 3317-3322.

97. Fahey, J. W.; Dinkova-Kostova, A. T.; Stephenson, K. K.; Talalay, P. The "Prochaska" microtiter plate bioassay for inducers of NQO1. Methods Enzymol. 2004, 382, 243-258. 
Table of Contents graphic

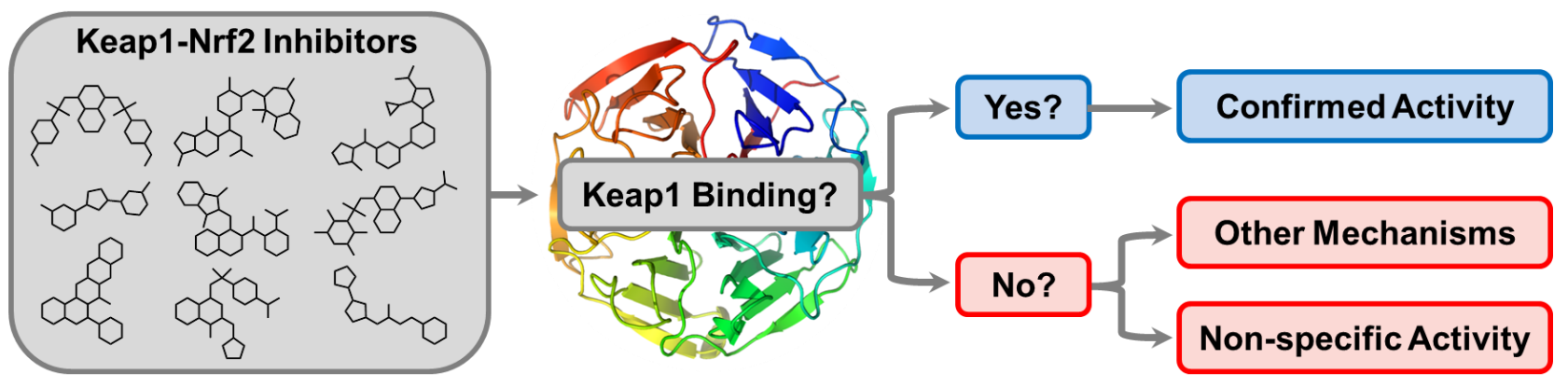

